

|

\$B 96 833

AGRICULTURAL

BACTERIOLOGX

RUSSELL \& HASTINGS 


\section{DOT 31910}







\section{AGRICULTURAL}

\section{BACTERIOLOGY}

BY

H. L. RUSSELL

Dean of the College of Agriculture

UNIVERSITY OF WISCONSIN

AND

E. G. HASTINGS

Associate Professor of Agricultural Bacteriology

UNIVERSITY OF WISCONSIN



MADISON, WISCONSIN

H. L. RUSSELL

1909 


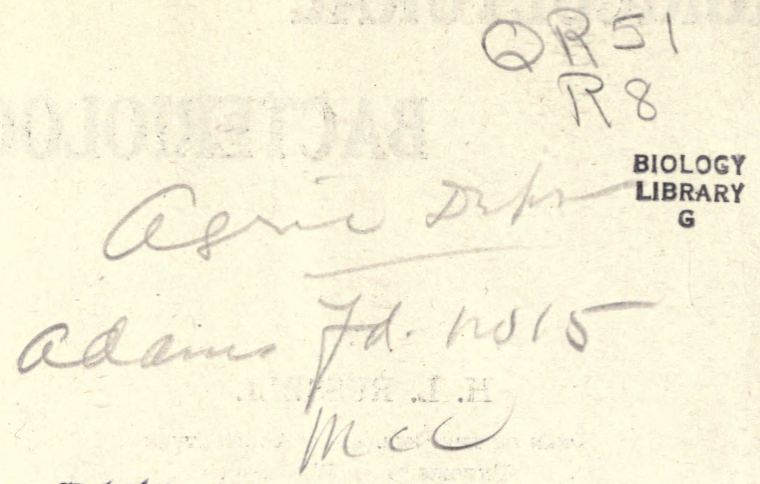

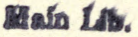 Agric. Dept.}

Copyright, 1909

BY

H. L. RUSSELL and E. G. HASTINGS. 


\section{FOREWORD.}

No single line of discovery has exerted a more profound influence on the scientific thought of the last few decades than has the development of bacteriology. The researches of Pasteur, Koch, and their successors, opened a field of inquiry that has not only revolutionized all of the biological sciences, but also the applied lines of thought. Medicine was the first of these sciences to receive the impetus from such discoveries, but it is no less true that they exert an equally profound effect on agricultural sciences. Too long has agriculture been considered simply an art-a vocation which one had to learn wholly in the school of experience, but the serious student of farm life finds it necessary to understand the phenomena of the plant and animal world and to combat or utilize successfully the activities of various microscopic organisms. It is therefore essential, even in a practical course, that this important subject be properly considered. The text here presented deals with the subject briefly, but it is designed to give a comprehensive treatment of the different relations which the bacteria bear to problems of farm life. At best, it can only serve to stimulate the interest of the student to pursue this subject more in detail as opportunity permits. 




\section{CONTENTS}

\section{SECTION I \\ General Bacteriology}

Chapter I Structure, Growth, and Distribution of Bacteria. 1

II Artificial Cultivation of Bacteria.......... 15

SECTION II

Relation of Bacteria to Milk and other Dairy Products

Chapter III Contamination of Milk............... 22

IV Preservation of Milk............... 44

V Fermentations of Milk................ 53

VI Relation of Bacteria to Butter........... 65

VII Relation of Bacteria to Cheese............ 73

VIII Relation of Bacteria to Market Milk....... 82

SECTION III

Relation of Bacteria to Disease

Chapter IX Transmissible Diseases............... 92

X Anthrax, Black Leg, Hemorrhagic Septicaemia, and Corn Stalk Disease.............. 98

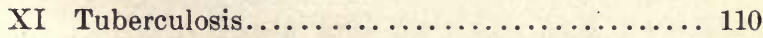

XII Glanders and Tetanus................. 127

XIII Rabies.......................... 134

XIV Actinomycosis, Garget, Cow Pox, and Contagious Garget...................... 142





XVII Miscellaneous Diseases.................. 161






\section{SECTION IV}

\section{Relation of Bacteria to Solls}

Chapter XIX Relation of Bacteria to Fertility........... 171

XX Effect of Bacteria on Minerals of the Soil.... 183

XXI Ammonification, Nitrification, and Denitrification ...................... 186

XXII Fixation of Nitrogen ................. 195

XXIII Bacteria in Manures.................. 207

XXIV Water Supply and Sewage Disposal........ 214

\section{SECTION V}

Food Preservation and Diseases of Plants

Chapter XXV Preservation of Foods................ 225

XXVI Diseases of Plants.................. 235 


\section{SECTION 1. \\ GENERAL BACTERIOLOGY.}

CHAPTER I.

\section{STRUCTURE, GROWTH AND DISTRIBUTION.}

Nature of the bacteria. The bacteria belong to the group of plants known as fungi. The fungus plants do not contain the green coloring matter found in ordinary plants. They live on dead or living animal or vegetable matter. Many of the fungi are well known to the farmer and are of great economic importance causing, as they do, such plant diseases as the rusts, smuts and mildews. Other examples of fungi are the various kinds of molds, toadstools and mushrooms. These are more familiar as they are large enough to be seen by the unaided eye, while many other kinds of fungi and especially the bacteria are unfamiliar objects because by the unaided eye an individual plant can not be seen. When massed together in large numbers they become visible but such groupings are rarely found in nature.

While the bacteria, themselves, are not familiar objects the effect they produce is very evident in the souring of milk, the spoiling of meat and eggs, the production of diseases in plants and animals, and in many other ways which are not so readily recognized.

Knowledge relating to the bacteria has nearly all been gained within the last thirty years although the bacteria were first seen by a Dutch lens-maker, Antoni van Leeuwenhoek, in 1675. For nearly two hundred years after they were first discovered but little of importance was learned concerning them. 
Structure of bacteria. Plants and animals are made up of cells which are tiny masses of semi-liquid matter surrounded by a membrane, the cell wall. Many kinds of cells are found in each individual higher plant or animal. The sum total of the activities of all the cells constitutes the life of the individual. Bacteria are made of cells the same as other living things, but instead of a number of cells being required to form an individual, each cell is a complete organism in itself, capable of carrying on all the processes necessary for the continuance of its life. The single cell can breathe, take in food, live, and reproduce itself. Thus while the bacteria are very simple as to their structure, they perform all the necessary functions of a living organism.



$\boldsymbol{A}$

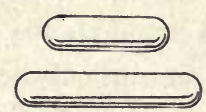

B

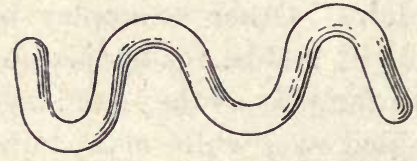

C

Fig. 1.-Forms of Bacteria.

A, coccus; B, bacillus; C, spirillum. (After Novy.)

Forms of bacteria. Where the individual is reduced to the limits of a single cell, it is evident that not much variation in form is possible. While slight variations in size and shape are to be noted, nearly all the bacteria may be grouped under three general types. The ballshaped are known as cocei (singular coccus); the rodshaped are called bacilli (singular bacillus); if the rods instead of being straight are more or less eurved, they are known as spirilla (singular spirillum). The ballshaped and the rod-shaped are by far the most abundant and are the forms of most interest to the student of agricultural bacteriology. 
Size of bacteria. All of the bacteria are so small they can not be seen by the unaided eye. In fact their minuteness is such as to render difficult any adequate conception of their size. In a single teaspoonful of sour cream ready for the churn, there are often $1,500,000,000$ becteria. The teaspoonful of cream is not nore crowded than is our world with the $1,500,000,000$ people living on its surface. In the drop of cream each organism is living its own life and doing a certain amount of work as is each person on the surface of the globe.

The different kinds of bacteria vary considerably in relative size. The largest may be several hundred times as large as the smallest forms. Even with the largest, one hundred or more laid side by side would not equal in thickness an ordinary sheet of paper.

Manner of reproduction. Most of the ordinary plants increase in number by forming seeds. The seed germinates and grows into a plant which may produce thousands of seeds similar to the one planted. Many kinds of fungus plants reproduce by the formation of spores, which in some ways are analogous to the seeds of the higher plants. The cloud of smoke from the ripe puffball is made up of its tiny spores. The ripe smut on the corn owes its black color to the multitude of spores it contains.

In their manner of reproduction the bacteria are to be compared to the individual cell of the higher plant or animal rather than to the entire plant. The germi. nating corn plant is made up of a number of cells. These divide each into two, these two cells again divide to form four cells and so on, the plant, meanwhile, in- 
creasing in size. The bacteria increase in number in a similar way, each cell dividing into two at each division. The mother cell disappears and two daughter cells are
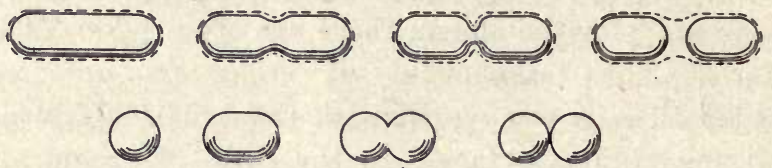

Fiǵ. 2.-Division of Bacteria.

The bacteria increase in numbers through the division of each cell into two cells. (After Novy.)

formed, which in turn soon become mother cells and thus the process is repeated.

Arrangement of cells. Each kind of plant can be recognized because the cells forming it are arranged in a certain definite way, different from the arrangement of the cells in all other plants. The arrangement of the cells of those kinds of bacteria that cling together after the cell has divided often enables the experienced bac-



A



C

Fra. 3.-Arrangement of Bacteria.

A, streptococci; B, sarcina; C, staphylococci. (After Novy.)

teriologist to recognize different types. The cells may be arranged in long or short chains. Such aggregates of cocci are known as streptococci ; clusters of cocci resembling bunches of grapes are called staphylococci. Still other forms of cocci divide in such a manner as 
to form packets of cells resembling a bale of binder twine (sarcina), while many forms show no regularity in the grouping of the cells. But few of the bacilli and spirilla show a characteristic grouping of the cells.

Spores of bacteria. The seeds of plants are not so easily injured by heat, cold, or drying as are the growing plants which bear them. The seeds thus earry over the plant from one growing season to the next. Many kinds of bacteria form within the cell a tiny structure, called a spore, which is much more resistant than the vegetating cell, and hence, in this respect is comparable


Fig. 4.-Spore Formation and Germination.

Figures on upper line show various stages of spore development. Lower left hand figure represents the cell issuing from the spore case.

to the seeds of ordinary plants. The spores are, however, much more resistant than the seeds of any of the higher plants. Boiling for hours will not kill some kinds of bacterial spores. They can be dried for years and still grow quickly when placed in a favorable foodmaterial. Thus, the bacteria forming spores are able to withstand unfavorable environmental conditions.

The spores are unlike seeds in that spore formation is not to be considered as a manner of increasing in 
numbers since one cell forms but a single spore, and germination this spore grows into a single cell. N all bacteria form spores, a very fortunate circumstan as will be seen later. The resistant spores often gi to the dairyman and farmer a great amount of trouble

Movement of bacteria. Plants as a rule do not mov yet some of our common plants can move their leave as the ordinary sensitive plant. Many water plan possess organs of locomotion. Certain of the bacter are able to move in the liquids in which they exis This motion is accomplished by the lashing to and fr of the fine hair-like processes known as cilia. Tl movement of the bacteria is really very slow althoug when a drop of a liquid containing motile bacteria seen under the microscope, the bacteria seem to be mo ing rapidly about, for their motion is magnified in th same manner as are the bacteria themselves.

Food supply of bacteria. The green plant lives 0 certain inorganic substances in the soil. The colorles group of plants to which the bacteria belong, the fung live on living or on dead animal and vegetable matte By far the majority of the bacteria find most favorabl conditions for growth on dead organic matter. The cause the spoiling of our food-stuffs and are largely r sponsible for the complete disappearance of the anim: and vegetable matter that reaches the soil. They ar thus of the utmost importance for without them th earth would soon be encumbered with the dead bodie of plants and animals. To consume this organic mat ter is the function of the class of bacteria known as th saprophytic bacteria. The bacteria that, under natura conditions, live only in the bodies of living plants an 
animals are called parasitic bacteria. To the latter group belong those especially important forms, the pathogenic bacteria, which produce the transmissible diseases of plants and animals. Some species ordinarily learl a saprophytic life in the soil, but may, if accident introduces them into the bodies of animals, grow and produce serious trouble. These forms are not to be looked upon as parasites since their natural habitat is not the body of a living animal.

The saprophytic as also the parasitic bacteria vary widely as to the kind of food best adapted to their different needs. Some kinds of parasitic bacteria grow only in the body of man, others only in certain animals, while still other types grow in the bodies of a large number of different kinds of animals. Some of the soil bacteria grow only on certain kinds of food substances, while others flourish on the widest variety of materials.

Condition of the food. Since the food must be absorbed by the bacterial cell before it can be used, it is necessary that it be in solution. Some forms of bacteria are able to develop digesting substances, known as enzymes, by means of which they render insoluble material soluble, utilizing the same in part as food.

Bacteria can not, as a rule, grow well in acid substances, a fact which is widely applied in the preservation of human and animal foods. In this respect they differ from most of the fungi which thrive preferably on acid rather than on neutral or alkaline substances. Tellies and plant juices, therefore, spoil from mold development while blood and animal products as broths and soups undergo bacterial decomposition.

Oxygen supply of bacteria. Every living thing, even every living cell of the growing plant or animal, must 
have air, or rather oxygen. The bacteria are no exception to this rule. Many forms known as aerobes (living in the air) can grow only in the presence of oxygen. A smaller group known as anaerobes (living without air) grow only in the total absence of free oxygen. These forms must, however, have oxygen, but their only available source is the combined oxygen which they se-



Fig. 5.-Photomicrograph of Anthrax Bacilli.

The chain-like arrangement is characteristic of this organism. Each member of the chain is an individual bacillus. Magnified 1,000 diameters.

cure from organic substances like sugar. An intermediate type is able to live and grow under either condition, i. e., in the presence or absence of free oxygen. These are called facultative anaerobes.

Moisture supply of bacteria. No cell growth of any kind can take place without moisture. Bacterial changes go on most rapidly in the presence of an abun- 
dant supply of moisture. Foods, such as meats, fruits, vegetables and also fodders are protected from the action of bacteria and molds by drying. Molds require much less moisture for their growth than do the bacteria.

Temperature for the growth of bacteria. In common with other forms of plant life, bacterial growth oceurs throughout a relatively wide temperature zone; in fact, wider than in the case of most other plant forms. Most forms of bacteria are checked in their growth when the temperature approximates $40^{\circ}-45^{\circ} \mathrm{F}$. although a few of them thrive near the freezing point. At ordinary air temperatures, multiplication of the cells proceeds apace as is shown by the decomposition of organic substances. During hot summer weather, $80^{\circ}-100^{\circ} \mathrm{F}$., decomposition is still further hastened. If, however, the temperature is increased much above the blood heat, growth of most forms is checked. A temperature of $130^{\circ}-140^{\circ} \mathrm{F}$. actually kills most of the vegetating bacteria. To exceed this fatal point, known as the thermal death point, is the basis of all methods of preservation of foods by heat.

Rate of growth of bacteria. When a suitable food is available and temperature conditions are favorable, the bacteria increase in numbers very rapidly. A single organism will divide, and the two daughter cells grow to maturity, ready to divide again, in twenty minutes or less. This rate of growth rarely takes place under natural conditions and is never maintained for any considerable length of time for most forms of life encounter conditions in nature that restrict their development. 
Food is not always abundant, the temperature may be such as to limit or even stop growth. Every living thing has its enemies. These limitations check bacterial growth in the same manner as all the higher forms of life are checked.

Under artificial conditions the bacteria may grow very rapidly for a time. For instance, it has been shown that a single organism when placed under the most favorable conditions as to food and temperature will increase in ten hours to the enormous number of 1,240,000,000. This rapid growth does not continue, but, on the other hand, goes on more and more slowly and at last ceases altogether, because the products formed by the organisms themselves accumulate and make further growth impossible. Every form of life living on plant or animal matter may be killed by its own excretions unless they are removed. The bacteria are no exception to this rule.

Effect of cold on bacteria. Low temperatures retard the rate of growth of the bacteria. The exact point at which growth ceases varies widely with different species. Some forms as the organism eausing tuberculosis will not grow below $90^{\circ} \mathrm{F}$. Still others will grow at temperatures below freezing when they are present in a liquid like brine that does not freeze. When the substance in which the bacteria are present becomes solid by freezing, growth must cease but the bacteria are not necessarily killed. For example water bacteria are not all killed by freezing although it is popularly supposed that water purifies itself in this manner. Even diseaseproducing bacteria may resist this degree of cold for $a$ 
number of months. For this reason ice used in cooling drinking water should come only from uncontaminated sources.

Effect of heat on bacteria. All forms of life are destroyel by high temperatures. The seeds of the higher plants are not so easily killed by heat as are the plants themselves and in the same way the spores formed by certain of the bacteria are very difficult to kill. Some must be subjected to the temperature of boiling water $\left(212^{\circ} \mathrm{F}\right.$.) for hours in order to destroy them.

Two forms of heat are used to destroy bacteria, moist heat, as steam or hot water, and dry heat as produced in an oven. As every one knows, one can place his hand in an oven heated much above $212^{\circ} \mathrm{F}$. without injury, but the same exposure to steam or boiling water would result in a serious burn. The effect on the bacteria is the same. For this reason when it is desired to destroy germ life on or in any substance, moist heat is: preferably used if it will not injure the object.

Effect of light on bacteria. All the plants which contain the green coloring matter, chlorophyll, can produce a normal growth only in the presence of light. Fungi grow rapidly in the dark. To some of the fungi the light is not especially injurious. The bacteria, especially the pathogenic bacteria, even in a spore stage, are easily killed by direct sunlight. As previously stated, the spores are very difficult to kill by heating, much more so than the vegetating cell, but sunlight. kills the spores of most forms almost as quickly as it does the growing cell.

While the direct sunlight is very efficient in destroying both cells and spores, the diffused light of an ordi- 
nary house or barn has but little effect. Where the bacteria are covered by dust or dirt light has no effect.

Effect of chemicals on bacteria. Many chemical substances are poisonous to plants and animals. When such substances exert a peculiarly marked effect on germ life they are known as disinfectants or germicides. Corrosive sublimate, earbolic acid, and formaldehyde are the best known and strongest lisinfectants. When present in very small amounts they do not kill the bacterial cells but may prevent their growth. Some chemicals, even in strong solutions, are not poisonous enough to kill the bacteria but may merely check the growth. Such are known as antiseptics or preservatives. All disinfectants in a dilute form have an antiseptic action, but not all antiseptics, even in concentrated solutions, are disinfectants. For example, lime is an antiseptic, since it dissolves in water to such an extent as to prevent all growth of bacteria, but it does not kill many forms of bacteria. Acids, such as vinegar, are antiseptics, and are constantly used in the preservation of human and animal foods.

Products formed by bacteria. When the bacteria grow in any food-substance, parts of the same are consumed. As a result of this growth, the bacteria give of from their bodies various kinds of by-products that are very different from the original food-substance. The changes that take place in any substance in which the bacteria are growing are collectively known as "fermentations." Many kinds of by-products are formel by the various forms of bacteria, such as the acids produced in the souring of milk, and in the change of ciler to vinegar, also in the "working" of canned fruits and 
vegetables. Alkalies, as ammonia, may be produced as in the fermentation of urine in the horse stable. Highly poisonous substances are sometimes formed in the bodies of animals by the disease-producing bacteria.

Distribution of bacteria. Bacteria are more universally distributed than any other form of life. They be. come very abundant where conditions for growth are suitable, particularly where a fitting supply of food is: fcund. The soil is teeming with germ life, for the dead tissues of both plant and animal life find their way to the soil. As most of this material is found in the upper part of the soil, the bacteria are naturally more abundant here than in the subsoil. Some of the kinds occurring in the soil are quite indispensable to the life of higher plants, since they aid in the preparation of the food for plants.

Next to the soil, the intestinal canal of animals support a large and varied bacterial flora. The blood, the different internal organs such as the liver and spleen, or the muscles contain few or no bacteria, but in the alimentary tract from the mouth to the rectum, bacteria are found in varying numbers.

Water is also to be looked upon as one of the natural habitats of bacteria, for it always contains food substances in greater or less abundance. As a rule the number of bacteria in water depends on the relation of the water to the soil. Surface streams usually contain many bacteria, especially when the water from cultivated fields drains into the stream. In shallow wells that receive the drainage from the upper layers of the soil, bacteria also abound. As the water percolates through the soil the bacteria are filtered out, hence, the water from deep wells contains very few. The number 
found in the waters of rivers, especially those of considerable size, and in lakes is usually small since there are many factors that tend to destroy the bacteria.

Most of the other places in which the bacteria are found are not to be looked upon as natural habitats, but rather as secondary sources. The bacteria may be found almost anywhere, because dust from the soil finds its way into or onto every objeet. The bacteria of the air come from the soil, being carried up by air currents. The number in the air depends on the amount of dust present; hence, in cities many are found in the air, in the open country far less, and in the air over large bodies of water, none may be present.

The bacteria found in all articles of food come from one of the natural habitats of this form of life. By keeping foods as clean as possible a great deal can be done to preserve them. 


\section{CHAPTER II.}

\section{ARTIFICIAL CULTIVATION OF BACTERIA.}

The bacteria are so small that many thousands of them must be present in a mass before they can be seen with the naked eye. The necessity of having masses of bacteria of the same kind for study in the laboratory thus becomes evident, and since such masses do not occur in nature it becomes necessary to grow them artifieially.

Food substances. The substances used in the laboratory upon which the bacteria can be grown are of animal or vegetable origin. These bacterial foods or "culture media," as they are technically called, may be prepared from various vegetables, as potatoes or beets. Broths made from meat or beef-extract are constantly employed, as are milk, coagulated egg, and blood-serum. The composition of these natural media are often modified through the addition of various qualifying substances, such as sugar, peptone, and glycerine, in order to make them more suitable for the growth of certain kinds of bacteria.

All culture media when prepared from ordinary materials contain more or less baeterial life, because of the presence of the organisms in the ingredients themselves, and due to the inevitable contamination during the process of manufacture.

If the culture media are to be kept for any length of time they must be freed from all living bacteria and 
kept so. For this purpose the various media are placed in glass vessels, such as flasks and tubes, which are stoppered with cotton-wool. This cotton plug allows: the air to pass freely in and out of the vessel, but removes all dust and bacteria that the air may contain. It serves to prevent the bacteria from entering the vessel from the outside as effectively as though the vessel were sealed air tight.

Sterilization. After the media is thus protected from future contamination, the contained bacteria are killed by heating the media to the boiling point for a short time on each of three successive days. The vegetating cells are easily killed but the spores are not destroyed by the first heating. If the media is stored at ordinary temperatures, many of the spores will germinate and form cells before the second heating. The remaining spores will usually sprout by the third day and are then destroyed. A heating treatment applied as preseribed will usually render any food medium "sterile," i. e., absolutely free from all living bacteria or their spores. When so treated it. will keep for an indefinite period if protected from drying.

The vegetating cells and also the spores may be killed at one heating but the exposure must be very prolonged or it must be made in a closed chamber in which steam is generated. In this latter condition the temperaturecan be raised quickly to a point considerably higher than the boiling point so that the spores will be killed in a few minutes. This same process is used in the canning of vegetables, such as corn and peas. All such foods must be sterile or they will soon spoil.

The containers used to hold the media are usually of glass and are rendered free from all living bacteria by 
heating them in a hot-air oven. This method can not be used for culture media since it would burn the same.

Determination of the number of bacteria in substances. The extreme minuteness of the bacteria makes it impossible to count them individually. To determine the number present in any material it is necessary to



Fig 6.-Plate Cuidure.

Each of the dots is a colony that has been formed by the growth of a bacterial cell embedded in the solid medium. By counting the colonies, the number of bacteria in the material examined is determined.

separate each organism from all others by an appreciable distance. The organisms are then placed in an appropriate food substance in which they are held in place, growth occurs and a mass large enough to be 
seen by the naked eye is soon obtained. If, for example, the number of bacteria in a sample of water is to be determined, the conditions mentioned above are obtained in the following way. A definite amount of water is intimately mixed with a small amount of beefbroth to which gelatin has been added. This furnishes a medium which is solid at ordinary temperatures, but which can be easily melted, and by cooling changed back to a solid again. If the gelatin is at once cooled after the water has been mixed with it, the bacterial cells will be held in place in the now solid medium. The gelatin is then placed under favorable conditions for the growth of the bacteria. The cells begin to increase in number, and as their progeny can not move away, the resulting mass of cells soon becomes large enough to be recognized by the unaided eye. In liquid media, such as beef-broth, the bacteria are not held in place and the liquid becomes uniformly turbid because of the distribution of the bacteria in it.

Each of the masses of growth, technically called a "colony," is the progeny of a single cell. Thus, if the colonies are counted, the result will be the number of bacterial cells present in the substance at the time the cultures were made. In order to make the counting of the colonies easy the mixture of gelatin and water is placed in a shallow glass dish so as to form a thin layer of solid gelatin on the bottom of the dish. It is protected from the bacteria of the air by a glass cover.

It is essential if one is to determine how many bacteria are present in the amount of water used, that each of the colonies on the culture plate is the result of the growth of an organism present in the water. This necessitates that the food medium, the glass dish and 
everything coming in contact with the culture in any way is wholly free from living bacteria, i. e., sterile.

Many substances frequently contain so many bacteria that it is impossible to add a small enough amount to the gelatine directly, and not have the cultures so thickly dotted with colonies that it would be impossible to count them. To overcome this difficulty a small but definite amount of the substance is added to a definite amount of sterile water, and intimately mixed. A quantity of the mixture is then added to the melted gelatin. In this manner it is possible to obtain 1-1000 of a drop of water or milk, a procedure that will be seen to be necessary when it is known how many of the bacteria there may be in a drop of these liquids.

Pure cultures of bacteria. Since each colony has resulted from the growth of a single cell, it follows that all of the cells of the colony are of the same kind. If a small bit of the mass of growth is transferred from the original colony to a tube of fresh food, the resulting growth is known as a "pure culture." If some other form of bacteria should accidentally fall into the tube from the air when the tube is opened, the culture no longer contains a single kind but a mixture and is now called an impure or mixed culture.

The shape and appearance of the colonies of the different kinds of bacteria differ as do their growth on various media. These differences often aid the experienced bacteriologist in determining the kind of bacteria in the materials examined.

In order to separate a pure culture from a mixture of many kinds or in order to determine the kinds of bacteria present in any substance, essentially the same method is used as described above. 
Use of the microscope. The mieroscope of necessity is a tool of vital importance to the bacteriologist. The extreme minuteness of the bacteria require that an instrument magnifying several hundred diameters be used. Even then the bacteria in an untreated condition are very difficult to see on account of their transparency. In order to make them more easily visible a very small amount of the substance in which they are growing is spread on a thin piece of glass and allowed to become perfectly dry. The organisms are then killed by heating gently and are treated with various stains which impart a bright color, red, blue, or purple as the case may be, to the bacteria. Just as a red glass is seen more easily than a piece of perfect plate glass so the stained bacteria are more easily seen than the unstained forms, and, moreover their size, exact form and other characteristics are more easily determined.

Appearance of the bacteria under the microscope. The appearance of the individual bacterial cell under the microscope can not vary widely because of the limitation that the bacteria are one-celled structures. The spherical forms always appear as tiny dots, the rods as dashes, and the spiral forms as dashes or lines more or less curved in various ways. The size varies somewhat, as do the arrangement of the cells with reference to each other, but the microscope rarely enables one to tell the kind of bacteria present in a culture. The appearance of the growth on a large number of media must be noted, as also the changes produced in these different food substances. These serve as aids to the appearance under the microscope in determining the kind of bacteria one has at hand. 
Handling of bacteria. The bacteria are handled in the laboratory and are transferred from one culture tube to another containing fresh food by means of small platinum wires inserted in glass handles. These wires are rendered germ free by heating them in a flame before they are used. By keeping the culture tubes plugged with cotton, by careful use of the inoculating needle, and by using care at every step, the bacteriologist works with the most dangerous disease-producing organisms without danger to himself.

Use of experimental animals. In the study of the disease-producing or pathogenic bacteria, it frequently becomes necessary to use for inoculation purposes small animals, such as guinea pigs, rabbits, white mice, and rats. Some forms of bacteria can not grow on any of the artificial media but may develop in the bodies of animals, so that animal inoculation becomes a necessity in determining whether any particular kind of organism is able to produce disease or not.

Incubation of bacteria. Many of the bacteria have acquired parasitic properties and grow naturally only in the bodies of animals. Such is the ease with the tubercle bacillus. If such types are to be artificially propagated, the cultures must be kept under conditions simulating the animal body. Hence incubators to maintain the cultures at the same temperature as the animal body are more or less essential in bacteriological work. 
SECTION II.

\section{RELATION OF BACTERIA TO MILK AND OTHER DAIRY PRODUCTS.}

\section{CHAPTER III.}

\section{CONTAMINATION OF MILK.}

A large part of the farming population of the country is actively interested in the production of milk. Every one is interested in milk from the food standpoint. How this important food product ean be produced under clean and healthful conditions therefore appeals to every one, producer and consumer alike.

Milk a perishable food. Milk is produced on the farm, (1) for sale in the towns and cities, (2) for use in the manufacture of butter and cheese. In order that it shall find a ready market in the city and that the butter and cheese made from it shall be of the highest quality, it is necessary that the milk be produced and handled under improved conditions. No other food is produced under circumstances that permit of the introduction of such an amount of dirt and bacteria as are found very frequently in milk. At every step it is neeessary to consider the relation of bacteria to this food product. Many of the most important human foods are perishable. Eggs, meat, many fruits, and vegeta- 
bles rapidly undergo changes that render them undesirable, or even unfit for human food. Milk is the most perishable food of all. Produced under ordinary con. ditions and with no precautions taken to preserve it during the warmer periods of the year, it is unfit for use in twenty-four hours.

There are two reasons for this rapid deterioration:(1) gross contamination, (2) its nature and composition. The surroundings in which milk is produced always make infection easy. The high nutritive composition and the dilution of its food ingredients make it admirably adapted as a medium for bacterial growth. Many of the bacteria produce changes in the milk which injure the quality of the butter and cheese. It thus becomes important to prevent as far as possible the introduction of the bacteria and to check their development in the milk.

Contamination of milk. In order to prevent the bacteria from getting into the milk, it is necessary to know the sources from which they come, and to become acquainted with practical means of exclusion. Unless the sources are recognized and something is known of their relative importance, numerous things will be done that are unnecessary, and often the essential things left undone.

The subject of the contamination of milk is the most important and fundamental one in dairy bacteriology. At every step in the production of milk and in its treatment on the farm the farmer is confronted with this subject. The returns he receives from his milk are often decided by the wisdom with which he meets the problems concerned in the production of clean and healthiful milk. 
The contamination of milk must be considered from. two points of view:-(1) the economic, that is the contamination with those forms of bacteria that cause the milk to sour, (2) the hygienic, the contamination with those forms of bacteria that produce disease in human beings. Both of these phases of milk contamination are becoming more important each year, as more is learned of the ways in which diseases are spread and as the rapid growth of the cities makes it necessary to draw milk from more distant sources.

Condition of milk when formed in the udder. When the milk is secreted in the udder of a healthy cow it is sterile. The various internal organs and the blood are practically sterile in healthy animals, hence any substance which is formed from the blood must be sterile.

Condition of the milk when drawn from the udder. If a sample of milk is drawh into a sterile vessel in such a way as to prevent all external contamination, it will be found to contain a greater or less number of bacteria, which must have come from the udder of the animal.

The udder is composed of the secreting tissue held in place by the fibrous connective tissue. From the upper part of the glandular secreting tissue, small tubes lead downward, joining each other until they communicate with a small cavity known as the milk cistern, which holds about one half-pint. From this cistern the milk flows into the teat which is guarded by muscles, at the top and bottom. A normal contraction of these muscles keeps the milk from leaking out of the udder.

The end of the teat inevitably becomes soiled with material containing bacteria. Through the opening of 
the teat the bacteria make their way up into the milk cistern and to a less extent into the milk ducts, and even to the secreting tissue proper. Many forms un. doubtedly enter but only a few are able to grow to any cxtent. They are harmless guests and cause the cow no trouble. They are found in the milk when it is drawn, usually several hundred in every cubic centimeter. Since the bacteria enter the udder through the teat, one should expect to find the greater number in the lower part of the udder, where they would be washed out during the first part of the milking. As a rule the first streams from each teat contain a larger number of organisms than those subsequently drawn.

This source of contamination can not be wholly avoided. Material reduction in numbers may be produced by excluding the fore-milk $i$. e., the first few streams drawn from each teat. Such milk should be drawn into a separate container, not milked on to the floor. It may be used for feed. It is always low in butter fat. While such a method will reduce the number of bacteria in the milk slightly, it has no particular effect upon the keeping quality of the milk since the organisms found in the udder grow very slowly at ordinary temperatures and produce no marked changes in the milk.

Some times the udder is invaded by harmful kinds of bacteria which grow rapidly and cause an inflammation of the gland, which diseased condition is known as gar. get. See p. 144.

Contamination from the animal. Milking is almost always carried on under conditions, that must be called unclean when it is considered that human food is being prepared. Conditions are tolerated in the barn that 
would not be allowed in the kitchen, and yet, in both cases the preparation of human food is in progress. Of necessity it is difficult to produce milk in a wholly clean environment; yet every effort should be made to improve the barn conditions as much as possible.

During the milking, dust, dirt, and manure particles are dislodged from the udder and flanks of the animal by the motions of the milker. These particles inevitably fall into the open pail. The amount of dirt and manure thus introduced into the milk depends almost entirely on the cleanliness of the animal. If the flanks and udder are coated with manure and dried mud, a very large amount of dirt will enter the milk and nothing can prevent it.

As has been previously mentioned a prominent source of bacterial life is the intestinal canal of animals. In the manure are found an immense number of bacteria. It requires but a small amount of manure to add many thousands of bacteria to every drop of milk. The fact that the kinds of bacteria derived from the manure produce, in the main, injurious changes in the milk (bad odors and tastes) affecting not only the milk but the butter and cheese as well, makes it highly desirable to reduce the contamination from this source as far as possible.

The dust from the skin of the animal contains large numbers of bacteria. Esten found in the dust taken from a curry comb 207,000,000 organisms per gram (1-30 ounce). The hairs, even those from the cleanest cows, have large numbers of bacteria on them.

Prevention of contamination from the animal. In order to prevent the milk from being contaminated with large quantities of mud and manure, the animal must be 
kept clean. The cows must not have access to mud holes, the yards should be so arranged that they can not become muddy during the wet times of the year.

The arrangement of the stalls should be such as to prevent contact of the body of the animal with the manure. This can only be accomplished by using a manure drop, i. e. a deep gutter. The animal can also. be kept clean by the use of a stall that requires her to stand well to the rear and forces her forward when lying down. Many of the patented stalls seek to accom-



- Fig. 7.-The Model Stall.

A stall of this type keeps the animals clean and aids greatly in the production of clean milk.

plish this in a variety of ways. Fig. 7 represents a stall that accomplishes this purpose in a most successful way. The essential feature of this stall is the placing of a two by three inch piece of timber across the floor of the stall. This piece is so placed that when the animal stands with her head close to the slatted manger, it will be just in front of her hind feet. Thus when the animal 
is standing, her hind feet will always be back of the strip and the manure fall well to the rear. The animal soon learns that it is not at all comfortable to lie on the strip and thus crowds to the front on lying down and is out of contact with the manure. The clean condition of the cows in the accompanying illustration is to be noted. The photographs were taken in the early spring before the cows had shed their winter coats. Less than one hour per day of one man's time was spent in cleaning the thirty animals of the herd. A stall that accomplishes this purpose, together with plenty of clean bedding is all that is needed to keep the cattle clean. These things are within the reach of every farmer. Concrete is often used as a floor and is very desirable on account of the easier cleaning. It is desirable, especially in the colder parts of the country, to cover the concrete of the stalls with wood.

Other things may be done that will greatly reduce the contamination from the animal. The long hairs should be clipped from the udder and flanks and the tail should also be clipped. The short hair holds much less dirt and the animal can be cleaned much easier in case she becomes soiled. Cleaning with card and brush will also insure the removal of much of the loose dirt and hair from the skin. This treatment should be given some time before the milking time, on account of the dust produced. The udder and flanks should be wiped with a damp cloth just before milking. This serves to remove much of the dust and prevents the dislodgment of the finer dust particles during the milking process.

Improved milk pails. In order to still further diminish the contamination from the animal the use of a pail 
with a small opening is desirable. The larger part of the dirt entering the pail comes from the flank rather than from the udder. The dirt is dislodged by the contact between the milker and the flank of the animal. All this material finds its way into the common large topped pail. If the opening is restricted to six inches, the exposed surface is greatly lessened. A six inch opening is one-fourth as large in area as a twelve inch. The reduction of contamination will be in still greater proportion as with the small topped pail the opening is directly beneath the udder during the milking. The dirt from the flanks does not find its way so readily into this pail as it does into the ordinary pail.

Stocking has shown that under ordinary barn conditions the number of bacteria found in milk drawn into such a covered pail was but five per cent of the number found when an ordinary pail was used, and with very dirty cows but 3 per cent.

Many forms of pails of this character have been suggested. All seek to reduce the size of the opening in one way or another. Some of the most practical forms are represented in Figs. 8 and 9. In some of the pails, strainers of cloth or cotton are used, although brass wire gauze is effective and easier cleaned.

The use of the milking machine avoids a large part of the contamination from the animal since the milk is drawn directly into a closed tube through which it passes to the receiving can.

Contamination from utensils. The various utensils used in handling milk always contain bacteria, the number depending on the cleanliness of the utensils, which is determined (1) by the manner of washing, (2) the construction of the utensil, (3) the condition of the 
utensil. Cheap tin-ware is usually made with folded seams which are not flushed with solder. The milk penetrates into the crevices thus formed and can not
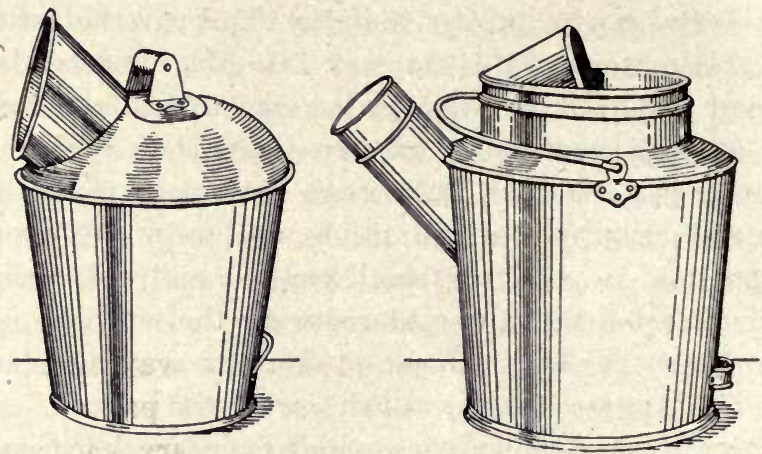

Fig. 8.- Imiroved Milk Pails.

The small opening is very efficient in keeping dirt out of the milk.
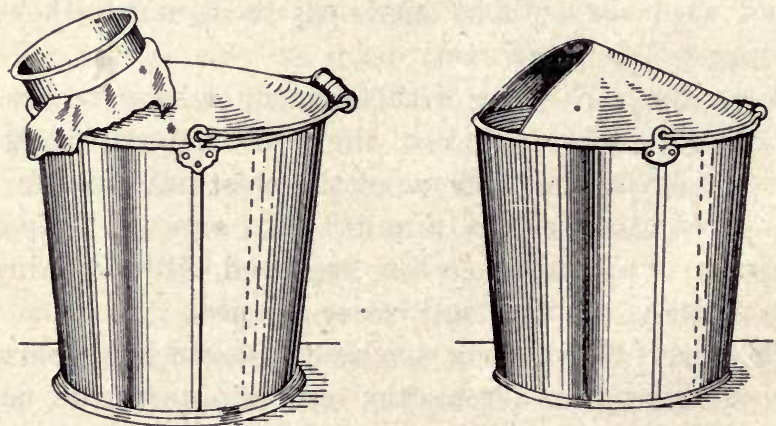

Fig. 9.-Improved Mirk Pails.

The Stadtmueller pail and the Truman pall, two of the most practicable of the small topped pails.

be removed by washing. As the utensil becomes older the seams become more and more open and a greater amount of material accumulates in them to find its way into the milk. Old battered and rusty tin-ware can not 
be well cleaned by washing unless the facilities for such purposes are much better than on the ordinary farm.

All tin-ware should have a smooth and unbroken surface. Even the roughness due to the accumulation of the white layer (milk stone) on the pails and cans renders them much more difficult to wash and hence increases the contamination from them. Pressed tinware is preferable but if the utensils are made with seams the depressions should be thoronghly flushed with solder.

The farm cream-separator is a utensil that needs especial care. Often it is not the custom to take the machine apart after each period of use and wash it thoroughly. When used for the evening milk it is often only rinsed out by passing water through the bowl. The slime that accumulates on the wall of the bowl can not be removed in this way, and between the periods of use, especially during warm weather, the bacteria grow rapidly in the slime. When milk is passed through the separator in the morning, a large part of these bacteria find their way into the milk and cream and may cause undesirable fermentation changes in them. The separator should be taken apart, well washed and scalded after each period of use. Much loss is caused to the farmers of the country due to the diminished returns received from butter made from cream separated in dirty farm separators. In fact, it is well recognized that the general introduction of the farm separator has led to a deterioration in the quality of butter.

Contamination from factory by-products. The farmer is accustomed to return to the farm the skim milk or whey from creamery or factory in the milk can. If the can is at once emptied and thoroughly washed, no 
especial harm results. In the whey, especially in that from unclean tanks, are found injurious forms of bacteria that find their way from the whey to the cheese vat through the medium of the contaminated and poorly washed milk ean. In order to avoid this source of loss a separate set of cans should be used in which to return. the by-products to the farm. At some eheese factories. and creameries the by-products are heated to the scalding point before being returned to the farm. When so. handled the results are essentially as good as if a separate set of cans were used.

Washing milk utensils. All milk utensils should be washed as soon as possible after using, for if the milk is allowed to dry on the surface of such containers it is very difficult to remove. They should be rinsed with cool or luke-warm water, then thoroughly washed with a hot solution of a washing powder, as Wyandotte or a similar preparation, using, preferably, a stiff brush for scrubbing. The use of soap and soap powders is to be avoided for they are difficult to remove by rinsing and are not as effective in the removal of the milk and grease. The utensils should be well rinsed in boiling water, using a large quantity, so that they will be thoroughly scalded. If the scalding is done with a small amount of hot but not boiling water, the bacteria on the walls of the utensils will not be destroyed. After scalding they should be drained but never wiped. If sufficient hot water is used, the utensil will be heated. so that it will dry quickly with no further attention. The clean utensils should be stored in a place free from dust.

Wherever steam is available, the eleansing ean bemade much more effective by steaming, after rinsing 
with clean water. By this treatment it is possible to destroy practically all bacteria. For this reason most city dairy companies and even some cheese-factories and creameries wash the cans of their patrons. Where steam is not available the utensils may be immersed in boiling water. Some such treatment is especially recommended to the milk producer supplying milk to the city market.

The milk producer who uses a milking machine avoids one source of contamination only to meet another unless care is taken in the handling of the machine. The rubber tubes used in connection with the machine are very difficult to clean. They should be well rinsed after use and at once placed in a 3 per cent formaldehyde solution in such a way that the entire tube will be filled with the solution. This will prevent all growth of bacteria in the tubes. If some such treatment is not given the tubes, the milk drawn by the machine will be found to contain more bacteria than that drawn by hand. This is due to the fact that it is impossible to remove all of the milk from the tubes by rinsing them, and since it is also impossible to dry the inside of the tubes, conditions are favorable for bacterial growth with the result that, when the tubes are next used, the bacteria pass into the milk. The milking machine is an aid in the production of clean milk only when used in an intelligent and careful manner.

Contamination from the air. In the barn air more or less dust is to be found, coming from the feed, bedding, and dried manure. The dust particles act as floats for the bacteria, and when the dust settles into the milk pail, the milk is contaminated with bacteria. The barn air should contain the minimum of dust at milking 
time. This condition is to be obtained by not feeding hay or other rough, dry fodder shortly before milking, by not carrying on any dust-producing operations as bedding, sweeping, etc., just before milking. The ceilings of the stable should be tight so that dust and dirt can not fall from the floor above and the walls and ceilings should be free from cobwebs.

The stable should be of such construction as to be easily kept clean. Abundant light should be provided, because the same is beneficial to the cattle and renders evident dirty conditions. Abundant ventilation means less dust in the barn air and hence fewer bacteria to fall into the milk.

Contamination from the milker. The milker is to be looked upon as an important factor in milk contamination. His habits with reference to personal cleanliness mirror themselves in the amount of dirt he will get into the milk drawn by him. The hands of the milker should be clean, for some milk is certain to come in contact with them on its way to the pail. The suit which is worn during milking should be kept for that purpose alone and should be washed at frequent intervals.

The milking should always be done with dry hands using the whole hand and stripping with the fingers avoided as far as possible. Vaseline can be used on the hands or on the teats of the cow if desired.

Influence of food on contamination of milk. It is believed by many that the bacteria in the feed or water consumed by the cow pass directly into the milk by way of the udder. From what has been said it is evident that such ean not be the case. The feed may influence the kind of germs in the milk by influencing 
the kind in the manure. Unsavory as it may sound, a large part of the bacteria in the milk have their origin in the manure, which, in one way or another, is added to the milk.

If spoiled or wet feeds such as brewery or distillery slops are fed, intestinal troubles may result with a change in the kind of bacteria found in the manure. Only in this way can the feed influence, in any considerable way, the bacterial content of the milk. Moldy and dusty feeds should not be used. The straw used for bedding should be clean. Horse manure should not be used for bedding in the cow stalls. If the feed is such as to render the manure very thin, it is much more difficult to keep the animals clean, thus influencing the number of micro-organisms found in the milk. The in: fluence of impure water is due usually to the fact that the cattle have access to a stream or pond. By wading about in the water their udders are soiled, and at milking some of the water bacteria get into the milk.

Absorption of odors. Milk absorbs many but not all odors very easily and for this reason it should be kept in a place free from all pronounced odors of any kind. The odors of certain fruits, as bananas, and the odor of strong silage are quickly absorbed by milk. It is a popular belief that milk will not absorb odors when it is warmer than the surrounding air, but experimentally it can be easily demonstrated that the opposite is true, the warm milk absorbing the odors more rapidly than the cold. For this reason milk should always be removed from the stable as soon as it is drawn from the animal, for in the stable there is quite certain to be some odor arising fro' $\mathrm{n}$ the manure, the animals themselves, or the feed. The danger of thus tainting the 
milk is much less in a well ventilated stable. Milk should never be strained, aerated or separated in the stable.

Odors absorbed from the feed. In certain feeds such as turnips, cabbage, rape, and in many weeds are found substances that give to the various plants their characteristic taste and odor. If a milch cow is fed on such plants, the peculiar flavoring substance will pass through the system and reappear in the milk, often giving to the milk such a peculiar taste as to render it useless for direct consumption or for butter and cheese making. Such feeds should never be fed except in limited quantities immediately after milking so that the volatile odors may be eliminated from the body before the next milking. Green rye and strong silage should be fed with care or the milk will be injured.

The milk from cows receiving medicine in any form should be excluded from the supply since many drugs pass from the body tissues to the milk. Such milk may cause illness, especially in children, and injure the quality of butter and cheese.

The constituent of milk that causes it to absorb odors so readily is the fat. Butter is more easily injured by absorption of 'odors than is milk, as is not infrequently noted when it is kept in an ice-box with fruits, etc. If the milk is tainted, the butter and cheese are very certain to show the same flavor. This can be demonstrated by feeding cows on rape and making cheese from the milk. The ripe cheese will possess the flavor of rape to such an extent as to be worthless.

Contamination under winter and summer conditions. It is often thought that the milk produced in summer is much cleaner than the winter milk. This is less true 
than is usually believed, for on too many farms the cattle have access to places where they become soiled with mud. The number of bacteria gaining entrance to the milk in the summer may be as great as in winter. The udder comes in contact with the ground when the animal lies down in the pasture or in the yard. The dust thus accumulated is not especially visible, but its load of bacteria reaches the milk.

The milk house. The room in which the milk is to be strained and cooled, preferably, should not be in the barn, but at a short distance from it. It should be far enough away so that the odors of the barnyard will not be present. The room should be provided with a concrete floor, with abundant light and good ventilation. The windows and doors should be well screened so that flies may not have access to milk and the utensils. As will be seen later flies are often carriers of diseaseproducing bacteria.

Clean milk. The demand for clean milk is increasing rapidly. It is desired not only because it keeps longer, tastes better, and finer butter and cheese can be made from it, but also because dirty milk means sickness and death to the children, not so much to the children of the country, for these drink fresh milk only a few hours old before the bacteria carried into the milk in dust, mud and manure have had a chance to grow and thus injure the milk. But the city child consumes milk which is at least a day old and very often two or three days old, in which the bacteria have developed to an enormous extent. Clean milk is desired for cleanliness sake. Every one wishes his food prepared and handled in a clean manner. Manure in milk is no more to be tolerated than it is in bread, and it is no more 
necessary that it be present in the former than in the latter.

Essentials in the production of clean milk. The statement is frequently made that the production of clean milk means expensive stables, elaborate equipment, and much expenditure of time and labor, but such ideas are far from correct. The essential conditions are (1) clean cows, clean because they are not allowed to lie in their own excreta, or are not forced to wade in muddy yards; (2) clean utensils, well washed and sterilized; (3) clean barns; (4) clean men who take pleasure in keeping their stables and animals clean, and who recognize the important sources of contamination of milk and avoid them, while omitting the nonessential things that figure so largely in many of the directions for the production of clean milk.

The expense of producing clean milk need be but slightly more than that involved in the production of the ordinary grade of milk. The same animals, the same feed, the same time spent in feeding and in caring for the cattle, supplemented by a slight amount of attention directed to the important points is all that is needed.

Infection of milk with disease-producing bacteria. Milk is often a means by which disease is spread. It may serve to convey the disease-producing germs from one animal to another, from the cow to man, or from one person to another in the case of some diseases not found in the cow. Of the diseases common to man and cattle, tuberculosis is the most important. Of the diseases found only in man but which are spread by means of milk, typhoid fever and diphtheria are of most concern. 
Tuberculosis of the cow. As will be seen in a subsequent chapter, the tubercle germs may be given off from the body of the diseased animal in the "open" stage of the disease. They may come from the lungs, intestines, and udder. Leaving the body from any of these sources they may reach the milk. In tuberculosis of the lungs the cow coughs up material from these organs and swallows it. It is digested, but the tubercle bacteria it contains pass off from the body in the manure. When the disease affects the intestines, the manure also contains the tubercle organisms.

The bacteria are carried into the milk with the manure arfd barn-dust. The udder is often affected by the disease. In this case the milk is certain to contain large numbers of the tubercle organisms, although it may be perfectly normal in appearance and taste.

Milk containing tubercle bacilli is often a means of producing the disease in man, especially is this true in the case of children, who use larger quantities of milk than do adults and who seem to acquire tuberculosis by way of the intestinal tract more easily than dees the adult. If milk containing tubercle bacilli is fed to calves and hogs, they are certain to be infected.

In order to be certain that the milk does not contain ary tubercle bacilli it must have come from healthy animals. Many tuberculous cows may give milk which is perfectly healthful, but sooner or later the milk of such animals is certain to contain the organisms of the disease. No one can tell when this condition obtains, hence the only safe way is to reject all diseased animals from the dairy herd.

Miscellaneous diseases of the cow. Certain other diseases may be acquired by man from cattle through 
the milk. Foot and mouth disease, a common disease of eattle in Germany and France, is often so acquired. Lumpy jaw or actinomycosis may affect the udder and the organisms be given off in the milk. Inflammation of the udder or garget, especially contagious garget, is caused by bacteria that may produce throat and intestinal troubles in man. The milk of any animal which shows any fever in the udder or whose milk is any way abnormal should be kept from the general supply. It may not be harmful, but it is the secretion of a diseased gland and should not be used as human food. The milk of cows having chronic diarrhea, inflammation of the bowels, or that have not cleaned well after calving should be rejected. In short the milk of any animal that is sick or that is receiving medicine should not be used for human food.

Typhoid fever and diphtheria. Typhoid fever is an intestinal disease of human beings. The bacteria are taken into the alimentary tract with food or drink that has been contaminated in some way. The organisms are given off from the body of the patient in the feces and urine. These materials find their way into the sewage which is so frequently discharged into rivers and lakes that also serve as sources of water supply. When privies are used as in the country, the typhoid bacteria may reach the farm well by means of the water percolating from the privy vault through the ground into the well. If such contaminated waters are used to wash milk utensils, the milk may be contaminated with the typhoid fever germs. Milk utensils are frequently rinsed with cold water just previous to using. Some of the bacteria are certain to enter the milk if the water is polluted. 
The contamination of the milk may also occur through the agency of a person acting as a nurse and also handling the milk. The hands of the nurse are easily soiled with the discharges of the patient, particularly the urine which often contains many typhoid bacilli, some of which may thus find their way into the milk. The patient after recovery still gives off typhoid bacteria from his body for a longer or shorter period and thus may serye to contaminate the milk. Such people, known as "typhoid carriers," are one of the most important means of spreading the disease.

The ordinary house fly is one of the most common means of infecting food with the typhoid bacillus. If it has access to any infectious material, it may readily carry the bacilli to the food in the kitchen or to the milk in the barn or milk house. The privy vault should be so arranged that flies can not enter it. The dwelling house and also the milk house should be provided with screens at the doors and windows.

In order to prevent the spread of typhoid fever all discharges from the patients should be thoroughly disinfected. No one who has anything to do with a typhoid patient should have anything to do with the milk in any way directly or indirectly. The patient, after recovery, should not handle dairy products or have anything to do with milk utensils until the consent of a physician is obtained. This should be the invariable practice on the farm, in the cheese-factory, the creamery and in the city milk-depot, for experience has shown that a single case of typhoid has often been the means of infecting the milk supply, thus producing widespread epidemics. There is no danger of trans- 
mission of the disease to stock as none of the domestic animals acquire typhoid fever.

The tubercle germ can not grow in milk, when drawn from the animal; the typhoid bacillus on the other hand is able to grow in it at ordinary temperatures. Only a drop of polluted water or the most minute particle of matter containing typhoid bacteria is necessary to seed the milk. Because of the growth of the bacilli, the milk may contain large numbers of them by the time it reaches the consumer.

The diphtheria bacillus grows in the throat and in the nasal passages of the affected person. The only way in which it can reach the milk is through the medium of the nurse, whose hands may have become contaminated or from the patient after recovery, for unfortunately recovery does not mean that the diphtheria bacillus has disappeared entirely from the throat and nasal passages. They may persist there for months. The diphtheria bacillus like the typhoid organism can grow in milk at ordinary temperatures. The milk from farms on which diphtheria is present should not be sent to the city market. The same rules relative to the patient should be enforced as with typhoid fever.

Scarlet fever is also spread by milk and the same precautions should be observed as in the case of the diseases previously mentioned.

Intestinal troubles caused by milk. During the summer months the death-rate amongst milk-fed children in the cities is very high. This is due, in a large measure, to the intestinal troubles that are occasioned by improper food. Milk on account of its quick perishability is especially liable to produce troubles of this sort. The death-rate of children is greatest among 
the poorer people who are either unable to keep their milk supply in good condition on account of the lack of ice, or who do not appreciate the proper handling of tnis food product.

These troubles are not caused by any specific kinds of bacteria but by many kinds that get into the milk with the dirt and manure. As was previously pointed out, the country child drinks fresh milk, the child of the tenement-house district, old milk. Not the filth, but the bacteria associated with it, are the cause of the trouble. The remedy is clean milk and as fresh as possible to the consumer's door.

Poisoned milk. Occasionally milk is the cause of trouble due to the fact that it contains poisonous compounds formed by bacteria in their development. Normally the acid-forming bacteria prevent the grow.th of the harmful kinds. In ice cream, poisonous products are more often found than in milk, due to the práctice of storing cream during the cooler tirnes of the summer in order to have a supply for the warmer periods. Some forms of bacteria can grow in the milk and cream at the storage temperatures and produce poisonous products. 


\section{CHAPTER IV.}

\section{PRESERVATION OF MILK.}

Necessity for preservative measures. It is impossible to produce milk that does not contain bacteria. Some will be present no matter how much care is exereised since those forms from the interior of the udder can not be avoided. Usually many more are added to the milk during the various processes of handling. If the milk is left to itself, it will very soon be unfit for use. It thus becomes necessary to use some means of preserving the milk. This preservation may be accomplished in a number of ways: (1) by removing the bacteria; (2) by preventing their growth in the milk; (3) by killing the bacteria in the milk. Most frequently a combination of two or all of these methods is empluyed.

Straining of milk. A process carried out on every farm and in every cheese-factory, creamery, and milkdepot is that of straining the milk. This is primarily done to remove the solid particles, such as hair, straw, etc., that have gained entrance to the milk. These substances always have bacteria on their surfaces, hence their removal should reduce the bacterial content of the milk. The number of bacteria removed in this way is small, since the continued use of the strainer for all the milk of the herd or the supply coming to the milkdepot serves to wash most of the bacteria from the solid particles removed by the strainer. 
The mud and manure that enters the milk is partially soluble. Not over one-half of the manure can be removed by a cloth strainer. The dissolving of the dirt and manure allows most of the bacteria to pass into the milk. Straining has practically no effect on the kecping qualities of the milk. It is undoubtedly a legitimate process, although from the standpoint of the consumer in the city or in cheese-factory and creamery much can be said against it, since it serves to make the rnilk appear better than it really is and thus deceives the consumer. The Swiss cheese makers do not allow their patrons to strain the milk because they wish to know its actual state of cleanliness.

Cloth strainers may really be a source of contamination rather than an aid in the removal of bacteria, unless they are carefully washed and boiled at least once a day, and placed where they will dry quickly and thoroughly. The odor that is sometimes noticable in the dish-cloth or the kitchen towel is due to the fact that in the moist cloth there is food enough to allow bacterial growth to take place. In the same manner growth occurs in the milk-strainer for it is almost impossible to remove all traces of the milk by washing. This growth can be prevented and all trouble avoided by boiling the cloth each day in order to sterilize it and by hanging it where it will dry quickly.

Filtering of milk. Filters composed of various materials as paper, cotton, and sand have been employed for the filtering of milk. It was thought that by the use of finer materials than cloth the bacteria would be ramoved more efficiently. The use of these materials has not been very successful. Unless well cleaned after each period of use they soon become sources of 
contamination rather than a means of removing the bacteria. The filtering of milk as a method of removal of bacteria can never be a success since anything that would remove the bacteria would also remove the fat globules as these are larger than the bacteria.

Clarifying of milk. When milk is passed through a cream separator, a slimy mass collects on the wall of the bowl. This material is very high in bacteria. It was urged for many years that the clarifying of the milk was a successful means of removing the bacteria. Although the bacterial content of the slime is very much higher than that of the milk separated, the reduction of the germ content of the milk and cream is irsignificant, because the amount of slime removed is such a small part of the milk separated. The clarification has no effect on the keeping qualities of the milk. The clarification removes more efficiently than straining the insoluble dirt in the milk. Clarified milk shows no sediment on standing and for this reason the process has been adopted by many milk-companies. Irike straining, it makes the milk appear better than it really is and thus misleads the consumer.

It is evident from what has been said that but little can be done in removing the bacteria from milk when once they have gained access. The more successful way to preserve the milk is to prevent the growth of the bacteria. This can be done in a number of ways: (1) by the use of low temperatures, (2) by the use of certain chemicals, which have an antiseptic action, i. e. prevent or retard the growth.

Cooling of milk. The use of low temperatures is the the most widely used and the most efficient means of 
preserving milk. As was previously stated, most forms of bacteria grow best at $70^{\circ}-90^{\circ} \mathrm{F}$. If milk is drawn and no effort made to cool it, the temperature is such as to favor bacterial growth except during the coldest periods of the year and the milk spoils quickly. If the milk is cooled to $50^{\circ} \mathrm{F}$. by the use of cold water, or water and ice, and maintained at this temperature, it will keep several times as long as if uncooled, for the reason that many forms of bacteria do not grow at $50^{\circ} \mathrm{F}$. and all kinds grow slowly.

The cooling should be done immediately after the milk is drawn. It should be done not only in the summer but also in the winter. More trouble is often had with the milk supply in the winter than in the summer, largely because the farmers do not recognize the necessity of cooling the milk during the colder season. A ten gallon can of milk, warm from the cow, requires hours to reach $50^{\circ}$ when placed in a room having a temperature of $40^{\circ}-45^{\circ} \mathrm{F}$. This temperature is rerequired by the city of New York, and the milk must not be above $50^{\circ}$ when it reaches the city. Such regulations are necessary when the milk must be shipped hundreds of miles as is the case with the larger cities. The milk received by the consumer in the large city is often of better quality than that sold in the smaller places, because more attention is paid to cooling the milk and to keeping it cold.

Milk intended for the creamery and cheese factory should be cooled. This is especially true of the evening milk. If the morning milk is to be delivered at once to the cheese factory, it need net be cooled. The bad effects of mixing night and morning milk is due to the raising of the temperature of the night milk by the 
addition of the warm milk. If the morning milk is well cooled before mixing, no bad effects will be noted.

The milk is best cooled by the use of an apparatus such as the Champion or Star coolers. These cool the milk by causing it to run in a thin stream over a metal surface, on the opposite side of which is the cooling agent. The milk may be cooled in tall narrow cans by placing them in cold water, in this case the milk should be stirred at intervals otherwise the cooling goes on very slowly. The best plan is to cool to $55^{\circ}-60^{\circ} \mathrm{F}$. by the use of a cooler, then to set the cans in a vat of ice water. The cooling of milk should be done in a pure air, free from dust and all odors, otherwise the milk is likely to be injured.

Aeration of milk. In the past many claims have been made concerning the benefits to be derived from the acration of milk. It is certain that nearly all the good effects ascribed to aeration are due to the cooling which all processes of aeration produce. If the aera. tion should be carried out with warm air, no beneficial effect would be noted. The gases given off from the milk during the aeration may make the can of milk show a less objectionable odor when opened at the factcry or milk-depot, but it is certain that the quality of the milk is not improved from the standpoint of the consumer and that better cheese can not be made from the aerated milk.

Use of antiseptics in milk. The chemicals most often used to preserve milk are bicarbonate of soda (baking soda), borax, boracic acid, salicylic acid, and formalin. All of the commercial preservatives contain one of these chemicals, usually formalin, since this is the 
cheapest and most efficient. The use of preservatives is prohibited by law in every state and their use, if detected, punishable by fine. Their use is prohibited since these substances are looked upon as injurious to human health. There is not much temptation for the farmer to use them, the city dealer is more tempted, since by their use he can carry over to the next day the surplus milk and economize in the use of ice. One ounce of formalin costing two cents added to 1,000 pounds of milk will cause it to keep for twerity-four to forty-eight hours longer than it otherwise would.

Bicarbonate of soda does not prevent the growth of bacteria, but does, by neutralizing the acid formed, delin the time when the milk begins to taste sour. The remainder of the substances mentioned act by retarding the growth of the bacteria.

Pasteurization of milk. As has been stated, the bacteria, especially the vegetative forms, are easily killed by heat. The temporary preservation of food by heating is a common custom. It is constantly made use of by the housewife in order to save some food that she knows will be spoiled in a short time if it is not so treated.

When this process is applied to milk in the household or on a commercial seale it is known as pasteurization. It received its name from the originator of the method, Pasteur, the great French bacteriologist, who first used it for the preservation of the wines of his native district in France. It was later used by brewers in order to prevent the formation of sediment in beers. Today much of the bottled beer is pasteurized. The process was later adopted by the dairy industry, and here has been widely used. The process is carried 
out for two reasons: (1) to prolong the time during which the milk will be fit for use in the household, (2) to destroy any pathogenic bacteria the milk may happein to contain.

In Germany milk is usually heated in the home. Hot milk is a regular item on the bill of fare of all German restaurants. The milk used for tea and coffee is also heated. This same custom also prevails in many of the southern countries as Mexico and Cuba. The people of these countries are accustomed to the peculiar taste of heated milk, which is objectionable to the American, accustomed to raw milk. In commercial pasteurization it is necessary to produce an article that the consumer will like. Therefore the demand here is for a milk that shows no abnormal flavor such as a cooked taste. Heated milk not only acquires this taste, but it loses its power of creaming to a great extent. Its property of curdling with rennet is also injured. If cream is pasteurized, it appears thinner than raw cream. All of these are objectionable changes from the standpoint of the consumer.

As commercial pasteurization is done largely to preserve the milk, the temperature must be sufficient to lill most of the bacteria present, and especially the disease-producing types. The most resistent of these is the tubercle bacillus and this of all the pathogenic bacteria is most often to be found in milk. It has been determined by careful trials that if the milk is heated to $140^{\circ} \mathrm{F}$. for twenty minutes, the tubercle bacilli will be destroyed, or if raised to $160^{\circ} \mathrm{F}$. and the exposure made for a moment they will also be killed. Both of these ways are used in commercial work. The first is done in the discontinuous pasteurizing machines in which the milk is heated for any length of time to any 
desired temperature. Where large quantities of milk are to be treated, the "continuous flow" machines are used, through which the milk passes in a constant stream.

Household pasteurization of milk. It is often desirable to pasteurize the milk to be used in the home, especially that intended for children, and when the milk comes from cows not known to be free from tuber-

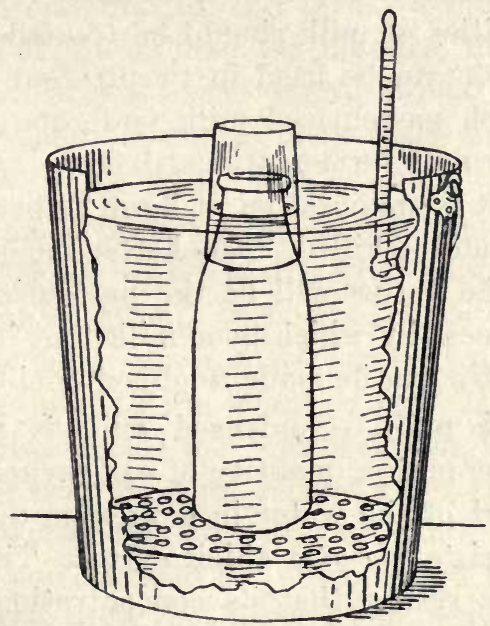

Fig. 10.-A Home-Made Pasteurizer.

The tumbler prevents the formation of a membrane on the milk during the heating and also protects the mouth of the bottle from dust.

culosis. The process can be easily carried out in milk bottles or fruit jars. These should be closed in some way in order to prevent the formation of the "skin" that forms on milk heated in an open vessel. This membrane has a protective influence on the bacteria embedded in it. The bottles are placed in a vessel having a false bottom to avoid breaking them. The vessel is filled with water to the height of the milk in the 
buttles. The water is heated to $150^{\circ} \mathrm{F}$. and kept at this temperature for twenty minutes. The bottles of milk are then removed and cooled at once.

In the pasteurizing process the bacteria that do not form spores are killed, but the spores are not destroyed. If the heated milk is not cooled rapidly and kept cold, these spores will germinate and by their rapid growth the milk will soon be rendered unfit for use. Only small quantities of milk should be treated at one time, no more than can be used in twenty-four hours. The change which pasteurized milk undergoes will be discussed under milk fermentations, p. 58.

In efficient pasteurization at least 99 per cent of the bacteria should be killed. The better the quality of the raw milk, the better will be the pasteurized milk. It is not a process by which poor milk that has abnormal odors or tastes can be made unobjectionable.

Condensed milk. Condensed milk is prepared by adding to the milk a quantity of cane sugar and evaporating a part of the water in a vacuum until the milk has the consistency of a thick syrup. This milk will keep for the reason that its concentration is so great that the bacteria that it contains are unable to grow. If it is diluted with water, they begin to grow and the milk soon spoils. Unsweetened condensed milk is also made. This has the consistency of thick cream and keeps because the cans of milk have been sterilized in steam sterilizers in exactly the same manner as canned corn and peas are treated.

Milk is also preserved by drying it until a powder is obtained. The drying is done in a number of ways all of which have been patented by the inventors. The milk powder is used largely by bakers. 


\section{CHAPTER V. \\ FERMENTATIONS OF MILK.}

A large number of kinds of bacteria enter the milk during its production on the farm. From the udder, the exterior of the animal, the manure, the barn-dust, utensils, and milker come many kinds of bacteria, ycasts, and molds. Many of these micro-organisms can grow in milk.

Composition of milk. Milk is composed of about 87 per cent water, in which is dissolved about 5 per cent of milk sugar (lactose), various salts, as common salt, caicium phosphate, ete, and 0.5 per cent of albumen, a substance resembling the white of egg. In suspension in the milk there is $2-4$ per cent of casein, the substance that gives to skim milk its whitish color and makes up the larger part of the curd in sour milk.

Milk is a perfect food for animals and also for most bacteria. The different kinds when growing in milk use the various substances it contains as food. From these they produce many products which alter the milk as to appearance, odor, and taste. The various changes pioduced are known as the fermentations of milk, and are designated by the name of the most important byproduct formed. Thus, the souring of milk is called the lactic acid fermentation, because lactic acid is the most prominent substance in this change.

Souring of milk. The souring or acid fermentation. of milk is so common a change that it is looked upon as 
a perfectly normal occurrence. Indeed any milk that does not sour when kept at ordinary temperatures for some tiine is regarded with suspicion and is thought to have been treated with preservatives. The souring of milk is not an inherent property, but is due to certain kinds of bacteria that gain entrance to it after its withdrawal from the cow. These bacteria are found universally distributed and unless precautions are taken to exclude them, they are certain to enter the milk.

The bacteria causing the souring of milk use a part of the milk sugar as food, forming from it lactic acid. This substance is not a solid like the sugar but a syruplike liquid, having no color or odor and a sour taste. The bacteria producing the change are known as the lactic acid bacteria. The acid they form gives the fermented milk its sour taste and causes it to curdle. Milk that contains about 0.3 per cent of acid tastes scur and curdles when heated. As the bacteria contiinue to develop the acidity increases. At 0.6 per cent the milk curdles at ordinary temperatures. When the aridity reaches about 1 per cent, bacterial growth ceuses and no more acid is formed. The bacteria like all other forms of life are injured by their own by-products unless these are removed. In milk the acid is formed in such quantities as to cause ultimately the death of the cells. The bacteria in the milk can not get away from the acid they have produced, hence growth ceases, although plenty of food remains. If all of the sugar of the milk were changed to acid, the acidity would be 4 per cent. instead of 1 per cent.

Kinds of lactic acid bacteria. The lactic acid bacteria come from various sources. One type is often found in the dust coming from the skin of the animal 
and in the dust of the barn. They are also found on the milk utensils. Another type is found in great numbers in the manure. The first is a desirable form and is necessary in the making of butter and cheese, the latter is very undesirable in every way.

The number of lactic acid bacteria in freshly drawn milk is always very small, often aggregating not more than one in one thousand of the total number of bacteria present. In sour milk, 99 per cent. of the bacteria are lactic organisms. This great change in the flora is due to the fact that the lactic bacteria find more favorable conditions for growth in milk at ordinary temperatures than any other kind that enters the milk. They grow rapidly and the acid they produce is antagonistic to many other species. Meat, eggs, and animal foods in general putrefy. Milk does not under ordinary conditions, because the acid formed by the lactic bacteria prevents the growth of the putrefactive forms, just as vinegar keeps pickles from rotting. Meat can be preserved by placing it in milk in a stoppered bottle. If it were not for the lactic bacteria, milk instead of having a pleasant taste and an agreeable smell, would putrefy and give off as offensive odors as do meat and eggs. This is shown when a little milk is spilled onto the stable floor $n \mathrm{r}$ into the water of a cooling vat. The lactic bacteria are to be looked upon as the friends of man. They are perfectly harmless and even beneficial to him. Buttermilk, a form of sour milk, is enjoyed by most people as a refreshing drink. It contains millions of lactic acid bacteria in every drop. Clabber, curds, and cottagecheese are other forms of sour milk and are widely used as human food.

The curd which the desirable type of acid-forming bac- 
teria produce in milk is perfectly homogeneous, showing no holes due to gas or no whey expressed from the curd. The odor is agreeable, the taste sour, but not bitter or offensive in any way.

The lactic bacteria do not form spores and hence are easily killed, if milk is heated. If milk is pasteurized and subsequently kept free from lactic bacteria, it will not sour, but will putrefy due to the development of the spores not killed by the heating. Often the first sign of spoiling in pasteurized milk is the appearance of a bitter or other undesirable taste. Frequently it does not curdle for a long time. One of the dangers in the use of pasteurized milk is the fact that the consumer has no way of telling how old it is. It may appear normal in every way and yet be harmful to the health.

The lactic bacteria grow best at temperatures from $70^{\circ}-95^{\circ} \mathrm{F}$. If the milk is cooled below $50^{\circ}$, growth goes on very slowly, at still lower temperatures, $32^{\circ}-35^{\circ}$, the growth of lactic bacteria is wholly prevented, but other types develop which may cause the milk to become harmful.

It is a widespread belief that thunder storms cause the milk to sour. Electricity has no effect on milk, the apparent effect is due to the high temperatures that always accompany such storms, causing the bacteria to grow more rapidly.

Undesirable lactic bacteria. The desirable types of iactic bacteria produce other by-products than the lactic acid and to these is due the odor of sour milk. The undesirable lactic germs form some lactic acid but larger amounts of other acids such as acetic acid. They also form gaseous by-products that give to the milk an objectionable odor and taste, injuring it especially for but- 
ter and cheese making. These forms come from dirt and manure. They are present in milk in greater or less numbers, depending upon the degree of cleanliness used in producing and handling milk. If they are numerous in a sample of milk, the curd will be filled with gas-holes, instead of having the homogeneous appearance of the curd from good milk. The curd may even be so filled with gas as to float on the surface of the whey. If these forms are few in number and the desirable ones predominate, the gas holes will be less abundant. These bacteria form no spores, and hence are not found in pasteurized milk. They grow at somewhat higher temperatures $\left(95^{\circ}-105^{\circ} \mathrm{F}\right.$. $)$ than the desirable lactic bacteria.

Abnormal fermentations of milk. The aci fermentation of milk by reason of its common occurrence is looked upon as a normal change. Various other types of fermentations that are quite different from the acid fermentation and hence are called abnormal fermentations or milk faults, appear now and then in milk.

Sweet curdling of milk. Milk may curdle and yet the taste be perfectly sweet. It is evident that the curdling in this case must be due to some other factor than the lactic acid. As is well known sweet milk may be curdled by the use of rennet which is prepared from the fourth stomach of the young calf. The rennet used in cheese making comes from this source. Rennet will curdle several times its weight of milk in a short time. Substances such as rennet are called enzymes. All the digestion in the alimentary tracts of man and animals is carried on by enzymes in the saliva, the gastric juice, the pancreatic juice, and the intestinal fluids.

Many bacteria form enzymes of various kinds. The 
putrefactive ones produce an enzyme similar to rennet. When these forms are numerous, i. e., more abundant than the sour milk bacteria, the milk may curdle, although remaining quite sweet. If the milk is kept for scrme time after curdling, it will be noted that the curd becomes soft and reduced in amount due to its digestion by other enzymes that resemble trypsin found in the pancreatic juice of animals.

Many of the putrefactive bacteria form spores. These spores are not destroyed in the pasteurization of milk. Due to the development of these spores, the pasteurized milk often curdles although it still tastes sweet. The curd is soft and large amounts of whey separate from it. Such milk is not wholesome, even before it shows any signs of curdling, and it may be dangerous to human beings, especially to children. The organisms producing these changes get into milk from manure and dirt. They are especially numerous in dust from hay, straw, and corn fodder. Such feeds should not be fed until after milking. These bacteria do not find such favorable conditions for growth in milk as do the lactic organisms. The latter by the acid they produce render the milk still less favorable for the putrefactive germs.

Slimy fermentation of milk. One of the most frequent abnormal fermentations is the slimy or ropy change. Such a condition may appear when the milk is drawn from the cow, in which case it is usually due to inflammation of one or more quarters of the udder. When the trouble is due to bacteria, the milk becomes slimy a day or so after it is withdrawn from the animal. The causal organisms produce a slimy substance in milk, sometimes in such abundance that the milk can be drawn out into long threads. 
The greatest amount of trouble with slimy milk occurs during the warmest weather and in bottled milk that has been kept in a refrigerator. The cream is often slimy, while the lower layers are apparently normal. In other

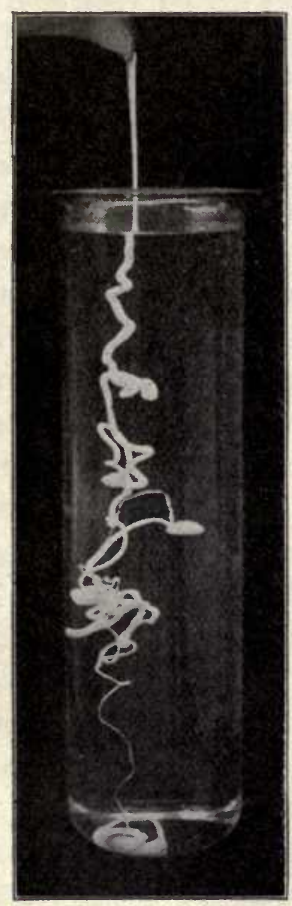

cases the entire mass of milk becomes thick and viscous. The bacteria producing the first type are aerobic and grow best at low temperatures. Outbreaks of this trouble do not usually persist for any length of time, if care is taken to sterilize thoroughly the milk utensils. The bacteria causing the trouble do not form acid.

The second type in which the entire mass of milk becomes slimy is usually due to bacteria that form acid. The milk is curdled, but the curd instead of being easily broken up as in the normal acid fermentation is very ropy. This type of fermentation is rare. In Norway slimy milk is prepared for human food. It has an agreeable acid taste much like the taste of butter-milk. It is very ropy and appears unappetizFig. 11.-SLimy Mruk. ing to one not accustomed to it. In Holland ropy whey, which is produced by much the same kind of bacteria as the Norwegian ropy milk, is used in the making of Edam cheese in order to overcome trouble in handling poor milk, just as the American cheese maker uses lactic acid bacteria 
contained in sour milk as a starter to prevent gassy cheese.

None of the rapy fermentations are harmful as far as health is concerned, but they are often the cause of considerable loss to the milk dealer. They do not appear to injure the use of milk for butter. The source of the bacteria in some of the outbreaks studied has been found to be the water to which the cows had access.

Alcoholic fermentation of milk. As is well known in order to produce any of the fermented drinks, such as beer or whiskey, the wort or mash (the infusion of barley or other grain used) is seeded with yeasts, which act on the sugar formed from the starch of the grain, producing alcohol and carbon dioxide. None of the bacteria produce alcohol in appreciable amounts, this property being confined in the main to the yeasts. The ordinary type of yeasts can not ferment milk sugar, but in milk, butter, and cheese, yeasts are found that possess this property. When these are numerous in the milk they may injure the butter and cheese, giving these products a yeasty flavor and odor. Through the gas produced from the sugar, holes may be formed in the cheese and not infrequently gas is formed in such abundance as to cause the cheese to crack open.

Yeasts grow best in an acid medium. This is shown by the ease with which all fruit juices, as apple and grape juice, undergo alcoholic fermentation, even when no yeast is intentionally added. Wild yeasts occur in sufficient numbers on the surface of the fruit to seed the juice. In less acid substances the bacteria appear first. In whey vats that are not carefully cleaned, a favorable place exists for yeast growth. The whey becomes acid due to the growth of the acid-forming bacteria, and as it still 
contains sugar, consequently, conditions are favorable for yeast development. Milk cans in which sour whey is carried, unless carefully washed, may serve to contaminate the milk to such an extent as to produce truuble in cheese factories.

The use of alcoholic drinks seems to have been inore or less common with nearly every type of people. The Fgyptians made beer from the grain they raised. The nomadic tribes, having no grain, discovered methods of. making alcoholic drinks from the milk furnished by their herds of cattle, goats, and horses. In Russia such a fermented drink, called koumiss, is made from mare's milk. In other countries similar drinks, but prepared principally from cow's milk, are called kefir, matzoon, and leben. They all have an acid taste due to the acid formed by the lactic bacteria, and they contain nearly half as much alcohol as a light beer. Such fermented milks seem to be more easily digested than raw milk, due un. doubtedly to the fact that the casein is precipitated in a finely divided condition and to the acid present.

Bitter milk. Bitterness in milk may be due to bac. teria or to certain feeds. Ragweed is often claimed to be the cause of such milk. If the feed is at fault, the milk will show the bitterness when it is drawn from the cow, and instead of increasing in intensity, as is likely to be the case if the cause is bacterial, the taste usually becomes less and less evident as the age of the milk increases.

Various kinds of bacteria may cause the milk to taste bitter. Some of the acid organisms cause such a change, but more frequently the digesting bacteria are the source of the trouble, and since these are more apt to develop in pasteurized milk than in raw, a bitter fermentation is 
more frequently noted in pasteurized milk and cream than elsewhere. Low temperatures also favor the growth of certain of the types causing the trouble.

Colored milk. Red milk is of frequent occurrence and is most often due to the presence of blood which has gained entrance to the milk ducts through a wound in the udder. The presence of the blood can be recognized with ease as the red blood corpuscles, that give the blood its color, are heavier than the milk serum and therefore settle to the bottom of the milk receptacle. When the color is due to the presence of blood, the milk will be colored when it is drawn.

There are other changes that may occur in which a reddish coloration may develop, due to the growth of bacteria. Such troubles are rare and have but little economic importance. Other pigment-forming bacteria occasionally develop in milk causing abnormalities as to color.

Treatment of abnormal fermentations in milk. If the milk from a dairy is constantly contaminated with bacteria causing undesirable changes to such an extent as to injure the milk for butter and cheese, some remedial measures must be taken. In most cases a thorough cleaning of the milk utensils on the farm, the cleaning of the milk-room and the barn, together with the exclusion of the cows from mud-holes, ponds and creeks will suffice. When these measures do not succeed, recourse must be had to the employment of disinfectants, the use of which will be described elsewhere.

The discovery of the source from which the harmful organisms come is an important thing, for little can be done toward overcoming the defects until that is known. 
The butter or cheese maker, receiving milk from a number of farms, often finds it necessary to trace to its source on the farm the abnormal fermentation causing him trouble and loss. The test most often used for this purpose is designed especially to detect the most frequent of the troublesome fermentations of milk, and is known as the Wisconsin curd test. The sample to be tested must be carefully collected in fruit jars which have been sterilized by boiling, in water. The various samples must not be taken by the use of a dipper unless it is sterilized before each sample is taken. If this is not done, the bacteria remaining on the dipper may be sufficient to change the result in any sample from what it would have been, in case the sample had been taken in such a way as to avoid such contamination. The best way to take the sample is to fill the jar by pouring directly from the can of milk to be tested.

The milk is warmed to $98^{\circ} \mathrm{F}$., ten drops of rennet added, and as soon as a firm curd is formed, it is cut into small pieces by means of a sterile table knife. The cutting of the curd allows the whey to be expressed. As it collects it is turned off until the small pat of curd is quite dry. The jars are kept at $98^{\circ}-105^{\circ} \mathrm{F}$. for ten to twelve hours. When the curd forms most of the bacteria in the milk are caught in the curd, the shrinking of the same concentrating the bacteria into about one-tenth of the volume of the milk. They are held in place as in the plate cultures described in Chapter II. They multiply rapidly, forming colonies in the curd. The jars are kept at high temperatures in order to favor the growth of the undesirable bacteria. After ten to twelve hours the curds are examined as to their texture, flavor, and odor. A curd which presents an agreeable acid odor, a close texture, 
few or no gas holes, and no slimy condition is certain to have come from a good milk. If many gas-forming bacteria are present, the curd will be filled with small holes, and will have a less agreeable odor than a curd from good milk. The greater the number of gas-forming bacteria present, the more spongy is the curd mass. Sometimes ill-smelling curds are noted that are not accompanied by a spongy texture.

Various other abnormal fermentations may be discovered by the use of the curd test. It may be necessary to make similar tests on the milk of each cow before the source of the trouble can be found. 


\section{CHAPTER VI.}

\section{RELATION OF BACTERIA TO BUTTER.}

If fresh sweet milk is separated and the cream churned at once, a butter will be obtained which has but little flavor or taste. This "sweet-cream" butter is used exclusively in France, Southern Germany, and Italy. The flavor comes from the milk itself, and is known as the primary flaqvor of butter. If, however, the same cream is allowed to ferment, due to the growth of the bacteria which it contains, the butter will have a much higher degree of flavor. Ripened or "sour-cream" butter, is the type of butter usually made in northern European countries, England, and America.

The manufacture of sour-cream butter undoubtedly arose because of its greater convenience. In making sweet-cream butter, the milk has to be kept cool during the time required for creaming and the cream churned daily. Under modern conditions, by the use of the centrifugal separator, sweet-cream butter can be easily made, but heretofore, sour-cream butter was easier to make because the cream could be accumulated in quantities and churned when convenient.

Flavor of sour-cream butter. In the acid fermentation of milk and cream, not only lactic acid but other acids are produced, as well as many other products, of which little or nothing is known. The butter fat has properties similar to other fats, one of which is to absorb 
and hold many substances having pronounced odors and tastes. In the souring of cream, various products are formed, some of which are absorbed by the butter fat, and give to the sour-cream butter its peouliar flavor. The lactic acid itself is of no importance as far as flavor production is concerned.

That the by-products of the lactic fermentation are the important thing, and not any change in the fat during the souring process can be shown by the fact that if sweet cream is mixed with sour skim milk and churned at once, the butter will have as much flavor as though the cream itself had been allowed to sour. This fact is made use of by renovated butter manufacturers and oleomargarine makers to give taste and odor to the tasteless fats they employ.

Spontaneous ripening of cream. All lactic acid bacteria do not produce proper flavoring substances. Those which break up the milk sugar with the formation of gas in the milk frequently impart an undesirable flavor to butter. Because of the fact that clean pure milk usually undergoes a desirable type of fermentation, the so called spontaneous or natural ripening of cream generally results in the production of a satisfactory product. This is the method usually employed on farms and where care is taken, the best quality of butter can often be produced. The farm product is not likely to be as constant in quality as the factory butter.

Home-made starters. With the advent of the modern creamery, it became possible to make a more uniform product because conditions could be more closely controlled. The most prominent factor in this is the churning at regular intervals. This should be done when a 
proper amount of acid has been developed in the cream. As the development of acid turns generally on temperature conditions favorable to the growth of bacteria in the cream uniformity in the ripening temperature first came to be practiced. Experience also showed that the addition of already fermented milk could be advantageously employed, so gradually sour milk or butter milk began to be employed. These home-made starters have now long been used with success.

A recognition of the relation of bacteria to the process of cream ripening is comparatively recent and has resulted in much improvement in the preparation of the starters used in the cream. The modern operator uses essentially the following procedure in the preparation of. a home-made starter: a small amount of milk which the butter maker thinks has been handled under clean conditions is allowed to sour. If the soured milk has a desirable flavor and odor, it is added to a larger quantity of milk which has first been heated to a temperature sufficiently high to kill the acid-forming bacteria and which has been cooled to $70^{\circ}-90^{\circ} \mathrm{F}$. This mass of milk sours quickly under the influence of bacterial growth. When it reaches the proper degree of acidity, this natural starter is added to the cream, a small amount being reserved with which to inoculate a fresh quantity of heated and cooled milk. By this process the starter is propagated from day to day and the butter maker is able to control in large measure the type of fermentations in the cream. Sooner or later the starter propagated in this manner becomes undesirable in flavor and must be rejected. A new starter must then be developed and propagated as described.

The home-made starter has been of great service in the 
development of dairying and is still employed by many butter makers. It has, however, been gradually supplanted by the pure-culture or commercial starter. This more recent advancement is due to the discovery of the Danish bacteriologist, Storch, who was the first to show the relation which bacteria hold to the ripening of cream. Instead of relying on natural fermentations to produce the starter, he separated, from ripened cream, the specific organisms found therein and tested them as to their flavor-producing properties. Those which were found to produce the most desirable flavors were then cultivated in quantities so that they could be distributed to the creameries.

The pure culture is thus supposed to be a more highly selected type of the organism than would be found if reliance was placed on natural fermentations alone. The pure cultures are extensively used at the present time and aid in maintaining uniform conditions in the ripening of the cream since the butter maker can use the same organism continuously. When the starter propagated in the creamery becomes undesirable for use in the cream, a new pure-culture starter is obtained from the manufacturer.

Pasteurization of cream for butter making. The cream to which the pure-culture starter is added contains, of course, as does all the milk and cream, lactic acid and other organisms of various kinds. These naturally develop in the cream to a greater or less extent when the pure-culture starter is added to raw cream. The flavor of the butter is thus the result of the combined effect of both the acid bacteria already present and those added. It was as though grain had been sown on an unplowed and weedy field. 
The next step in the history of butter making, a step toward better control of the flavor of the product, was to heat the cream to kill the acid bacteria already present and thus, to give a free field to the bacteria in the starter. The pasteurization of cream is a most successful process. All the butter made in Denmark is from pasteurized cream; much of the butter made by large creameries in this country is also treated in the same way. It represents the highest type of modern butter making. The cream is pasteurized in "continuous flow" machines in which it is heated momentarily to $170^{\circ}-190^{\circ} \mathrm{F}$., and cooled at once. Before churning the cream must bs cooled to $50^{\circ} \mathrm{F}$. and kept at this temperature for some hours, otherwise the butter is apt to have a soft and mushy texture.

Ripened cream churns more easily than does sweet cream and the loss of butter fat in the butter-milk is not so great. This is of considerable importance in creameries where the daily output is several thousands of pounds.

Details of cream ripening. The cream should be from clean milk and allowed to sour at about $70^{\circ}-80^{\circ} \mathrm{F}$. Pure-culture starters have not been extensively used on the farm, but undoubtedly they would be of great value. They can be propagated in small vessels as fruit jars, milk bottles, etc. The details that must be observed in the propagation need not be given here as full instructions accompany each pure culture sent out by the manufacturers.

The cream should be allowed to sour until the acidity is from 0.5-.65 per cent. If the acidity is lower, the flavor of the butter will be very mild. If the acidity increases to 1 per cent, the flavor is apt to be undesirable. 
The poor quality of dairy butter is generally due to the fact that no control is maintained over the ripening of the cream, too much acid usually being developed in the cream.

Deterioration of butter. Butter is in its best condition as soon as it is churned and prepared for the market. Its best flavor is retained for several days; the period being lengthened by storage at lower temperatures. At summer temperatures, the flavor becomes impaired in the course of a week or so. The nature of these changes is very obscure and they are designated usually as "off" flavors.

It has been noted that sweet-cream butter has very poor keeping quality at ordinary temperatures when compared with the sour-cream product. This undoubtedly is due to the fact that many kinds of bacteria are present in sweet-cream butter. In sour-cream butter the majority of the bacteria are acid-forming, most of which have no injurious effect on the butter. The greater care used in making the butter, the better its keeping quality. If it is made from very clean milk, and the cream soured by pure cultures, the keeping quality will be excellent. It may be further enhanced by pasteurization of the cream.

- The causes of the deterioration of the butter are not well known. It is certain from what has been said that the bacteria must play an important role, for in no other way can the influence of souring the cream and of pasteurization be explained. The same is also indicated by the influence which the water used to wash the butter has on its keeping quality. If the water is pure, as from a deep well, its influence will be small, but if surface water from shallow wells is used, which contains many 
bacteria coming from the soil, the keeping quality will be greatly injured. This has led to the heating of the wash water in creameries when the supply is not above question.

The changes which butter undergoes are usually expressed by the word "rancid." At least two different changes can be distinguished. The butter may develop. a flavor or odor resembling that of tallow. This is due, at least in part, to the action of light and air on the fat. Butter in tubs keeps better than in small packages. The true rancidity, a change in which the butter acquires the odor and taste of spoiled cocoanut milk is due largely to bacteria.

The number of bacteria in fresh butter is very large but diminishes rapidly after churning on account of the lack of food and the injurious action of the salt, which is usually present in such quantities as to form a saturated brine with the water in the butter. The lactic acid bacteria decrease with especial rapidity while undoubtedly some other forms of bacteria and molds are able to grow in spite of the salt.

The role of the bacteria in the spoiling of butter is further emphasized by the effect of cold storage on the butter. In order to preserve it, modern butter storage rooms are kept below zero Fahrenheit. After months of storage, the butter is unchanged. It does, however, spoil very quickly on being removed from the cold room; much more quickly than before storage. Preservatives are widely used in butter, not in our own country, but in Australia and New Zealand in the butter to be shipped to England.

Undesirable flavors in butter. As has been previously mentioned, the kind of feed may influence the 
taste and odor of the milk. The milk may not have a marked taste, while the butter prepared from it may show the influence of the feed to a great degree, because the fat absorbs the flavoring substances and thus they are concentrated in the butter. It is practically impossible to feed turnips, cabbage, and rape without the taste of these vegetables appearing in the butter. Green clover, strong silage, and various weeds which the cattle may eat when the grass is short in the pastures may also injure the butter. Butter brought in contact with pronounced odors, such as that of bananas, will absorb enough so that the flavor is very evident. This absorption by the fat may take place either before or after churning. For this reason milk, cream, and butter should be kept in a place free from all odors. Weigmann of Germany has found certain kinds of bacteria in milk which impart to the butter a flavor like that of turnips.

"Fishy" butter is quite common causing in some creameries a large loss. The true cause of this trouble is not known with certainty.

Moldy butter. The common molds, which appear so quickly on bread, cheese, etc., do not as a rule cause trouble in butter but certain other kinds of molds are especially troublesome. They develop mainly in the outer layer of the butter, where they have access to the oxygen of the air, or on the parchment paper or inner face of the butter tub itself. 


\section{CHAPTER VII.}

\section{RELATION OF BACTERIA TO CHEESE.}

Cheese is an important item in the dietary of European people. It has a high food value because it represents a concentration of three-fourths of the solids of the milk to about one-tenth of their original volume. It is also largely used as a condiment. In many European countries the food supply of a large part of the people is coarse and relatively tasteless. A small amount of highly flavored cheese renders such food more appetizing.

Manufacture of cheese. Cheese is made from the fats of the milk, the casein, certain ash constituents, and a part of the milk serum. The casein is curdled by allowing the milk to sour or by the addition of rennet. The curd holds the fat globules of the milk, and when it shrinks under the influence of heat and acid, whey is expressed, leaving a mixture rich in fat and casein, and containing from 30 to 50 per cent of milk serum or whey, depending on the kind of cheese.

Types of cheese. Cheese may be grouped into two classes: (1) Those in which the curd is obtained by allowing the milk to sour; (2) those in which the curd is obtained by the use of rennet.

The only important kind of the first class in this country is the cottage or Dutch cheese. Bacteria function in the manufacture of this variety as the curdling of the casein is due to the souring of the milk. Heating the 
milk also facilitates the coagulation of the curd. The whey is removed from the curd by straining. The cheese is then salted and is ready for use. Its flavor is that of sour milk, or butter milk, as it is really a concentrated form of sour milk. It contains, of course, an immense number of lactic acid bacteria. Cottage cheese has poor keeping qualities, since mold soon begins to grow on the surface of the moist mass of curd.

As representative of the second group, the typical American cheddar and the Swiss cheese are the best known. In these types the casein is curdled by the addition of rennet extract, the curdling action being dependent upon the coagulating enzymes contained in this animal extract. By cutting the curd mass and warming the same, the whey is rapidly expressed, leaving a firm solid curd, which is formed into various shapes by placing the same in moulds. The fresh curd is tough, rubbery, tasteless, and practically insoluble in water, but when placed under proper curing conditions, becomes in time, soft, plastic, high in flavor, and a large part of it is soluble in water. A "ripe" or cured cheese is easily di-, gested while green cheese is indigestible.

There are at least four hundred different kinds of cheese, but those which are of importance in the markets of the world do not exceed twelve to fifteen. The remainder have merely a local market in the districts where made. All varieties are produced from milk and yet the resulting product is far different. This indicates that the conditions of manufacture and curing of the product, directly or indirectly, play an important part in determining the type of cheese.

Milk for cheese making. It is very important that the milk for cheese shall be normal in all respects and 
that it shall not contain injurious kinds of bacteria. As will be noted later, the lactic acid bacteria are of much importance in the cheese-making process. The cheese maker ean add these organisms in the form of a starter, just as is done in butter making. The farmer should furnish to the cheese maker clean milk which has been kept cold so as to prevent the growth of bacteria as far as possible. If this is done the cheese maker will have little trouble, and the product will be good. 'In butter making, fairly good butter can be made from sour cream, or even cream that has an undesirable flavor if it is pasteurized and ripened with a proper starter. The cheese maker can eall no such aids to his service. He can control in part the course of the changes that occur during the making process, but after the cheese is made, he is wellnigh helpless so far as the quality of the cheese is influenced by the milk.

The main duty of the producer lies in the giving of especial attention to the washing of the milk cans as these utensils are generally employed for the return of the whey to the farm. All of those factors referred to under the production of clean and wholesome milk are here equally applicable.

Ripening of cheese. The rennet which is used to curdle the milk is obtained by extracting the fourth stomach of calves that have received no other food than milk. It can be obtained from many other sources but not so advantageously. It is prepared by the manufacturers in liquid or dry form. Formerly each cheese maker prepared his own rennet extract from the dried rennets. The Swiss maker still follows this practice. The rennet extract contains the enzyme, pepsin, which is found in the gastric juice of all kinds of animals. This enzyme. 
acts only in an acid medium. The reaction of the contents of the normal stomach is acid. Certain kinds of stomach trouble. and indigestion are due to a lack of acid in the stomach, the food remains unacted upon by the stomach juices, while putrefactive changes occur which are marked by belching of gas and offensive breath.

The immense number of lactic acid bacteria that are present in the milk are concentrated in the curd just as are the fat globules of the milk. In the warm moist eurd they grow rapidly and change the sugar of the whey to lactic acid. This acid enables the pepsin of the rennet extract to act, changing the tough, rubbery, insoluble curd to a soft and partially soluble form. Without the lactic acid bacteria to produce this change the cheese does not ripen. They are absolutely essential to the ripening of cheese. Owing to the favorable growth conditions, during the making and in the first stages of the ripening of the cheese, an immense number of lactic acid bacteria are found therein. This number rapidly decreases within a few days as the sugar is soon completely fermented, and conditions are no longer favorable for growth.

Green cheese has none of the flavor which a ripe cheese must have in order to make it valuable as a commercial product. With increasing age the flavor becomes more and more marked, until it may become so strong as to be undesirable. The cause of the typical flavor of cheddar or American cheese, as it is often called, is unknown. It has been found that the cheese must be made in a certain way and ripened under certain conditions, and unless this is done the product will not have the flavor of cheddar cheese. For example it does not seem possible to make a cheese from pasteurized milk, or to omit the salting of the curd. Such things strongly indicate the work of bacteria in the formation of the flavoring substances. 
When the milk is clean and a pure-culture starter is used the cheese is generally of good quality. If the milk is dirty, because of careless methods on the farm, a large number of gas-forming bacteria will be present. These grow in the curd together with the lactic acid bacteria, causing the curd to be filled with holes due to the imprisoned gas, and greatly injuring the flavor of the cheese. The greatest trouble with which the cheese maker has to contend is gassy milk. Milk of this nature can be detected by the use of the Wisconsin curd test (p. 63).

Other kinds of bacteria than the gas-forming types may also injure the cheese. If the acid-forming bacteria do not grow quickly in the milk, putrefactive organisms may develop and cause offensive odors. In case of some of the foreign types, the cheese may change from a firm to a soft, slimy mass which has a most offensive odor and bitter taste. The putrefactive bacteria can not develop in a normal cheese because of its acid reaction. Chromogenic bacteria may grow in the milk and cheese and produce colored spots in the cheese. A trouble met with in Canada and New York is called the "rusty spot." It does not injure the taste of the product, but causes it to have a strange and unappetizing appearance and of course lowers its commercial value.

Foreign types of cheese. There are on the American markets many types of cheese that have been imported from the countries to which they are peculiar. Among the most important of these are the Swiss cheese or Emmenthaler, made in Switzerland, Roquefort from France, Gorgonzola from Italy, Stilton from England, Limburger from Germany, and Camembert and Brie from France. Because of the high price that these cheese 
bring, efforts have been made to manufacture them in America. The greatest degree of success is met in the making of Swiss and Limburger. Many millions ofpounds of these cheese are made annually in Wisconsin. Camembert is made to a small extent in some of the eastern states. The manufacture of the remaining kinds has not yet been put on a commercial basis in this country.

Swiss cheese. This cheese is made from very sweet milk. It is especially important that the milk be produced under such conditions as to prevent contamination with gas-forming bacteria, since the Swiss maker can not make use of the means available to the cheddar maker to prevent and overeome these forms. The Swiss makers fear gassy milk very much; they insist that the farmers shall not include in the milk brought to the factory that drawn from a cow suffering from garget since they think that such milk will cause gas in the cheese. The Swiss maker insists that the farmer shall not strain his milk. The milk is strained at the factory. By watching the appearance of the strainer the maker can detect dirt in the milk and often cases of udder trouble in the herds of the patrons. He thus knows better the conditions under which the milk was produced than does the cheddar maker whose patrons'strain the milk on the farm.

Rennet and the lactic acid bacteria play the same part in the ripening of Swiss cheese that they do in cheddar, but as the flavor is different the causes operative here must be other than in cheddar cheese. Swiss cheese does not have the solid texture of cheddar cheese but is studded with holes from the size of a hazelnut to a hickorynut. These holes are called "eyes" and a cheese that lacks them is termed a "blind" cheese. As these openings exist in a normal cheese they may be called the trade 
mark of this type of cheese. They are of commercial value since a cheese that lacks them will not sell for as much as one of similar flavor and texture containing the eyes. At the time when the cheese is supposed to be at its best, the eyes often contain a clear brine which is termed "tears." The eyes are caused by bacteria that change a portion of the lactic acid to propionic and acetic acids. Carbon dioxide is also produced. This gas produces the holes. The change of the lactic acid to other acids undoubtedly influences the flavor of the cheese.

Roquefort, Gorgonzola, and Stilton cheese. There are three kinds of cheese found in the world's markets that are very peculiar as to the manner of ripening. These cheese are Roquefort, Gorgonzola and Stilton. The first is made in France from sheep's milk, the others are made from cows' milk. These cheese are luxuries, selling for fifty to seventy-five cents a pound.

The rennet and lactic acid bacteria play the same role in the manufacture and ripening of these cheese as in the cheddar cheese. One of the causes of the peculiar flavor of these cheese is a mold very similar to the ordinary blue-green bread mold. In the making of Roquefort cheese, the curd when put to press is sprinkled with bread crumbs upon which the mold is growing. This mold like all others can grow only in the air, and in order to allow the air to penetrate into the cheese, it is pierced full of small holes by means of slender needles. The mold grows and forms its greenish spores, giving to the cheese, when cut, the appearance of green and white marble. The flavor is characteristic and is produced only when the mold is present.

Gorgonzola and Stilton cheese contain the same mold 
and present the same appearance. The mold is not added intentionally, the maker relying on a sufficient seeding of the curd from the utensils, etc.

Limburger and Camembert cheese. The cheddar and Swiss cheese are typical examples of the so called "hard" cheese. Limburger and Camembert are "soft" cheese. The soft varieties are always prepared in small molds, since it would be impossible to handle them if they were large, and also the proper ripening process proceeds from the outer layers toward the inside. A cheddar cheese can be made of any size desired; a large one ripens as well as a small one since the process goes on uniformly throughout the entire mass of the cheese. Swiss cheese ripen in the same manner but they are always made with a large surface compared to the volume of the cheese on account of the method of salting. The salt is applied to the surface of the cheese.

The soft cheese will keep but a short time while many of the hard types will keep for years. The most important of the soft cheese are Limburger, Camembert, and Brie. In all of these the rennet and lactic acid bacteria play the same part in the ripening process as they do in cheddar and Swiss cheese. Again, as in Roquefort, molds are one of the factors in ripening and in flavor production. In the case of Camembert and Brie the mold growth is confined to the outside of the cheese, instead of growing through the cheese. The mold instead of producing colored spores as in Roquefort is white. At least two molds are necessary for the development of the typical flavor, one the common mold of milk, Oidium lactis which forms a white velvet-like growth on the surface of sour milk, the other a white mold closely related to the mold found in Roquefort cheese. The cheese are not 
usually inoculated with the molds as the accidental infection in old factories is sufficient. Even under the best of conditions many cheese do not produce a typical flavor and must be sold at a low price.

As stated the ripening of these cheese gradually passes from the outside to the inside. When the influence of the mold has penetrated to the eenter of the cheese the ripening is completed. The cheese then begins to deteriorate. If the cheese is too large, the outer layer becomes overripe before the inner part is ripe.

Limburger cheese is similar to Camembert and Brie in that the ripening process begins on the outside of the cheese. The kinds of bacteria and molds that are essential are not well known. A reddish-brown layer of mold and bacterial growth develops on the surface. The action of this mass of growth gradually penetrates into the cheese, changing the color of the curd from a white to a translucent yellow. The typical flavor is connected with the growth of these organisms. 


\section{RELATION OF BACTERIA TO MARKET MILK.}

The demands of the cities for an increased milk supply are constantly more pressing. Each year the zone from which they draw their supply is widened, until in some cases it extends for hundreds of miles. The milk trains for New York start from the St. Lawrence valley over two hundred miles away. In the winter the milk zone of New York city is extended much farther, milk and eream being shipped from Ohio. In Europe, progressive Denmark has exported milk, supplying in considerable quantities milk to the Berlin market.

Not only. is there a steady increase in the amount of milk needed, but as public opinion becomes more intelligent there is a growing demand for an improvement in quality as well. It is becoming more thoroughly recognized that many of the infantile diseases are dependent upon the quality of the milk supply. Consequently, city boards of health are increasing the rigidity of their inspection service. What the cities want is pure milk drawn under clean conditions from healthy cows, and handled in a sanitary manner.

In the city of two decades ago, and in the small city and town of today, the milk is largely peddled on the streets by the farmer.

There is then a direct contact between the producer and consumer. The latter can easily find how the milk 
he consumes is handled if he desires to do so. The appearance of the wagon and the delivery man is certain to mirror quite accurately the condition on the farm with reference to cleanliness. With milk purchased from a dealer, with the farm many miles away, the consumer cannot, even if he wishes to do so, determine the conditions at the point of production. The city has had to step in and see that its people are receiving clean and healthful milk.

City regulations. Each city has met the problem in its own way. The city health department establishes rules to which every farmer must conform if he wishes to sell milk in the city. In order to determine whether the producer does meet the conditions imposed, the farms are inspected by a representative of the health department. Certain standards are established and the farm inspection is supplemented by tests made in the laboratory. The eity often demands that the milk shall not contain more than a certain number of bacteria (for example 500,000 or $1,000,000$ per cubic centimeter) and milk containing a greater number is looked upon as unlawful milk. The milk of the farmer who does not conform to the rules is returned to him or is confiscated by the city.

Certified milk. Some cities allow various grades of milk to be sold and prescribe the methods that shall be used in the production of them. One grade of milk to which a great deal of attention has been attracted in the last few years is that known as certified milk. Physicians are desirous of having a supply that they can recommend for the feeding of children. The medical societies have appointed a commission which draws up regu- 
lations to which each farmer must conform who desires to have his milk certified by the commission. The commission employ experts to aid in seeing that the rules are followed by the producers. A physician examines the attendants on the farm as to presence of contagious diseases and makes a general sanitary examination of the premises; a veterinarian examines the cows as to their health and applies the tuberculin test to the entire herd at frequent intervals; a bacteriologist examines the milk for numbers of bacteria and a chemist determines the amount of fat, milk solids, etc. These examinations act as a most efficient check on the methods followed on the farm since if any of the processes in the production and handling of the milk are slighted, it is certain to show in an increased number of bacteria.

The rules of the commission are usually very strict, giving in detail how the cows shall be cleaned and fed, how the stable shall be kept, the feed that can be used, the care and nature of the utensils, the handling of the milk, the toilet, and dress of the milkers. The number of bacteria allowed in certified milk is usually 10,000 per cubic centimeter. It requires the greatest attention to details of cleanliness to produce such milk. Certified milk sells from fifteen to thirty cents a quart. It is thus out of reach of the great mass of the people.

General improvement of milk supplies. There is a rapidly growing demand on the part of the general public that improvement in the general milk supplies should be made and the experience of practical dairymen has shown that clean, wholesome milk can be produced at a trifling additional expense, and that this clean milk, for all practical purposes, is as good as the much more expensive certified product. The cows, the feed, the milk- 
ing, and the delivery of the milk, need cost but a little more than is necessary in the production of the poorest grade of milk. A slight amount of labor applied at important points is the necessary thing. A stable that can be kept clean and so arranged that the cows can not get dirty, a little time expended in cleaning the animals preparatory to milking, judgment in the time of feeding, the use of a small topped pail, rapid and thorough cooling of the milk in a clean, well ventilated milk room, and storage in clean cans will enable any farmer to produce milk that will be as healthful and almost as desirable in every way as that which must be sold at a much higher price. It has been estimated that with a herd of ten cows producing one hundred quarts of milk per day that the additional labor and expense necessary to produce clean, healthful milk need not amount to more than onefourth of a cent per quart. With larger herds it will be less.

The highest grade of milk is a luxury, a very desirable one to be sure, but one that the mass of people must pass by. Efforts must be directed to the production of a milk that shall be clean and healthful, that can be sold at a price within the reach of the people and still give to the farmer an equitable return for his labor and interest on his capital.

City regulation of milk supplies. The control of cities over their milk supplies can not be better illustrated than by reproducing the rules adopted by the Chicago Board of Health with reference to the handling of the milk on the farm. At first these rules may seem complieated and cumbersome, but it will be noted that they contain nothing that is not essential to the production of good milk. 
Unclean milk not to enter the city of Chicago. All milk entering the city of Chicago and all milk sold, offered for sale, or received with the intention of selling or offering for sale must be clean, wholesome and uninfected with disease germs or anything liable to convey and transmit disease.

Unclean milk-Defined. All milk produced on farms or prepared, handled or otherwise treated on the premises or in places where the rules of the department are violated shall be declared unclean, unwholesome and infected. The sale of or offering for sale of such milk is prohibited.

Unclean milk condemned. All unclean, unwholesome or infected milk shall be condemned for human food. Such milk shall be returned to the producer and tagged with the "Department Condemned"' tag and condemnation slip shall be mailed to the shipper at once; if, following this, the said producer or shipper again sends. into the city unclean, unwholesome or infected milk, the same shall be condemned and rendered unfit for human food, by coloring or otherwise treating, or shall be poured into the sewer.

Condition and care of cows. The cows must be healthy and free from tuberculosis. If an examination by the dairy inspector shows evidence of excessive emaciation, glandular enlargement, nodular formations, mastitis, tumor, recent parturition, cough, dyspnoea, fever, pneumonia, exhaustion, lock jaw, black leg, anthrax, hemorrhagic septicemia, or any other infectious disease, or any evidence of tuberculosis, the milk of the herd shall be declared infected until the unhealthy cow or cows have been removed and until an acceptable statement 
from a recognized, licensed veterinarian or regular dairy inspector is filed with the Milk Division, showing that such suspicious cow or cows are free from infectious disease. Milk from cows reacting to tuberculin shall be rejected unless it shall have first been pasteurized at a temperature of $170^{\circ} \mathrm{F}$. or over for thirty seconds or longer in a stream not less than a quarter of an inch thick. Milk from cows fifteen days before and one week after calving shall be rejected. Cows must be kept as clean as possible on flanks, belly, udder, and tail. Long hair must be clipped from the udder and sufficiently from the tail to clear the ground. The feeding of slops, refuse of any distillery or brewery, glucose or any malt and ensilage that has been subject to fermentation, putrefaction or decomposition is prohibited. Pure water in sufficient quantities must be at hand at all times. The cows must not be overheated by hard driving, nor be allowed to stand in mud holes, dirty sloughs or ditches. Mud holes, dirty sloughs and ditches shall not be allowed to exist in the pastures or cow yards where cows for the production of milk are kept.

Condition of barnyard. The barnyard or cow barm must be kept reasonably clean and free from mud, soft manure and must be well drained. Piles and heaps of manure shall not be less than twenty-five feet away from any stable door or window between December first and April first and not less than three hundred feet away during the other months of the year.

Stable. The floors must be tight, preferably constructed of cement, and free from defects. The ceilings should be tight if a storage loft is kept above. The walls should be whitewashed every spring and fall and kept 
clean at all times. Each cow must have at least four hundred eubic feet of air space and there must be ample provision for movement of air and ventilation, so that the air never gets foul. At least two square feet of unobstrueted window glass space shall be provided for each cow. Soiled bedding must be removed daily and the manure must be removed from the stalls and open manure gutters twice a day. All bedding, removing of manure, sweeping and cleaning of mangers must be done at least one-half hour before milking. The stable must be reasonably free from flies.

Cats and dogs must not be permitted in the stable.

Milkers. Milkers should neither have nor come in contact with contagious diseases. Should any case of communicable disease such as typhoid fever, smallpox, scarlet fever, diphtheria, measles, or chicken pox occur on the dairy farm among the milkers or their families, the Division of Milk Inspection must be promptly notified.

Milking. Before each milking the udder should be wiped with a clean, damp cloth or washed with soap and water, if necessary. The hands should be washed before starting to milk and again well dried with a clean towel. The hands and teats should be kept dry during the milking. If they become moistened with milk they should be wiped dry with a clean towel. Suitable clean outer garments, such as overalls and jumpers, should be put on before milking. The milk stool must be clean. Milking should be done regularly, having the periods of as nearly equal length as possible. The first few streams from each teat should be rejected. The first half of the milk given should not be separated from the latter half or 
strippings and be sold separately. The top of the milk pail should be as small as possible, not larger than six or eight inches, to keep out dirt, and if anything falls in the milk, such as straw or manure, then the milk should be rejected. The milk from each cow should be removed from the stable immediately after it is obtained.

Milk cans and utensils. All utensils used in the production and shipping of milk, such as cans, covers, bottles, dippers, skimmers, measures, strainers, stirrers, etc., must be so constructed that all parts are absolutely free from places where milk can accumulate or soak in, so that it cannot be removed by simple washing. The surface coming in contact with milk and cream must be smooth and free from excessive rust. All utensils including cans must be kept scrupulously clean, inside and outside, at all times. They should be cleansed by washing with a brush and soap or washing powder and hot water and thorough rinsing. After this cleansing they should be sterilized with boiling water and then kept inverted in a place free from dust and flies. Strainers, whether metal, gauze or cotton must be absolutely clean when used for the straining of milk. Milk cans should be used for no other purpose. Bottle caps must be kept in clean, covered, dry and dust proof receptacles. All cans and utensils must be free from defects and rough or uneven surfaces.

Care of milk on the dairy farm. The room where utensils, milk pails, strainers and the milk are kept should be separated from both the house and the stable and be used only for dairy purposes. It should be kept neat, clean, well ventilated and free from flies and dust. No odds and ends or other unnecessary things should be 
stored in the milk room. The milk room must be free from odor.

Milk should be strained through a piece of clean linen or cotton, then it should be rapidly cooled to $50^{\circ} \mathrm{F}$. within two hours after milking and kept below that temperature until delivery. The evening milk must not be mixed with the morning milk and old milk must not be mixed with the fresh. The cans must be tightly closed when kept in the cooler and sealed when hauled to the milk platform. During this transportation they must bo covered and protected from the heat. This is best accomplished by carrying in a covered spring wagon. Cans should never be delivered too early to the milk platform. They should be covered with a damp cloth in the warm. weather while standing there.

Water supply. The water supply on the farm must: be ample and free from any danger of pollution with animal matter or refuse. Water used for the washing of cans and utensils must be free from all nitrites and not contain more than nine thousandths of one part of free ammonia and nine thousandths of one part of albuminoid ammonia in one hundred thousand parts. It must not contain more than one thousand bacteria per cubic centimeter and be free from pathogenic bacteria, including colon bacilli. Water from sloughs, ponds, ditches or other sources subject to contamination must never be used for the washing of cans or utensils. When typhoid fever occurs the use of the water on the farm must be discontinued for the washing of eans and utensils until it has been passed upon by the Director of the Laboratory of the Department of Health.

Sanitary standard for milk. All milk sold, offered for sale, kept with the intention of selling, or sent to the. 
eity for the purpose of selling must be free from dirt, foreign material, and sediment. Not more than a pereeptible sediment shall be left on a piece of white linen cloth four inches square when a quart of well mixed milk is strained through it. Milk on arrival in the city must not contain more than one million bacteria per cubic centimeter from May first to September thirtieth and not. over five hundred thousand per cubic centimeter between October first and April thirtieth. Milk for delivery to the consumer shall not contain an excessive number of bacteria. The sale of milk containing over three million bacteria per cubic centimeter is prohibited and the dealer selling or offering for sale such milk shall, after three examinations of his milk by the bacteriologist and showing bacterial counts above three million be prohibited from selling milk until the method of production and handling of his milk supply has been properly regulated by the department. The sale of milk containing tubercle, typhoid, diphtheria, and other pathogenic bacteria is prohibited. The sale of milk containing excessive numbers of putrefactive and gas-producing micro-organisms is prohibited. 


\section{RELATION OF BACTERIA TO DISEASE.}

\section{CHAPTER IX. \\ TRANSMISSIBLE DISEASES.}

Bacteria are classified according to their manner of nutrition into saprophytes and parasites. The saprophytic forms live on dead organic matter, the parasites live in the bodies of other living forms which may be either plants or animals. The form affected is known as the host, and the invading organism as the parasite. There are many forms of bacteria that may live in the animal body and cause no disturbance. Still other forms, known as pathogenic or disease-producing organisms, by their growth in the body of an animal cause changes that may injure the body or cause the death of the animal itself.

Transmissible diseases. Diseases traceable to such causes are capable of being communicated from one susceptible host to another, and are known as transmissible or communicable diseases. Many forms of disease are the result of some physiological disturbance of the body such as poor digestion, circulation, etc. These are not transmissible and no danger of spread from one animal to another exists. All transmissible diseases are caused by the infection of the proper host with the parasite, and by the growth of the parasite. In order that infection 
of a second host may oceur the parasite must escape from the body of the first in some manner. The parasitic bacteria can not, as a rule, readily multiply outside the body of the proper host. The opportunity for direct transmission from the sick animal to another healthy one is always so great that the infeetion is apt to be spread in this immediate way. Even where direct transmission from the one animal to another does not occur, the escape of the causal parasite into the outside environment permits of indirect infection through aceidental contamination of water, food and other objects.

Each disease is caused by a specifie organism. No other organism ean cause the disease and without the proper organism the disease is impossible. Each case of the disease thus demands a previous ease. Sometimes the relation between the two is easily established, often it can not be traced. In order to prevent or treat any transmissible disease, it is of advantage to know the cause of the disease, the nature of the causal organism, the way in which it enters the body of the animal, the portions of the body in which it grows, the changes it produces, and lastly, the ways in which it leaves the body of the affected animal. Unless these things are known, many things will be left undone that are necessary to prevent the spread of the disease. Often many things are done which have no importance in preventing the spread of the trouble.

Portals of entrance of bacteria. The bacteria enter the body of the animal in a number of ways. The skin acts as a protective layer to the body proper, and as long as it is intact prevents the entrance of bacteria into the body. As soon as it is eut, punctured or bruised, opportunity is offered for the entrance of bacteria. These are 
most frequently introduced into wounds with the dirt at the time the wound is made. A wound that does not bleed freely, or one that is not cleaned thoroughly, is more likely to prove a source of trouble than a cut which bleeds freely. The bites of insects are, with certain diseases, the way in which the organism is introduced into the body. Wounds may be on the exterior of the body, or on the interior surface, as in the mouth, stomach, or intestines.

The alimentary tract is the portal of entrance for some disease producing-bacteria, especially for those that produce those diseases known as intestinal diseases, as hog cholera and chicken cholera. In these diseases the bacteria grow in the intestines. In other diseases the causal organisms are able to pass through the walls of the intestines and thus get into the blood and lymph to be carried to various parts of the body.

The air passages and lungs form a third portal of entrance. The bacteria in the dust of the air lodge in the various parts of the air passages or in the lungs. Influenza, pneumonia, and tuberculosis may be acquired in this way.

Exits of bacteria from the body. The bacteria once in the body grow in various parts, depending on the nature of the disease. In most diseases they pass, in greater or less numbers, from the body of the animal before death occurs. They are thrown off in the manure in the case of intestinal diseases, such as hog cholera; in the urine; in the sputum, as in tuberculosis and pneumonia; in the contents of boils and ulcers, as in glanders and pyogenic troubles; in the milk when the udder is diseased, as in garget and tuberculosis, and in the blood drawn from the body by sucking insects. After death by the 
decomposition of the carcass, the bacteria are set free unless, as frequently happens, the process of putrefaction destroys them.

Spread of pathogenic bacteria. The bacteria are spread from place to place by insects which have bitten the living animal or have fed on the carcass; by birds, and by carnivorous animals, as dogs. The bacteria may be carried long distances in water, or by wind as dust in the air; on the clothes and shoes of attendants; on farm implements as hoes, shovels, etc.; and by the shipment of infected objects such as hides.

The most important manner in which the disease-producing bacteria are spread is through the transfer of diseased animals from place to place. All of our important transmissible diseases have been imported to this country in the bodies of animals. Constant watch has to be maintained to prevent the introduction into this country of some diseases that are widespread in Europe. such as foot and mouth disease and contagious pleuropneumonia of cattle.

Susceptibility to transmissible diseases. In order that transmissible diseases may develop, it is necessary to have the causal organism enter the body of a susceptible animal host. Not all animals are susceptible to any disease. When an animal does not afford a suitable medium for the growth of the parasite, it is said to be immune. Such an immunity is "natural." Again immunity may be "artificial," i. e., induced by a natural attack of the disease, or by the introduction of some immunizing substance into the body, as in the employment of vaccines in black leg and anthrax. Some diseases affect but a single kind of animal, as typhoid fever in man, or hog cholera in hogs. Again a large number of kinds may be 
subject to the disease, as with tuberculosis which naturally occurs in man, cattle, hogs, fowls, and many other animals.

Period of incubation of transmissible diseases. A period always elapses between the time of the entrance of the bacteria into the body and the first signs of illness. This is called the "period of incubation" of the disease. It may be but a few days in length, as in the case of anthrax, or from several weeks to months, as with tuberculosis.

Lesions of the disease. The bacteria produce in the body of the affected animal more or less characteristic symptoms and changes. By these alone, one is often able to determine the disease present. The changes in the different organs of the body from their normal condition, due to the action of the disease-producing organism, are known as the "lesions." A post-mortem examination of any animal that has died of a suspected transmissible disease should always be made so as to render more certain a correct diagnosis. Precautionary measures which will be described later should, however, be taken in making such examinations, in order to prevent further trouble.

The various transmissible diseases differ greatly in the rapidity with which they progress in the animal. Anthrax usually kills the animal in a few days, while with tuberculosis an animal may live for years.

Necessity of diagnosis of transmissible disease. With those diseases caused by some form of bodily disturbance, it is of small importance, except for determining the kind of treatment to apply, whether a correct diagnosis of the disease is made or not, since the disease can not spread to 
the other members of the herd. With the contagious diseases, it is of the greatest importance that an early and correct diagnosis of the trouble be made so that proper means may be taken to prevent the spread of the disease in the herd.

In the following pages the general characteristies of the transmissible diseases most likely to be met by the stockman in his herd and flocks are given. The farmer must usually rely for a diagnosis of any disease on the experienced veterinarian who must often call to his aid the facilities of a bacteriological laboratory.

Treatment and prevention of transmissible diseases. With most of the transmissible diseases but little can be done so far as treatment of the infected animal is concerned. Especially is this true when the period of incubation of the disease is past and the causal organism is established in the body of the animal. The disease must be allowed to run its course in the individual animal. Much can be done in preventing the disease, either in keeping it out of the herds and flocks, or in limiting its spread when once introduced. The transmissible diseases are often called preventable diseases. The prevention is accomplished by not allowing contact of the animals with any materials containing the causal organism. In order to do this in an intelligent manner, it must be known with certainty which disease is present; the nature of the organism; its manner of entering, and leaving the animal body, etc.

The farmer should have a sufficient knowledge of the nature of the various diseases so that he may know the proper steps to take, in order to protect his animals in outbreaks of the different transmissible diseases. 


\section{ANTHRAX, BLACK LEG, HEMORRHAGIC SEPTI- CEMIA AND CORN STALK DISEASE.}

The disease of anthrax is much more important in Europe than in this country. It is, however, quite common in Mississippi, Louisiana, and Delaware and in many other states, it occurs at irregular intervals. It is a matter of much importance to have the disease break out in a district or on a farm, since it is very difficult to rid an infected area of the disease, if it once becomes established.

The disease is one which affects primarily sheep, cattle, and horses, although other domestic animals as hogs, dogs, and cats may acquire it. Human beings may be affected with it. The relation of bacteria to disease was first proven in the case of anthrax. The organism can be easily grown in the laboratory on a large number of substances. While the anthrax bacillus can grow in the animal body in the absence of free oxygen, it can not form spores except in contact with the oxygen of the air.

Channels of infection. The bacteria enter the body in a number of ways. If the food or water is contaminated, they enter through the intestinal wall. The disease may be acquired from infected hay or on the pasture. The organisms may enter the body by way of the lungs, in the dust of the air, or may be introduced through wounds, especially by the bites of flies that have had access to the carcass or body of an affected animal. 
It is thought that the horse fly is one of the chief means by which the disease is spread among the plantation mules of the southern states.

Symptoms. The disease appears in two types, in one of which there are no external signs of trouble, in the other swellings or carbuncles develop on the surface of the body. The type showing no localization on the surface of the body is most common in cattle and sheep, and is due to infection by way of the intestines. When the organisms have been introduced through a wound, they may develop at the point of introduction, forming a tumor which is at first hard, hot, and painful. It rapidly increases in size and becomes cold and painless due to the death of the tissues. If the tumor is opened a dark tarlike exudate is noted. The tumors may develop in the throat, especially in hogs and dogs. Gangrene often appears in the tumor, due to secondary infection with putrefactive bacteria.

The disease varies widely in its duration. The first animals to die in an outbreak may show no symptoms whatever, but may be found dead in the pasture. Others may show signs of illness for a few hours, and the last animals to die may have had the disease for several days. In the less rapid forms of the disease, the temperature rises to $105^{\circ}-108^{\circ} \mathrm{F}$. The animal may be restless, stamping the ground, running about, and at last going into convulsions, which are followed by death. If the lungs are affected, the animal has difficulty in breathing. In case the carbuncles are noted, the duration of the disease is likely to be longer than when the infection is more general.

Post-mortem examination. The most prominent changes to be noted on post-mortem examination are the 
enlarged spleen (milt) which is often several times its normal size, and much darker in color than normally. It is soft and friable. The blood is not bright red, but is of a dark, tarry appearance, and does not coagulate as does normal blood. Shortly before death, a dark bloody exudate may be noted coming from the natural openings of the body, nose, mouth, and anus. The urine may also be dark in color. The intestines may be affected, in which case the contents are bloody. The carcass begins to putrefy very soon and the stiffness of the body noted after death from other causes is absent.

Differential diagnosis. It is very important to differentiate this disease from others, such as black leg and hemorrhagic septicaemia, which are often mistaken for anthrax. The precautions that must be taken to prevent further spread in the herd differ from those to be employed with these diseases. On account of the suddenness of the death of the first animals affected, the farmer is likely to think they were poisoned or were killed by lightning. The changes peculiar to the disease may be absent, in which case a bacteriological examination is necessary in order to establish the nature of the disease.

General precautions. The bacteria found in immense numbers in the blood, form spores as soon as the blood is allowed to escape from the body, as happens in making a post-mortem examination. If the body is unopened spores can not form. As previously noted there is often a discharge from the natural openings of the body. This will contain the organisms. The spot where the animal dies is thus certain to be infected. The spores will remain in the soil of pastures and fields for years, and such a contaminated pasture can not be used with safety.

In order to prevent the general spread of the disease, 
and the infection of pastures, as well as to prevent the danger of accidental infection the greatest precautions should be taken in the handling of anthrax carcasses. The carcass should not be skinned, or dragged on the ground to place of burial, as this treatment will give opportunity for dispersal of spores.

If there is any reason to suspect that an animal has died of anthrax, an examination should be made, by a veterinarian if possible. A small portion of the spleen or preferably an ear should be sent to some laboratory* for diagnosis in case the decision can not be made on the results of the post-mortem examination alone. Tissues oî all kinds that are to be sent to a laboratory for examination should be placed in a clean vessel that can be sealed tightly such as a fruit jar. This should be packed in sawdust or shavings and ice so that it may reach the laboratory in such a condition that an examination can be made.

After examination the carcass should, if possible, be burned. If this is not possible, it should be buried deeply, covering well with lime before replacing the dirt. The place of burial should be protected by fencing off the same if it happens to be in the plasture. If the disease of anthrax breaks out while the cattle are on the pasture, all those that show no signs of illness should be at once removed and vaccinated. The temperatures of the healthy animals should be taken morning and evening for two weeks, and any animals showing an abnormally high temperature, $105^{\circ} \mathrm{F}$. or higher, should be removed at once from the herd.

* Many states maintain laboratories under the direction of the Live Stock Sanitary Boards or Experiment Stations for the examination of such material. 
Vaccination against anthrax. There are a number of infectious diseases which affect, as a rule, the individual but once. Measles, mumps, and small pox are examples of such diseases in man. The first attack protects the individual against a subsequent one. The exact reason for this protection, which may last during the life of the individual or for a shorter time, is not fully known. This immunity is called "acquired" as opposed to "natural" immunity. Jenner was the first to show in the case of small pox that protection might be produced by artificially inoculating the individual with a weakened virus, that this inoculation was without danger to the individual, and yet protected him from acquiring the virulent disease. The small pox virus is weakened by passing it through the body of a calf so that it is no longer able to produce a general infection but only a sore at the point of inoculation. Later Pasteur discovered that certain other diseases caused by bacteria could be prevented by vaccination. In all cases the vaccine is prepared by the use of the specific organism of the disease in question that has been artificially weakened or reduced in virulence in a variety of ways. These methods will be given under the various diseases for which vaccines are employed.

In the case of anthrax the vaccine is prepared by growing the anthrax bacillus at a high temperature for several days. This decreases its virulence. It is desirable to have a vaccine of a virulence sufficient to produce a mild fever in the animal, or there will be no immunity produced.

The vaccine, as used is prepared in a variety of ways. It should be applied only by an experienced veterinarian. Care must be exercised in its use, because in it are living 
organisms, which, under some conditions it is claimed may regain their virulence. The protection afforded by the vaccination lasts less than a year, hence if cattle are to be turned onto infected pastures, the process of vaccination must be repeated yearly.

The disease is often spread from one place to another by means of infected hides, wool, and bristles. Hides imported into this country have been shown to be the cause of a number of outbreaks. The disease is spread from tannery refuse which is usually turned into flowing streams. Animals may become infected by drinking the water or by grazing on lands subject to overflow. Epidemies of anthrax have been caused in this manner in Wisconsin, Pennsylvania, and Dèlaware.

The disease occurs in human beings, especially in the case of tannery operators and workers in woolen mills and brush factories. The spores are breathed in or are introduced into wounds. Anthrax is often called "wool sorters" disease in human beings. If the infection is through a wound, a carbuncle usually results, if the infection is by way of the lungs the disease is often of a generalized and fatal type.

The farmer who suspects anthrax amongst his animals can not be too careful. The dead animal should be examined but should be opened only at the place where the carcass is to be disposed of so as to prevent the infection of yards, barns and fields. The person making the examination should see that his hands are free from abrasions or cuts. It is helpful to have the hands coated with lard or vaseline. Care should be taken to prevent the contamination of shoes and clothing. The utensils used in the examination should be disinfected at once, preferably by heating them in a fire, or by boiling in 
water for an hour. The carcass should be disposed of at once after opening so that flies shall not have access to the blood.

It should also be remembered that the urine, feces, and discharges from the nostrils may contain the organisms. Barns may thus become contaminated, and where spores form, infection persists for long periods. The milk may sometimes contain the organisms just prior to the death of the animal.

\section{BLACK LEG.}

Black leg or symptomatic anthrax, as it is often called, because some of the symptoms and lesions resemble those of anthrax is a disease of importance, especially in the western states where cattle are given a wide range. While found in the majority of the states, in other than the range states it occurs only in isolated localities.

Animals affected. The animals affected are cattle, sheep, and goats, the latter two very infrequently. No other domestic animal is susceptible to the disease nor is man. It is primarily a disease of young cattle, between the age of six months and two years, and is most often noted among the best nourished animals of the herd. Purebred and grade animals are more susceptible than common stock of the range. The "long horn" of the Texas ranges did not easily acquire black leg but with the introduction of purebred stock the disease has increased greatly in amount. In the northern states it is most frequent from April to September, in the south it occurs at all times of the year.

Symptoms. The organism is supposed to enter the body through wounds on the skin or mucous membranes of the mouth and intestines. So far as is known the bac- 
teria do not enter the body in the feed or air. The period of incubation of the disease is not.known, but it is supposed to be very short. The symptoms resemble quite closely those of anthrax. The animal has a fever and suffers loss of appetite and rumination. Tumors or carbuncles may appear on the surface of the body, especially on the thighs and shoulders, hut not below the knee or hock joints or on the tail. The swelling is at first small and painful. Later it increases in size, and becomes cold and painless, owing to the death of the tissue. When the hand is passed over the swelling, gas can be noted in the tissue, making a crackling sound under pressure. When opened a dark frothy liquid exudes which has a disagreeable odor. The disease is usually fatal. The period of illness one to three days.

Post-mortem examination. In a post-mortem examination the muscles about the tumors appear dark in color, hence the name "black leg." The muscle fibres of the tissue affected by the carbuncle are forced apart by the gas. The production of gas in the body continues after death, producing a bloated condition of the carcass. The tumors are much like those found in anthrax, except that in anthrax tumors no gas is present.

The blood in black leg is normal in color and in coagulating properties, the spleen is not enlarged. These often enable it to be distinguished from anthrax.

General precautions. The organism causing black leg is an anaerobic one. It produces spores in the carcass of the dead animal, even when unopened, as oxygen is not necessary for spore formation. If the body is apened and the soil polluted by blood, the organisms will persist for a long time in the field. The same care should be taken as in anthrax in making a post-mortem 
examination, to prevent soil contamination. There is not the same danger, however, to the person making the examination as the disease does not affect man. The disposal of the carcass should be done either by burning or burying it deeply in a place where it can not be washed out or dogs dig it out. The skin should not be removed. The place where the animal lay at the time of death should be disinfected.

If the disease breaks out in a herd, the animals that show no signs of illness should be at once removed from the pasture while the sick ones are confined to a small range. The healthy animals should be vaccinated. Here as in anthrax the vaccine contains the disease-producing bacteria in a weakened form. The vaccine is made by taking the meat from a fresh black-leg tumor, pounding it in a mortar with a little water, and squeezing the pulp through a cloth. This filtrate is allowed to dry. It can be kept in this dry form for a long time. The organism is weakened by heating this powder to about $210^{\circ} \mathrm{F}$. for 6 hours. It is prepared for injection into the animal by suspending the powder in water. A definite mixture is made, one cubic centimeter of which is injected beneath the skin of the animal. Some of the commercial firms put up the vaccine in the form of a small pellet which can be introduced readily beneath the skin of the animal by means of a special syringe. Another form consists of a bunch of threads which are inserted beneath the skin by a special instrument. The vaccine is used especially on the ranges, where large numbers of animals must be vaccinated, and it is desirable to have the vaccine in as convenient form as possible.

The Bureau of Animal Industry of the U. S. Department of Agriculture sends the vaccine to the farmers 
whose herds are affected. In 1907, 1,200,000 doses were sent out. Its use has been very successful. On the large ranges before vaccination was carried out the loss amounted to about 10 per cent. of the annual calf crop. By vaccination the loss has been reduced to less than 0.5 per cent.

\section{HEMORRHAGIC SEPTICEMIA.}

By "septicemia" is meant a disease in which the bacteria are found especially in the blood. The phrase "blood poisoning" is also used to refer to such diseases. Anthrax may be called a septicemic disease for the organisms are found in every drop of blood. Hemorrhagic septicemia is a type of blood-poisoning which is characterized by hemorrhages in various parts of the body. By a hemorrhage is meant the passage of the blood out of the blood vessels into the tissue.

This disease is found in all parts of the world. In our own country it occurs most frequently in the upper Mississippi valley. In Europe it has caused great losses. among the wild animals, deer and wild-boar.

The way in which it is introduced into a herd is unknown, as well as its passage from one animal to another. The normal habitat of the bacteria is also unknown. The disease is likely to appear suddenly in a herd, destroy a large part of the same and disappear as mysteriously as it came.

The rapidity of its appearance and the suddenness with which the animals die, together with the helplessness of the owner to contend with it, make it a disease much to be dreaded. Frequently the animals die without any previous symptoms of illness. This may lead the owner to think the animals have been poisoned. 
Cows which gave the usual amount of milk in the morning, may give none at night, and be found dead by the next morning. The symptoms are often quite similar to those of milk fever. The animal is weak, staggers in walking, and the extremities are cold. The duration of the disease is, as indicated, short. Recovery is rare.

Post-mortem examination. On post-mortem examination red spots from the size of the head of a pin to several inches in diameter are found beneath the skin. Hemorrhagic areas are also found on the heart, stomach, and intestines. The blood is red and coagulates in a normal manner. The spleen is also normal. The disease is often confused with anthrax on account of the sudden death of the animals. It is, however, very important that a correct diagnosis be made, for the methods of treatment and prevention are different. The enlarged spleen and the dark colored blood in anthrax serve, usually, to differentiate that disease from hemorrhagic septicemia, while such tumors as are found in black leg do not occur in this disease. Some times it is difficult to tell which disease is present from an examination of the carcass. Recourse must then be had to bacteriological examination of the blood, a sample of which should be sent to the state authorities having charge of the live stock interests. No treatment is of any value, no vaccine can be used nor an antitoxin as in the case of tetanus.

In order to prevent the spread of the disease, in the herd, it is necessary to isolate each animal from every other animal of the herd. This can be done by staking the animals out. They should be removed from the infected pasture to a fresh one or to a meadow and tied with ropes.

The carcasses should be burned or buried deeply and 
every precaution should be taken to prevent the spread of the disease. If animals die in the barn, the litter should be burned and the stable cleaned and disinfected. The organism does not form spores, hence is easily destroyed in stables through the use of disinfectants.

\section{CORN STALK DISEASE.}

In those sections of the country in which it is the custom to pick the corn from the standing stalks, and then turn cattle into the fields, a disease known as "corn stalk disease" is sometimes encountered. The trouble appears soon after the cattle are turned into the corn field ( 4 to 10 days). It appears without warning and kills the cattle very quickly. Animals that seem to be well at night are found dead in the morming. Usually all of the animals that die of this trouble are lost in a single day or at least in a few days.

On account of the suddenness with which death occurs, and the large losses which follow in a short time, it is often taken for a specific contagious disease, especially for anthrax, black leg, or hemorrhagic septicaemia. It is important to differentiate the disease from those mentioned. This can be done by the relation of the appearance of the disease in the herd to the period of allowing the cattle access to the stalks, and by the fact that in corn-stalk disease the tissues appear normal on post-mortem examination. 


\section{CHAPTER XI.}

\section{TUBERCULOSIS.}

This disease is known by many names, consumption, or phthisis in man, grapes or pearl disease in cattle; it is also often called the great "white plague." It is characterised by the formation in the body of nodules or tubercles, hence the name tuberculosis. It is the most important disease of man, as well of domestic animals. It causes one seventh of all deaths of human beings, and a much larger proportion of the deaths of people between the ages of twenty and forty years.

Animals affected. All of the domestic animals may be affected, but it is most prevalent amongst cattle, hogs, and hens; much less so amongst horses, sheep, dogs and cats. From an economic or a hygienic standpoint, consideration need be given to the disease only as it appears in cattle, hogs, and fowls.

Geographical distribution of tuberculosis. The disease is world-wide in the case of man and almost equally. so in cattle. All the important special breeds of cattle have originated in Northwestern Europe; from here they have been carried to all parts of the world, and they have carried with them this disease. The native cattle of most countries were free from tuberculosis until the improved breeds were introduced. The islands of Jersey and Guernsey are free from bovine tuberculosis, and are kept free because no live cattle are imported. 
In the European countries, where dairying has long been carried on, the disease is very widespread. In some of the German states 30 per cent of the cattle are diseased; in Belgium 48 per cent; in Denmark after fifteen years of warfare against it, the percentage of dairy cows affected has been reduced from 40 to 10 per cent; in England 35 per cent of the eattle are affected. In some of our eastern states, as Massachusetts, 26 per cent of the dairy cows have the disease. The amount of the disease is less in the western states, probably from 5 to 10 per cent of the mileh cows of Wisconsin, Minnesota, Iowa and Illinois are affected.

It is not evenly distributed, but is most prevalent in those districts where improved dairying has been longest earried on, and where buying and selling of milch cows is general, as in the districts furnishing milk to the cities. It is more often found in pure-bred herds than in those of common stock, not because pure-bred cattle are more susceptible, but because more animals are bought into and sold from such herds. There is little or no difference in the susceptibility of the various breeds; Jerseys are free from it on the island of Jersey, but acquire it, when brought in contact with diseased cattle. The beefbreeds are as easily infected as any of the dairy breeds. It is more often present in large herds than in small ones, as each animal purchased may be the means of introducing the disease into the herd.

Distribution and appearance of diseased tissues. The disease is commonly associated ${ }^{*}$ ith an affection of the lungs and indeed this organ is most often attacked. Every part of the body, however, may be diseased-heart, liver, spleen, muscles, brain, and skin may be affected. The lymph glands that are found in the neck, along 
the windpipe, and close to the intestine are usually the first to be affected. In making a post-mortem examination of the suspected animal, the parts that should be examined are the lungs, the lymph glands mentioned above, liver and the spleen.

The tubercles vary greatly in size, from a pinhead to. the size of a hazelnut or walnut. When opened, the smaller tubercles are usually of a light gray color throughout, or may show at the center a yellowish spot. The larger tubercles will usually contain yellowish.

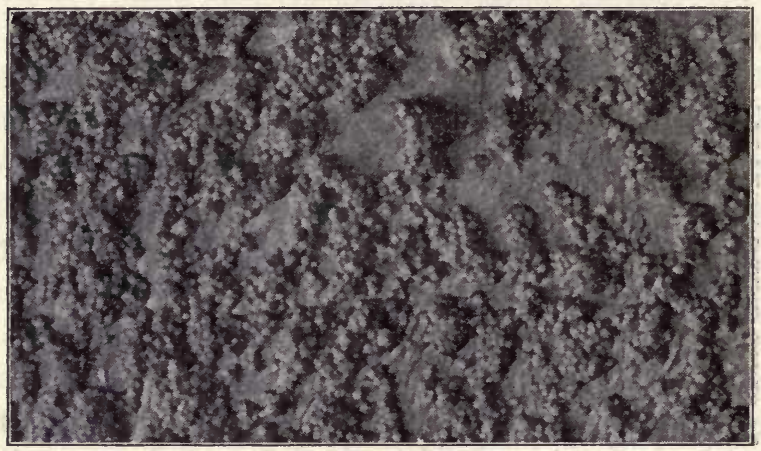

Fig. 12.-Tliberculous Omentum.

The omentum, a' membrane of the abdominal cavity, is normally smooth and thin. It is here studded with masses of small tubercles. From a generalized case of bovine tuberculosis.

material and in many of the organs, as in the liver, spleen, and lungs, tubercular abscesses of varying size may be formed. Some of the lymph glands become very greatly enlarged. They may be filled with creamy pus, or with a hard, gritty, yellowish substance, which is produced by the accumulation of lime salts. On account of the yellow granular appearance, the contents 
are often said to look like corn meal. The healthy lymph glands are of uniform color throughout, or in the older animals they may be filled with a black pigment. The tuberculous gland will, on section, show a larger or smaller diseased area, apparent by its yellow color.

The lungs of a healthy animal are light pink in color and spongy in texture; when tuberculous, the tissue is consolidated, abscesses or affected areas appearing in the lung tissue or even raised from the surface. The bronchial glands located at the fork of the windpipe and imbedded in the lung tissue are often early affected. The diseased organs are usually much enlarged and owing to the consolidation of tissue may be very heavy.

The udder is sometimes affected. The normal udder should be uniformly soft; the tuberculous udder often contains hard bunches or nodules. As the disease progresses an entire quarter may become enlarged, and very hard. There is no fever or painful swelling as in garget. Tuberculosis of the udder is important because the milk is then certain to contain the tubercle organisms.

The bacteria are discharged from the body of an animal in a number of ways. The tubercles in the lungs may discharge their contents into the air passages; the material is coughed up, a portion ejected from the mouth during the act of coughing, the major part being swallowed. The sputum is digested, the tuberclo bacilli set free, and they pass unharmed through the stomach and intestines and are voided with the manure. When the intestines are involved, the organisms also appear in the manure. From diseased kidneys or bladder, they pass off in the urine, and from the udder, in the milk. Animals shedding organisms in this way are 
said to have "open" tuberculosis, and are a special menace to the remainder of the herd. When the disease is confined to parts of the body that have no external opening, as lymph glands, the cow is said to have "closed" tuberculosis. As long as the disease remains "closed," the animal is not a source of danger. It is impossible to foretell when the "closed" type will change to the "open," as it is certain to do sooner or later with the continued development of the disease. Hence every affected animal must be considered a menace, present or potential, to the herd and to the public health.

Infection of the animal. The bacteria that come from diseased animals are carried into healthy animals in the dust from polluted mangers and dried manure. The dust may enter the lungs or it may lodge in the throat. The food may be soiled by the sputum of an animal, or by dust. The milk fed to calves and hogs may contain the bacteria, which then pass through the walls of the intestine into the lymph and blood streams and are carried to various parts of the body, especially the lungs and lymphatic glands. For this reason these are the organs most often affected. Hogs acquire the disease very readily when fed on contaminated milk, a single feeding of milk containing many tubercle bacilli suffices to infect hogs. Because of the content of manure in tubercle organisms, hogs running after cattle in the feed-lot are as likely to be diseased as those fed on skim milk. Animals may acquire the disease by contact with a diseased animal, as for instance by licking each other. Very rarely are the reproductive organs affected, and the calves from tuberculous dams are usually healthy. Because of this fact, it is possible to 
raise healthy ealves from diseased mothers, by what is known as the Bang system, which will be described later.

Infection of the herd. The most frequent way in which the disease is introduced into a herd is by the purchase of a tuberculous animal. The larger the number of animals purchased, the more likely is the disease to be introduced. The animal purchased may appear healthy and may not at the moment be a source of danger, but is certain in time to become a center from which the disease will spread throughout the herd. As was stated, pure-bred herds are often diseased. All too often has a man introduced the disease into his herd through his efforts to improve his stock by the prehase of a pure-bred sire.

The farmer should know the condition of every animal he buys. He will use great precaution to avoid buying an unsound horse, but the purchase of such an animal is not to be compared so far as probable future loss is concerned, to the purchase of a tuberculous cow, for the trouble from which the horse suffers is not likely to spread, while tuberculosis will surely infect others.

Buy pure-bred animals from honest breeders whose herds are known to be free from tuberculosis and from no others, even though they will guarantee the condition of the animals.

The feeding of creamery skim milk and of whey is another potent means of introducing the disease into the herd. The patron of a creamery or cheese factory carries to his calves and hogs a mixture of the milk of all the other patrons. In case there are tuberculous cows in any of the herds, the milk may contain tubercle bacilli. The farmer can protect his herd from such infection by the use of a farm separator, or by heating 
the skim milk and whey to $160^{\circ} \mathrm{F}$. before using. In Denmark and Germany such a treatment of skim milk and whey by the creameries and cheese factories is made compulsory. Some of the States have similar laws. It is a process to which no one should object. The butter and cheese maker will find himself repaid in the improved quality of the milk furnished him, since the milk cans are not polluted with injurious bacteria from dirty whey tanks. The farmer will find that the heated whey and milk will keep longer, hence will be sweet when fed.

Spread of the disease in the herd. Any animal with open tuberculosis is giving off the tubercle bacilli, thus exposing the remainder of the herd to infection. The disease may spread slowly at first, but as one animal after another becomes a new center from which the organisms are furnished, the rate of spread increases. The rate of distribution is well shown in the following case: Twelve healthy animals were placed in a stable occupied by a diseased herd. In six months nine had become infected and the disease had made such headway that four did not pass inspection when slaughtered and examined by the Federal meat inspectors.

The conditions obtaining in the barn with reference to light and ventilation will exert a great influence on the rate of dissemination in the herd. If the air is poor and the animals are forced to breathe it more or less continuously during the winter, their ability to ward off the disease is reduced. Plenty of pure air is necessary for cattle as for man.

The most important phase of the modern methods of curing tuberculosis in human beings is to live out of doors, to sleep out of doors, summer and winter. Light 
has an injurious effect on bacteria, destroying them within a few moments when they are directly exposed to it. It has been shown by direct experiment that the disease will spread more rapidly in unsanitary barns, than in those which are well lighted and ventilated. The use of whitewash twice a year is advisable as it has a disinfecting action and makes the stable lighter.

Symptoms of the disease. In the early stages there are no definite symptoms. The disease starts in some part of the body, usually in the lymph glands, and may make headway very slowly: For years it may be confined to a single gland, but sooner or later on account of some condition that may temporarily impair the resistance of the animal, such as calving, the disease develops more rapidly. In the last stages the animal becomes emaciated, the hair is rough, the eyes sunken, the head extended; the appetite may be good, but the food apparently has no effect. If the lungs are involved the animal may cough, especially when forced to move rapidly after resting. If there are hard painless swellings in the region of the throat or shoulders, the animal may be suspected of tuberculosis. If there are hard nodules in the udder; if one or more quarters are enlarged and hard, but painless and cold, or if the lymph glands at the top and rear of the hind quarters of the udder are enlarged, suspicion may be aroused. It is absolutely impossible for the most experienced veterinarian, in the great majority of cases, to tell from a physical examination alone, whether the animal has tuberculosis or not, or predict the stage of the disease. An animal may be the picture of health and be as great a source of danger as one in the last stages. 
Tuberculin test. The only way by which it can be determined with certainty whether an animal has tuberculosis or not is by the use of the tuberculin test. Tuberculin is prepared in bacteriological laboratories by growing the tubercle organisms in beef broth containing glycerin. The organism produces a substance in the broth, which, when injected beneath the skin, has a peculiar effect on a diseased animal, causing a fever for a few hours; while in the healthy animal it has no appreciable effect. The beef broth is heated, and filtered



Fig. 13.-A Tuberculous Animal.

A cow that has had the disease for five years.

through porcelain, so that the tuberculin as used contains neither living or dead bacilli, but is simply an extract of their cells. It cannot produce the disease in healthy animals nor does it cause the disease to spread in affected animals.

The test is made by taking a series of temperature readings on the animal, injecting the tuberculin beneath 
the skin, and beginning ten hours later, a second series of temperature readings is taken. From a comparison of the temperatures before and after the injection of tuberculin, the condition of the individual animal is determined.

Details of making the tuberculin test. The first series of temperatures must be taken in order to deter-



Fig. 14.-A Tuberculous Animal. An advanced case of generalized tuberculosis. Six weeks before the photograph was taken the animal was in as fine condition as the one shown in Fig. 13.

mine the normal temperature of the animal, since the temperature of the cow is not constant like that of man, but varies from hour to hour in the same animal and in different individuals. The average temperature of healthy milch cows ranges from $101^{\circ}$ to $102^{\circ} \mathrm{F}$. The temperature of fat stock and calves is higher; of old and 
poor cows lower. The variation in the normal individual animal may range from $99^{\circ} \mathrm{F}$. to $103^{\circ} \mathrm{F}$. The variation that may occur in the temperature of a well-kept healthy animal is shown in the following table in which are given the temperatures of two healthy cows for twenty-four hours, together with the rate of pulse and the number of respirations per minute. Exercise, excitement, and hot weather increase the temperature. A hot spell causes a rise of two and sometimes four degrees. The drinking of cold water lowers the temperature.

Temperature, Rate of Pulse, and Respirations per Minute.

\begin{tabular}{|c|c|c|c|c|c|c|c|}
\hline \multirow{2}{*}{\multicolumn{2}{|c|}{ Hour }} & \multicolumn{3}{|c|}{ Cow No. 1} & \multicolumn{3}{|c|}{ Cow No. 2} \\
\hline & & $\begin{array}{l}\text { Tempera- } \\
\text { ture }\end{array}$ & Pulse & Resp. & $\begin{array}{c}\text { Tempera- } \\
\text { ture }\end{array}$ & Pulse & Resp \\
\hline $\begin{aligned} 10 \mathrm{~A} . \\
12 \mathrm{~A} . \\
2 \mathrm{P} \\
4 \mathrm{P} . \\
6 \mathrm{P} . \\
8 \mathrm{P} . \\
10 \mathrm{P} . \\
12 \mathrm{P} . \\
2 \mathrm{~A} . \\
4 \mathrm{~A} . \\
6 \mathrm{~A} . \\
8 \mathrm{~A} .\end{aligned}$ &  & $\begin{array}{l}99.5^{\circ} \mathrm{F} \\
100.8 \\
101.6 \\
103 . \\
103.1 \\
103 . \\
102 . \\
102.5 \\
102.4 \\
102.2 \\
101.8 \\
102.5\end{array}$ & $\begin{array}{l}66 \\
54 \\
48 \\
66 \\
57 \\
56 \\
60 \\
56 \\
64 \\
54 \\
60 \\
56\end{array}$ & $\begin{array}{l}18 \\
15 \\
15 \\
24 \\
18 \\
16 \\
20 \\
16 \\
18 \\
24 \\
18 \\
16 \\
\end{array}$ & $\begin{array}{l}98.6^{\circ} \mathrm{F} \\
99.4 \\
100.2 \\
102.7 \\
103 . \\
102 . \\
102 . \\
101.6 \\
102.2 \\
101.5 \\
102.2 \\
103.2\end{array}$ & $\begin{array}{l}60 \\
54 \\
54 \\
72 \\
60 \\
60 \\
50 \\
54 \\
58 \\
60 \\
60 \\
60\end{array}$ & $\begin{array}{l}15 \\
15 \\
18 \\
24 \\
27 \\
24 \\
18 \\
20 \\
18 \\
24 \\
20 \\
18 \\
\end{array}$ \\
\hline
\end{tabular}

The temperature is taken in the rectum by means of a clinical or fever thermometer, similar to those used by physicians. The mercury in these thermometers does not run down, but stays at the highest point reached, i. e., registers, until shaken down. Veterinary thermometers of heavy glass with a ring at the end are best; a string is attached to the ring and to a small paper clamp. When the thermometer is inserted in the animal, the clamp is attached to the long hair at the base of the tail. In this way the thermometer, if ejected by the animal, will not be lost or broken on the floor. 
The mercury should always be shaken down below $98^{\circ}$ $\mathrm{F}$. before the thermometer is inserted. If the animal objects to the insertion, scratching her back with a card will attract her attention and no difficulty be met. Vaseline may be used on the instrument to aid in its insertion.

The temperature should be taken four times at intervals of 2 hours, before the injection of the tuberculin. The injection of the tuberculin is made by the use of a well-made hypodermic syringe. The injection is made usually back of the shoulder blade, but may be made wherever the skin is loose and thin. The needle is thrust through the skin at right angles, but care should be taken not to push it into the muscular tissue below. A syringe with a needle that slips on, rather than one that screws on to the barrel is preferable, since the needle can be inserted and the syringe then attached. The needle should be of 15 or 17 wire guage; strong needles are needed for this kind of work. It is well to sterilize the syringe before using by placing it in a pan of cold water and bringing the water to a boil.

Animals whose temperatures are abnormal, say $103^{\circ}$ F., should not be injected, neither is the test as reliable when applied to animals about to calve, or those in heat or to young calves less than 3 months old.

The dose of tuberculin depends upon the size of the animal. That distributed under the auspices of the United States Department of Agriculture is diluted, ready for use and requires 2 c c. (40 drops) per 1000 pounds live weight. The amount of the commercial tuberculin to be used is always stated on the package.

The temperature records are commenced 8 to 10 hours after the injection, which is usually made in the evening. 
The taking of temperatures should be continued at least. until 18 hours after inoculation or until there is a permanent decline toward the normal.

The animals should be kept in as normal a condition as possible during the test. Care should be taken not to excite them as this will cause the temperature to rise. It is usually preferable to make the test at the time the cattle are kept in the stable, e. g., fall or winter. One point to which attention should be especially directed is the watering of the animals during the test. If an

Hours After Injection.

\begin{tabular}{|c|c|c|c|c|c|c|c|}
\hline$F$ & 8 & 10 & 12 & 14 & 16 & 18 & 20 \\
\hline $107^{\circ}$ & & & & & & & \\
\hline $106^{\circ}$ & & & & & & & \\
\hline $105^{\circ}$ & & & & & & & \\
\hline $104^{\circ}$ & 3 & & & & & & \\
\hline $103^{\circ}$ & & & & & & & \\
\hline $102^{\circ}$ & & & & & & & \\
\hline $101^{\circ}$ & & & & & & & \\
\hline $100^{\circ}$ & & & & & & & \\
\hline
\end{tabular}

Fig. 15.-Temperature Curves.

1. the temperature curve of a healthy animal after injection with tuberculin; 2 and 3 . the temperature curves of 'tuberculous animals after injection with tuberculin. (After Moore.)

animal drinks large amounts of cold water its temperature is often lowered $2^{\circ}$ to $3^{\circ} \mathrm{F}$. If the depression of temperature should come during the reaction fever, it might lead to a misinterpretation of the results. Water should be given during the test, and no trouble will ensue if given in small quantities.

The increase in temperature in the tuberculous animal is usually a number of degrees. In the case of a positive 
reaction the temperature begins to rise 10-14 hours after injection, reaches a maximum in 12-14 hours and then declines rapidly. The maximum temperature may reach $105^{\circ}$ to $107^{\circ} \mathrm{F}$., e. g., $3^{\circ}$ to $5^{\circ} \mathrm{F}$. above the average normal. An animal is said to have reacted and is looked upon as diseased when the maximum temperature after injection is $2^{\circ}$ or more above the average normal temperature before injection, or is $1.5^{\circ} \mathrm{F}$. above the highest temperature taken before injection. The reaction fever is often so slight that one cannot decide positively from this alone whether the animal is to be adjudged diseased or not. In the interpretation of such cases a full knowledge of the conditions surrounding the test, and a history of the animal is of much value. If many other animals of the herd have reacted, a less rise in the case of one or more animals would be classed as a reaction, when it would not be in case no other animals had shown any signs of a reaction.

Suspicious animals should be retested with a larger dose (3 fold) after a period of 60 days. Animals once tested will not give a proper reaction upon retest if tested within a short time after the first injection. Sufficient time must elapse to permit elimination of the first tuberculin. Animals in the last stages of the disease often do not react. The disease in such animals can usually be diagnosed by a physical examination. During the incubation period of the disease before any diseased tissue has developed, animals do not react to tuberculin.

The purely mechanical part of the test can be carried out by any intelligent farmer capable of reading accurately a clinical thermometer. The interpretation of the test should, however, be made only by an experienced 
person. No farmer should fail to test his herd because a veterinarian is not to be obtained or because of the expense of employing one. The tuberculin can be purchased of reputable firms at a cost of 15 to 25 cents per dose. The instruments need not cost over five dollars. The work can be done during the times when the farm work is least pressing.

The advantage of being able to test one's own animals is very great, since retests can be made on suspicious animals and animals to be brought into the herd, tested. If some one must be employed to make those tests at irregular times, the testing is likely to be neglected and because of this neglect, the farmer may fail to free his herd from the disease or may introduce it by the pur. chase of a cow supposed to be healthy.

Reasons for testing the herd. Every farmer should determine the condition of his herd for its own sake because delay means increased loss through diminished production of diseased animals, through further spread of the disease in the herds, and through death of animals before the normal time. From the standpoint of duty to himself and to society, he should see that his herd is healthy. This can be, done only by the use of the tuberculin test.

Some states have passed laws requiring compulsory testing, and for animals found affected, partial remuneration is given. The methods of disposal of reacting animals depends upon the state of the disease. When the carcass is affected only slightly, it is passed for food under Federal inspection. If the disease shows evidence of being generalized, the carcass is condemned and tanked for fertilizer.

As previously indicated, it is possible to raise healthy 
calves from diseased mothers. With valuable breeding stock, the loss caused by immediate slaughter would be too great. The herd may be separated into the affected or reacting, and the healthy. The two herds should be kept in separate barns and pastures; the calves of the diseased animals should be removed at birth and fed on the milk of healthy animals or on the milk of the diseased animals which has been heated to at least $160^{\circ} \mathrm{F}$. so as to destroy any tubercle organisms it may contain. It has been shown many times in Denmark and in this country that by this method a diseased herd can be put on a healthy basis within a few years and at very slight expense. Any farmer who wishes to employ this system should apply to the state authorities connected with the control of enntagious diseases of animals for more detailed advice. There is no successful practical means at present of protecting cattle against tuberculosis by vaccination. Certain methods have been widely advertised as efficient, but are not a practical success.

Tuberculosis of swine. Hogs acquire the disease very easily by the ingestion of contaminated food, such as skim milk, butter-milk, slime from cream separators, or from cattle in feed lots. The parts of the body most often affected are the glands of the head, neck, and intestines. The liver may show large rounded nodules, yellowish-white in color, or minute nodules in great numbers. The spleen often shows large nodules and the lungs many small ones.

Since the larger number of hogs are sent to market before they are a year old, the disease does not usually make such headway as to cause any visible symptoms. The tuberculin test has been used in the case of hogs, but it is much more difficult to apply than with cattle. 
The temperature of the hog is much more variable than that of the cow. During the test the animal must be kept perfectly quiet, which can be done only by placing it in a narrow crate so that movement is impossible.

Tuberculosis of fowls. The disease in chickens and other barnyard fowl is due to a different variety of the tubercle bacillus than that causing the disease in cattle and man. It has caused great loss in many flocks. The most important symptoms are emaciation, although the appetite is good. The eyes are bright, until shortly before death, although the fowl may be weak and move about but little. The birds are often lame due to the disease in the joints.

Of the internal organs the liver is most affected. At first it shows small, grayish points, later, yellow patches appear.

Differential diagnosis. There are some diseases of cattle and sheep that are often mistaken for tuberculosis, especially those in which nodules are produced in the walls of the intestines by animal parasites. Sheep are affected with an intestinal disease known as "nodular disease" which to the uninitiated might be thought to be tuberculosis, but which is really caused by a parasitic worm which burrows in the wall of the intestine forming a greenish colored nodule about the size of a pea. 


\section{CHAPTER XII. \\ GLANDERS AND TETANUS.}

Glanders is one of the important diseases of the horse. It appears in two forms, the one type affecting the mucous membranes being ealled glanders, while that which affects the lymphatic system of the skin is called farcy. The disease is primarily one affecting horses, mules, and asses, but dogs and cats may acquire it by eating glandered meat. Man may also be affected, generally acquiring the disease from horses. It is an especially fatal trouble in man.

Distribution of the disease. Glanders is found in nearly all parts of the world. Australia is said to be free from it. The congregation and transportation of large numbers of horses, as is necessary in war operations has been instrumental in spreading the disease widely through the world. During and after the civil war its distribution was very rapid in this country due to the sale of horses and mules by the government. In the Mexican war, it was introduced into Mexico by the American cavalry.

The disease is more often found in large stables than on the farm. In lumber camps, on the ranges, and in the cities, it is constantly present. Farmers who buy animals from such places are likely to bring the disease onto the farm. There are certain conditions that predispose the animal to the trouble such as unsanitary surroundings in the stable and overwork.

A horse may be in good flesh and be able to stand work and yet have the disease in a chronic form for 
years. It is through the purchase of such an animal as this that the disease is brought onto the farm, such animals also serving to spread the trouble through the infection of mangers and watering troughs.

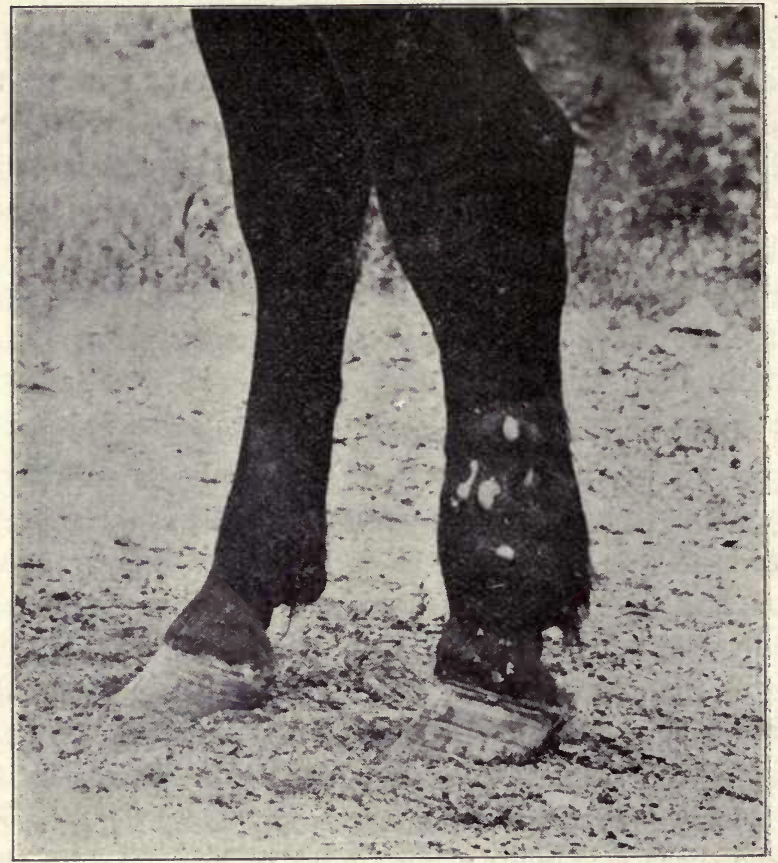

FIG. 16.-GIAANDERS.

Sores formed by the breaking of the farcy buds. Note the swollen condition of the leg. (After Reynolds.)

Symptoms of the disease. The acute form of the disease is rare in the horse but common in the mule and ass. In the chronic form the development is usually slow and insidious. There is generally a-discharge of 
a sticky fluid sometimes streaked with blood from one or both nostrils. The animal may be lame and may cough.

In glanders of the skin (farey) nodules which are ealled farcy buds are found in the skin and in the adjacent tissue. They vary in size from that of a hempseed to that of an egg. These nodules break and form running sores on the surface of the body, the discharge being yellowish and sticky. The nodules usually appear on the legs and on the head. The sores often heal but leave a permanent scar.

Tissues affected by the disease. In chronic glanders the changes in the tissues are found in the air passages, the lungs, lymph glands and skin. Small nodules may form on the upper part of the septum of the nose. The nodules, which are translucent and grayish in color, may break and form ulcers which destroy the surrounding tissue to a greater or less extent, a perforation in the bony nasal partition may even be produced. There are found in the lower air passages and in the lungs nodules resembling very much those of tuberculosis. They are pearl-gray in color, usually have a yellowish spot in the center due to the death of the tissue. The nodules are found both on the surface of the lung and in the lung tissue. Similar nodules are also found in the spleen and less often in the liver and kidneys.

Care should be exercised in the handling of suspected horses as the disease is easily transmitted to man. The symptoms in the human being are much the same as in the horse, sores forming on the hands and in the eyes and nose. Death usually takes place in two to four weeks although the disease may become chronic. Treatment is of little avail. 
Mallein test. Glanders can often be recognized by a physical examination on account of the characteristic sores in the nose. The horse is subject to nasal diseases that may be mistaken for glanders. When the disease can not be diagnosed by the physical examination, recourse may be had to the mallein test which is similar to the tuberculin test.

Mallein is prepared in the same manner as is tuberculin by growing the glanders bacillus in glycerin broth. The manner of applying the test is also similar to the method followed in the tuberculin test. The mallein is injected beneath the skin and a series of temperatures taken both before and after the injection is made. A few hours after the injection of the mallein there appears at the point of inoculation, a hot inflammatory swelling, which in a glandered horse is very painful, and continues to increase in size for twenty-four to thirty-six hours. This persists for several days, gradually disappearing in eight to ten days. With healthy horses a small swelling is produced at the point of inoculation but it disappears in twenty-four hours. At the time the swelling appears the diseased animal is dull, breathes rapidly and has a poor appetite. In healthy horses no such effect is noted. In the affected animal a rise in temperature, from 2 to $2.5^{\circ} \mathrm{F}$., occurs in the course of eight hours, reaching its maximum in ten to fifteen hours. The high temperature persists for twenty-four to forty-eight hours instead of only a few hours as in the tuberculin test. In healthy horses there is no rise in temperature. The test is not quite so reliable as the tuberculin test for some diseased animals do not react to the mallein test. Any animal that reacts to the test is certain to have glanders. 
In most of the states glandered horses are destroyed by the health anthorities whenever they are detected. The farmer should protect his horses against glanders by not allowing them to come in contact with strange horses, especially if there is any reason to believe that the animals may be affected. If an animal is purchased from a sale-stable or from a range, it is well not to bring it in contact with the farm horses, until it is certain that it is not affected with the chronic type of the disease. The use of the public watering trough and public stables is often a means of infecting a healthy animal. A stable in which a diseased horse has been kept should be disinfected. The glanders organism does not form spores, hence is easily killed.

\section{TETANUS.}

Tetanus or lockjaw as it is often called, is a disease that appears most often in the horse and mule. It may however affect any of the domestic animals and also man. Tetanus occurs in all parts of the world, most frequently in the warmer regions.

The organism causing the disease is an anaerobic one, the real home of which is in the soil. The disease is not a directly contagious one, i. e., one animal does not acquire it from another. The infection takes place through a wound, especially one into which dirt is carried. A wound which bleeds freely is less dangerous than one that does not as the organisms are likely to be washed out. A contused lacerated wound is especially dangerous as the opportunity for admission of dirt is increased. Wounds caused by rusty and dirty nails are often a way in which the bacteria are introduced into the body. The disease may follow an operation, such as 
the docking of horses, the castration of colts, and through the infection of the umbilical cord of colts.

Symptoms. The organism grows only at the point of introduction. It produces one of the most powerful poisons known. This is absorbed and is carried to all parts of the body and its action on the nerves causes the characteristic symptoms, of spasms in various muscles. The muscles of the throat and jaw are often paralyzed, giving rise to the common name of the disease, lockjaw. The muscles of the neck may be involved, causing the head to be held in a stiff outstretched manner. Those of the back and tail are also affected.

On post-mortem examination no marked lesions are found. The disease is usually fatal in sheep and in hogs; about 75 per cent of the horses affected die. The duration of the disease in the horse may be but a few days or it may continue for several weeks.

Preventive measures. A preventive and to some extent a curative treatment has been developed in the tetanus antitoxin. This antitoxin is prepared in the same manner as that used for the prevention and cure of diphtheria. A horse is injected with a small amount of the filtrate of a culture of the tetanus organism in broth. This contains the same poison that the organism produces in the body of the animal. A very small dose must be given at first. The horse soon recovers from the effect of the injection and a larger dose is then given. The treatment is continued for some time with larger and larger doses of the poison. Meanwhile the animal is producing a substance in its body to counteract the poison that has been given it. This process of forming the antitoxin does not cease when enough has been made to neutralize the amount of poison given, but an excess 
is made and is found in the blood of the animal. If some of the blood can be carried to an animal that has just begun to show symptoms of tetanus, the antitoxin contained in it will neutralize the poison that is being formed and thus tide over the time until the suffering animal can make its own antitoxin. This transfer of the protecting substance is done by drawing a quantity of blood from the immunized animal, allowing it to clot and collecting the serum which comprises the commercial product. The antitoxin is used in the treatment of both horses and man. In order to protect an animal against the infection that may occur during an operation a small dose is often given before the operation. In vaccination, where a mild form of the specific disease is always produced, the protection lasts for some time. The protection afforded by antitoxin endures for only a short time.

A large proportion of the disease in human beings is the result of wounds produced by Fourth of July accidents. The filling in many forms of fire works is earth. This may contain tetanus bacilli which will be blown into the skin by a premature explosion of a fire cracker or other form of fire works. 


\section{CHAPTER XIII.}

\section{RABIES.}

Rabies, or hydrophobia, as it is frequently called, is a disease especially affecting dogs. Practically all of the domestic animals and many wild animals may, however, contract the disease. Man is also susceptible. While the disease is especially important on account of its communicability to man, it is becoming of much economic importance to the farmer through the loss of stock infected by the bites of rabid dogs

So far as is known the disease is transmitted from one animal to another or from animals to man only through the bite of a rabid animal. The tendency of the dog to bite is the explanation for the great prevalence of the disease in this animal. The organism causing the disease has never been discovered. Certain structures have been. found in parts of the body that are supposed to be the real cause, although the relation has never been thoroughly established.

Distribution. The disease is found in nearly all parts of the world. Australia is said to be free from it. This freedom is due to the rigid enforcement of quarantine laws in regard to the importation of dogs. England through strict regulations concerning the muzzling of dogs and through her quarantine laws has practically succeeded in stamping out the disease. In our own country rabies is found in every state. In some sections 
it is very prevalent while in others it is rare. It is undoubtedly on the increase in many sections. This is due to the lack of regulations in regard to the muzzling of dogs. Many people believe that the muzzling is an inhumane practice, while still others assert that rabies is a myth and has no existence except in the minds of the doctors. So long as such ideas are held, rabies will continue to exist.

There is probably no other disease with which there is connected so many popular fallacies as with rabies. It is currently believed that it occurs only during that part of the summer known as "dog days." In reality the disease is as prevalent in winter as in summer and if it is desirable to muzzle dogs in July and in August, it is also desirable to muzzle them at all times.

Period of incubation. The period of incubation of rabies is about forty days in man, in the horse from twenty-eight to fifty-six days, in the dog from twentyone to forty days. The period of incubation, however, may vary widely from these averages as it will depend on the location and severity of the bite. The part of the body in which the organism seems to grow is the nervous system. The symptoms of the disease are not apparent until the brain is affected. The time required for the organism to reach the brain depends on the distance of the bite from the brain, thus the symptoms appear more quickly when the bite is on the face than when it is on the limbs. The length of the period of incubation is also dependent on the severity of the bite. Where a slight wound is inflicted, the symptoms will not as a rule follow so soon as if several wounds had been made.

Symptoms. Two forms of the disease are known, the dumb, and the furious type, so called on account of the 
nature of the symptoms noted. In the rabbit the dumb type is most usual; in the dog it is very rare. The symptoms of rabies appear slowly. With the furious type of the disease, the animal is usually more nervous than normal and more affectionate, or it may be dull and try to avoid people. The nervousness increases until the animal is unable to rest. It may become delirious and snap at the air. The itching of the tissue at the point of inoculation causes the dog to lick the wound or even to bite itself. The nervousness may be so great that the dog leaves home, and starts on a wandering trip which may last for several days, usually returning home in an exhausted condition. During this absence from home is the time of greatest danger, for the dog then comes in contact with other animals. The rabid dog does not go out of its way to bite, as is frequently stated, but any object or other animal that is in its way is very likely to be snapped at. The animal that is most usually bitten is another $\operatorname{dog}$. In this way the disease is spread, as on such a trip the mad dog may infect a large number of dogs.

The animal may die while away from home. More often it reaches home in a pitiable condition, and often the owner may be bitten in seeking to relieve the animal. The greatest care should be exercised in handling any dog suspected of rabies. As the disease progresses, certain parts of the body become paralyzed, the museles of the throat generally being the first to be affected. This has led to another popular fallacy, namely that a rabid animal has a great fear of water, often going into fits at the sight of water. This fallacy has given to the disease the name "hydrophobia," meaning fear of water. The animal is unable to swallow, and in making an attempt 
to do so is often thrown into convulsions. The animal will take water as long as it is able to swallow anything. The paralysis gradually extends and death usually takes place in four or five days after the first symptoms are noted.

In the dumb type the nervousness is not present, the first symptom is usually paralysis of the muscles of the throat. This often leads the owner to think the dog is choking and an effort may be made to remove the suspected object by inserting the hand into the mouth. This is a very dangerous thing to do for the saliva is infectious and if the hand should be scratched in the operation there is danger that rabies may develop. Even the licking of the hand by a rabid animal may serve to infect a person if there is any sore or abrasion of the skin. The extent of the danger from bites depends to a large degree upon the location of the bite. If the teeth of the dog pass through the clothing, the saliva, which carries the virus, will, generally, be wiped off. The disease will be far less likely to follow than if the bite is on an unprotected part as the face or hands. In like manner a long-haired $d o g$ is more protected than a short-haired one. As previously stated the danger also depends upon the severity of the bites. People bitten by rabid wolves more often develop the disease than those bitten by dogs because the bites are likely to be more extensive. Another fallacy connected with rabies is that if persons or animals are bitten by any dog, they are likely to become rabid should the dog contract the disease at any future time. There is, of course, absolutely no foundation for this impression, for the disease is transmitted only by an animal that is diseased at the time the wound is inflicted. 
The body of a dog that has died of rabies shows no: marked changes on post-mortem examination. The stomach is likely to contain foreign objects, such as grass, sticks, etc.

Treatment of rabies. If the disease develops until symptoms are apparent, nothing can be done and death is certain to follow. In human beings the death is one of the most horrible than can be imagined. However, if treatment is begun early enough the disease can be prevented. The basis of the treatment is exactly the same as in the cases of anthrax and black leg. A weakened form of the virus is used. If rabbits are inoculated with a portion of the spinal cord or brain of a rabid animal, they will usually die from the disease in fifteen to twenty days. If repeated inoculations are made from one animal to another, the virulence of the causal organism increases until the rabbits will die in six or seven days. The virulence can not be farther increased and the virus is said to have a fixed strength. The spinal cord of a rabbit that has died after inoculation with such a fixed virus is removed and placed in a dry atmosphere, the resulting desiccation weakens the organism gradually. A person applying for treatment is given a sub-cutaneous iroculation with a suspension in water of a cord that has been dried for fourteen days; on the following day the inoculation is made with a cord that has been dried for a shorter period of time. Within a week or ten days the inoculation is made with a cord that has just been removed from the animal, and which, of course, contains the unweakened virus. The treatment, which was discovered by the French bacteriologist, Pasteur, has resulted in the saving of hundred of lives and has robbed the disease of many of its terrors. The treatment is em- 
ployed only with human beings, although animals could be treated but the expense is too great.

It is noteworthy that the protective treatment can be applied in the case of rabies several days after the bite is inflicted, an unusual condition with reference to immunization. On account of the time and expense connected with the preventive treatment, it is desirable to know with certainty that the suspected animal really has rabies. This can be determined with eertainty only by keeping the dog that inflicted the bite under observation. If the animal is rabid, a definite diagonsis can be made from the symptoms, and death is certain to follow. If the dog has bitten persons, it is especially desirable that it should not be killed for the delay in determining whether the animal was actually rabid or not may be sufficient to allow the disease to make such headway that treatment will be of no value in preventing the disease. Until recently the diagnosis was made by the inoculation of a portion of the spinal cord into rabbits. A more rapid method is now employed, a definite portion of the brain is examined microscopically and within twenty-four hours the diagnosis can be made, while with the old mothod at least two weeks were required.

A very unsatisfactory condition in all methods of diagnosis in the laboratory exists. If the rabbits inoculated succumb to rabies or if the peculiar bodies characteristic of the disease are found in the brain of the suspected animal, it is eertain that rabies is present. If the bodies are not found, it is not certain that the animal was free from the disease. Again, the rabbits inoculated may not die from the disease for a much longer period than the average, so late, indeed, that preventive treatment may be of no value, if it is not begun until the diagnosis is 
made by means of animal inoculation. These things emphasize the importance of not killing the suspected animal, but to secure it, and watch the progress of the disease. If rabies is present the animal is certain to die with well marked symptoms which can not be mistaken. If the $d o g$ is suffering from various other troubles that cause it to be nervous, or if it has inflicted the bite through provocation, an entirely different history will result. Every effort should be made to secure the dog that has bitten other dogs, animals, or persons. If the suspected dog has been killed, the head should be removed and sent to a laboratory for examination; most of the laboratories connected with the state boards of health are equipped for such work. Care should be taken not to injure the brain else diagnosis may be impossible.

The wounds made by a suspected animal should be cauterized immediately to destroy the virus possibly present. This can be done by the use of strong carbolic or nitric acid or, if neither of these are available, by the use of a hot iron. Only about sixteen per cent of people bitten by rabid animals develop rabies and this is greatly reduced when the wounds are properly treated.

The preventive treatment is given in Pasteur Institutes which have been established in the various cities. Some of the states have such institutes in connection with the laboratories of the boards of health. Recently farther improvement has been developed so that the vaccine can be sent by mail to the resident physician, who administers it. In this way a person can take the treatment at home and at much less expense than formerly.

Rabies in other animals. Next to dogs, cattle seem to be most frequently affected, probably because rabid dogs have more opportunity to bite them than any other 
domestic animal except other dogs. Cattle are most frequently bitten on the hind legs, hips and lower jaw. About twenty-five to thirty per cent of those bitten develop the disease. The symptoms are very similar to those described in the dog. The furious type is more common than the dumb. The first symptoms are loss of appetite, of rumination and of milk secretion. Increased nervousness is shown by the bellowing, pawing, and a tendency to attack other animals. On account of the increased amount of saliva, there is a constant frothing at the mouth. The animal becomes stiff and unsteady in its gait. The temperature is not above normal. Death: results from paralysis.

Quite similar symptoms may be noted in other diseases in which the brain is affected as for example in lock jaw, anthrax, and spinal meningitis.

Horses, sheep and hogs are often bitten by rabid dogs. The symptoms are usually those of the furious type of the disease. A rabid horse or hog may bite other animals. or man and cause the spread of the disease. 


\section{CHAPTER XIV.}

\section{ACTINOMYCOSIS, GARGET, COWPOX, AND CON- TAGIOUS ABORTION.}

Actinomycosis or lumpy jaw as it is commonly called, is a disease of cattle although horses, sheep, hogs, and dogs may be affected. Man is also subject to the disease. The cause of the disease is not one of the bacteria but an organism much like a mold. The disease is not a highly important one as only about one out of. sixteen hundred animals are affected with it. Tuberculosis is at least fifty times as prevalent as is actinomycosis and yet in many places the latter disease has made more of an impression on the popular mind than has tuberculosis. The reason is that the changes which tuberculosis produces are hidden, while those of actinomycosis are usually evident on the surface of the body in the form of a lump on the jaw. Animals rarely die of the disease.

Actinomycosis is not a contagious disease since one animal does not acquire the disease from another. The organism that causes the trouble is supposed to grow on barley and other grains. It enters the body through a wound in the mouth, through a hollow tooth or it may be inhaled.

Symptoms. The first symptom is a slight swelling in the region of the head or throat. The swelling gradually increases in size and is hard and dense. It may break and discharge a thick yellow pus. The opening may heal temporarily only to break later and discharge again. 
The discharge may be on the outside or into the mouth or throat. The sore at the point of discharge may become very large and have the appearance of a head of cauliflower. The growth of the tumor may continue for years, death being caused because of its interference with breathing or swallowing. The tongue is sometimes involved, in which case the disease is often given the name

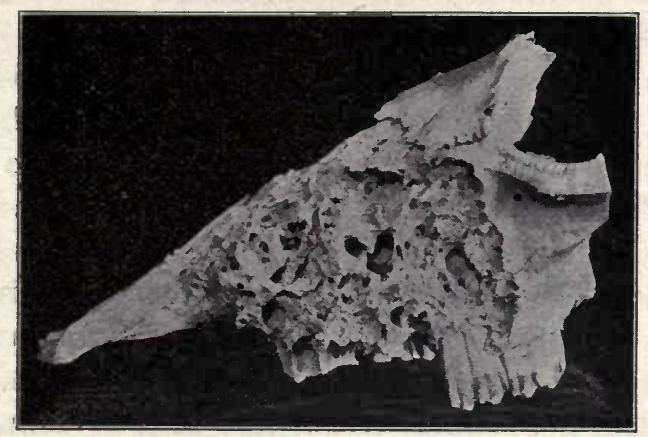

Fig. 17.-Actinomycosis.

The spongy condition of the jaw bone was produced by the growth of the fungus.

of "wooden tongue." The organism may invade the bony part of the jaw, causing the bone to become spongy and enlarged, while the teeth may fall out.

Lesions. The lesions of actinomycosis may occur in various other parts of the body than about the head. In the lungs nodules are often formed that are very similar to the nodules found in tuberculosis of the lungs. They vary in size from mere specks to that of a pea. Still other organs, as the spleen, liver, and udder may contain the nodules produced by the growth of the organism. The pus discharged from the actinomycotic nodules is 
yellowish and contains minute yellow granules, often called sulphur grains. These are masses of the causal organism.

Treatment. The disease is one that yields quite readily to treatment. The most successful remedy is potassium iodide which is given in water as a drench. The dose is from 1.5 to 2.5 drams per day. The treatment can not be maintained continuously for a long time as the drug affects the animal unfavorably, causing the eyes to run, the skin to become dry and rough, and a loss of appetite. When these troubles manifest themselves the medicine must be stopped for a few days and then begun again. Three to six weeks are required to effect a cure. All animals do not respond to this treatment. Iodine should never be given to milch cows as it is given off in the milk. It also decreases the flow of milk or may stop it entirely. It is also likely to cause abortion.

Man does not acquire the disease directly from cattle. but is infected in the same manner as are cattle through wounds in the mouth. The meat of animals that have the disease in a localized form is fit for human food and is passed by the inspectors in the slaughter-houses.

\section{GARGET.}

Inflammation of the udder is known by various names as garget, mastitis or mammitis. The trouble is characterized by the production of a fever and a swelling of the gland with more or less change in the nature of the milk. Catching cold in the udder or an injury are often responsible for the trouble. Animals differ widely in their susceptibility to udder troubles. With some, lying on a cold concrete floor is sufficient to cause trouble. An injury serves to introduce some of the bacteria of the skin 
or of the milk ducts into the udder tissue where they cause inflammation. Such physiological troubles are usually confined to a single animal, and the swelling and fever are generally temporary. In well developed cases the milk is likely to contain flakes of slimy clotted material. If the inflammation persists, the milk secretion may cease altogether and only a yellowish liquid be obtained. If the attack is of short duration, no permanent harm is likely to result, the normal flow of the diseased quarter may be restored during the same lactation period or at the beginning of the next. A prolonged attack is likely to cause a loss of the quarters involved.

A much more serious type of garget is that known as infectious or contagious garget, which is caused by certain bacteria which are able to grow in the udder and cause serious trouble. This form is much more important than that caused by cold or wounds as it is very likely to spread from one animal to another. The milker is usually the cause of the spread of the trouble in the herd. An animal that has garget in any form should be milked last or the hands should be washed in a disinfectant such as can easily be made by the use of the corrosive sublimate tablets that can be obtained at any drug store. It is also advisable to remove the animal from the stable. Through carelessness a large part of the herd may become infected.

The milk from animals having inflammation of the udder, no matter how slight it may be, should not be mixed with that from healthy animals. It should be thrown away. 
Small pox in man finds its counterpart in diseases of similar nature in the cow, horse, and sheep. There is apparently some relation existing between human small pox and cow pox, as inoculations from man to the cow and from cow to man can be made. The disease in sheep is limited to sheep alone, not even being transmitted to goats.

The lesions of cow pox appear on the udder and teats. The first symptom is a tenderness of the skin, followed by the appearance of small reddish spots, which develop into vesicles or blisters filled with a clear liquid. Later the contents become more like pus. The pustules become darker in color and drier until nothing remains but a dry scab that drops off. The duration of the disease is about twenty days.

It is not a serious disease as far as the herd is concerned. With milch cows it may cause a great deal of inconvenience in milking. The vesicles are broken by the hand of the milker, thus producing large sores on the teats which heal slowly and which make milking very difficult. An effort should be made to limit the spread of the trouble in the herd by milking the affected cows last, since one of the agents of distribution of the disease in the herd is the millzer whose hands are contaminated from the ruptured vesicles. Nothing can be done in a curative way, but the use of carbolized vaseline on the teats may serve to make the milking less difficult and aid in healing the sores.

The milker may become infected from the cow by getting some of the contents of the vesicles into a wound or crack on the hand. The trouble in man is local and not at all serious unless the sores become infected with pus- 
forming bacteria. An attack of cow pox protects the individual against small pox. In fact the beginning of modern vaccination against small pox was due to an observation made by Jenner that people that became infected with cow pox did not acquire small pox. Vaccine, which is used as a preventive against small pox, is made by inoculating calves with the virus of cow pox. To make the vaccine the scabs, that form, are removed and ground with glycerine. All the processes are carried out with the greatest care in order to avoid the contamination of the vaccine with organisms that might be injurious to the persons vaccinated.

\section{CONTAGIOUS ABORTION.}

The causes of abortion in eattle may be divided into three classes: (1) abortion caused by mechanical injury or as the result of some other disease, (2) abortion due to the presence of large amounts of smut in the feed, (3) abortion due to the infection of the animal with a specific organism. The first two classes are of interest to us only as they are to be differentiated from the true contagious abortion. The eases of abortion belonging in the first class are sporadic and are caused by some injury, such as slipping, falling, being hooked, jammed or kicked. The cases occur singly and no connection between the cases can be traced.

Ergot or smut of corn and other plants when ingested has such an effect on the uterus as to cause the expulsion of the fetus. If the cause is of this nature a large number of cases of abortion are likely to occur within a short time since all the cattle are under the same conditions. With a change of feed the trouble disappears. Some 
plants to which cattle may have access in the pasture have a like effect on the pregnant animal.

Contagious abortion or that caused by micro-organisms is more prevalent and more important, since one infected animal introduced into the herd may serve to infect the entire herd.

Cause. The organism responsible for the trouble is not known with certainty. The disease is undoubtedly most often brought into the herd through the purchase of an infected animal. Once introduced it spreads from one animal to another in various ways. The first case in the herd is not likely to attract attention and hence opportunity is offered for further spread. Much would be gained if every case of abortion in the herd were treated as though it were contagious. The disease usually disappears from a herd in two or three years, in case no new animals are brought into the herd or young animals do not serve to perpetuate the disease. This has been supposed to indicate that an animal becomes immune after two or three consecutive abortions. The abortion usually occurs between the fifth and eighth months of the period of gestation.

Symptoms. Shortly before the time for the fetus to be expelled, symptoms are shown in varying degree by different animals. The vulva and surrounding tissue is swollen and a yellowish discharge is noted. The udder increases in size. Within two to three days delivery occurs, which is usually accomplished without trouble. If the abortion occurs during the eighth month of pregnancy, the milk flow will usually be quite normal, at earlier periods the animal gives milk but a short time. 
Infection of the animal. There are many ways in which the causal organisms may be carried from the infected animal to a healthy one, as by direct contact, soiled bedding, the attendants, etc. A less direct way is by the bull that has served infected animals and later has been used with healthy cows. The bull is one of the means of introducing the disease into the herd, either through purchase or by the use of the bull of the herd on infected cows or by patronizing bulls kept for public service.

Prevention. Attention should be directed to the condition of the herd from which each animal is purchased. If it is not certain that the herd is free from the disease, it may be well to keep the purchased animals apart from the herd until after calving at full time has occurred. In order to prevent the spread of the disease in the herd attention must be directed toward the destruction of all material that may contain the organisms. To accomplish this, the fetus and after-birth should be destroyed, preferably by burning. The aborting animal should be removed from the herd, the stable disinfected and all cows that may have been exposed also disinfected. The animal should be given vaginal douches with some disinfecting solution such as one ounce of tincture of iodine in one ounce of glycerine, the mixture being added to one gallon of warm water. The external genitals, hind quarters, and tail should be washed with a one to one thousand solution of corrosive sublimate. The douches and external treatment should be repeated several times and the animal should not be returned to the herd as long as there is any vaginal discharge.

All pregnant cows of the herd should be treated by washing the external genital parts with corrosive subli- 
mate and the vagina should be cleansed with a suitable antiseptic solution. The bull may be treated by washing the external parts of the sheath and the abdomen with soap and water and then with a one to one thousand solution of corrosive sublimate. The sheath may be injected with a one per cent solution of carbolic acid.

The disinfection of the stable should be done as described in a subsequent chapter. It rests largely with the owner as to whether the disease persists or not. The measures necessary to prevent the spread of the trouble in the herd may be burdensome and are very likely to be neglected. It is very certain that the various methods of treatment widely advertised rely for their effectiveness upon such means as the farmer can apply for himself. 


\section{CHAPTER XV.}

\section{DISEASES OF HOGS.}

The hog may be affected by a number of the diseases that have already been treated, such as tuberculosis. By far the most important disease that especially affects the hog is hog cholera. It is probable that there are two and possibly three diseases, caused by different kinds of organisms to which this term is usually applied. The veterinarians have called one of these diseases hog cholera, another swine plague, and within recent years, it has been found that there is still a third kind of organism which causes trouble in the hog. These diseases may be discussed together since methods of prevention are identical.

The knowledge of no other important group of diseases of the domestic animals is in such an unsatisfactory condition as that concerning the diseases of the hog. This is true both with reference to the causal organisms, and to methods of prevention by means of vaccine or serums. Until very recently no progress had been made in methods of fighting the diseases of the hog for twenty years.

Distribution. Hog cholera is supposed to have been imported to this country in the hogs introduced from Europe. The first outbreak of which record is had was in Ohio in 1833. Since that time. it has spread to every state. In the great corn growing states it causes greater annual losses than any other disease of the domestic ani- 
mals. It is found in England, Germany, and other European countries.

Symptoms. The hog when ill usually shows much the same symptoms, whatever the trouble may be. The disease develops from seven to fourteen days after. infection occurs. When the disease appears in a herd, some of the animals are certain to die after a short illness of a few hours, or at longest a few days, of acute cholera. Others show signs of illness for a much longer period and some recover. The animal acts dumpish, and tries to hide. The appetite usually is very good. The skin of the ears, nose, abdomen, and inside of the thighs is reddened. With chronic cases weakness of the limbs, especially the hind legs, develops and the animal moves with difficulty.

Post-mortem examinations. The disease often cannot be diagnosed with certainty from the symptoms, but an examination of the carcass is necessary. In the acute type one of the most common and striking changes is in the spleen. This organ is often much enlarged, soft and very full of blood. Hemorrhages are found in various parts of the body, especially on the lining of the abdomen and chest, and on the inner wall of the intestine. The intestinal contents may be surrounded by a blood clot. In the chronic form the most characteristic lesions are found in the large intestines in the form of ulcers on the inner wall. The ulcers may be as large as a hickory nut and because of the rounded form are called "button ulcers." The death of the tissue near the ulcer may be so extensive as to cause a perforation of the wall of the intestine, thus giving an opportunity for the intestinal contents to escape into the abdominal cavity. Such a 
condition produces inflammation (peritonitis), causing death. In this type the spleen is not usually enlarged and the lungs are normal.

Hogs are subject to intestinal troubles that are often mistaken for cholera, but may be differentiated from it through the fact that they do not spread to other herds. The trouble may be produced by unsuitable food, such as house refuse containing much soap. Often the mortality with such troubles is high, and the rapid death of the



Fig. 18. - Hog Cholera.

Button ulcers on the inner wall of the intestine in a case of chronic hog cholera. (After Reynolds.)

animals causes the farmer to think a contagious disease is present. The term "swill-barrel" cholera is often used for such outbreaks.

Prevention. As there is no cure for the disease, the owner must devote his efforts to prevention. The disease may be brought onto a farm in a number of ways, most frequently, through the purchase of animals. As previously stated animals recover from the disease. Such animals may harbor the disease-producing bacteria in their bodies and disseminate them subsequent to apparent recovery As soon as such animals are brought 
into a healthy herd, an outbreak develops, since many of the animals of the herd will be very susceptible to the disease. The bacteria are given off from the body of the affected hog in the manure and are taken into the body of the healthy animal with the food.

No animal should be purchased from a herd in which hog cholera has been present during the previous year. Animals purchased should be kept in quarantine when first brought onto the farm, and then placed with a small part of the herd. If these exposed animals all remain healthy after two to three weeks, it is safe to place the purchased animals with the herd. The method of keeping hogs in separate houses instead of in a large hog house has much to recommend it, for if cholera breaks out in one part of the herd, it can often be kept from spreading to the other sections of the herd.

Hogs frequently acquire the disease from infected cars, shipping crates, etc. The disease may be spread from herd to herd by infected objects, such as farm tools carried from one farm to another. The farmer himself may inadvertantly serve to disseminate contagion, by visiting his neighbor to inspect an infected herd and bringing home the virus of the disease in the slight amount of manure that may eling to his shoes. Birds and rats may also carry the disease. The exhibition of hogs at fairs is often a means of bringing the animals in contact with the disease.

When hog cholera is present in the neighborhood, the greatest care must be taken to prevent its introduction onto the farm. At the first signs of sickness in the herd, all animals that appear healthy should be removed to another field. All carcasses of hogs that have died of cholera should be burned or buried very deeply, first cov- 
ering the body with quick-lime. Carcasses should never be thrown intó streams or left uncovered to decompose. The pens and yards should be thoroughly cleaned and well sprinkled with quick lime. The litter and manure should be burned. After a lapse of several months the pens should be whitewashed. The organism does not form spores, hence is easily killed.

Vaccination and serum treatment. For many years efforts have been made to discover a vaccine that would protect from hog cholera as the black leg vaceine protects against that disease, but the efforts have met with little success. Recently methods have been devised that seem to promise success in preventing the spread of the disease. A hog that has recovered from an attack of hog cholera is immune to further attacks. If this immune animal is inoculated with the blood of animal that has the disease, the amount of protective substance in the blood of the immune animal will be greatly increased, so much so, that if some of its blood serum is transferred to a second animal, it will be protected against a natural attack of the disease for about a month. This method of prevention is similar to the use of antitoxin in lockjaw. If it is desired to make the protection more permanent, a small amount of blood from a diseased hog is injected into the animal at the same time the serum is administered. In this case the protection lasts for a long time, possibly during the life of the animal. Many difficulties are encountered in the use of the serum treatment in a practical way. It is to be hoped that these may be overcome and the method made a real success. The treatment can only be administered by a trained veterinarian, especially is this true when the virulent blood is used together with the serum. 
Swine plague. It is believed that swine plague is a distinct disease from hog cholera, produced by a different organism. The diseases often occur together, each producing its peculiar lesions in the body of the animal. From the standpoint of prevention, all that has been said concerning hog cholera applies to swine plague. It is not certain whether the method of vaccination against hog cholera is of any value in cases of swine plague. It is claimed by some that there is but one disease caused by an organism so small that it cannot be seen with the most powerful microscope, and that the organisms supposed to be the cause of hog cholera and swine plague are of secondary importance. Others claim that there are three distinct diseases.

The disease of swine plague is primarily one of the lungs and it is supposed that the infection occurs through the lungs. The lungs may show consolidated areas, in which the organ has the appearance of solid flesh or liver, instead of the spongy normal texture, and the air passages may be filled with an exudate. 


\section{CHAPTER XVI.}

\section{DISEASES OF FOWLS.}

There are a number of diseases of chickens and other fowls caused by bacteria. These diseases inflict a heavy tax on the poultry raiser and the general farmer. Present knowledge concerning these various diseases is far from complete; in some cases not sufficient to control the disease with much hope for success.

Chicken cholera. Chickens like swine are subject to dietary disorders which may often simulate a true contagious disease in the rapidity of its appearance and in the high mortality. It is certain that most of the outbreaks reported as chicken cholera are not caused by the specific organism of chicken cholera.

Symptoms. The yellow color of the urates is the earliest symptom; these in healthy birds are pure white. Diarrhea is present, the manure varies, sometimes being a pasty, greenish mass, a brownish-red slimy material or a thick clear liquid. The sick bird leaves the flock, becomes weak and drowsy, acts dumpish, and the feathers. are roughened. Intense thirst is usually noticed, the appetite is poor and the crop distended with food. The diseased fowls rapidly become poor. The disease makes: rapid headway in the flock since the period of incubation is short, (one to three days.) Most of the affected birds. die in a short time of an acute form of the disease; others may have the chronic form, but recovery is rare. 
Post-mortem examination. The liver is usually very much enlarged and softened; the intestinal organs are congested, but the changes are not such as make it easy to diagnose the disease.

Manner of infection. The bacteria are found in the blood at the time of death. If any part of the carcass is consumed by well birds, they are certain to become infected. The only known manner of infection is by the food or water. The material that drops from the beak of the sick fowl may serve to contaminate the drinking water. The extensive lesions of the intestines allow blood to be mixed with the manure, and the contamination of the food with this material is a cause of rapid spread of the trouble.

The disease may begin in a flock by the introduction of a bird ill with the chronic type of the disease. Doves and wild birds are also supposed to be agents concerned in the spread of cholera. The improper disposal of dead birds, as by throwing them into a stream may cause infection of flocks at a distance.

Prevention. Nothing can be done for the already infected bird. All efforts must be concentrated in preventing the spread of the trouble, by the prompt disposal of all dead birds, the killing of any that show signs of illness, thorough disinfection of the roosting houses, and the feeding and watering troughs. If possible the flock should be moved onto fresh, uncontaminated grounds. The germ is easily killed by drying, sunlight, and disinfectants. It has been shown by experiment that it is safe to bring new stock onto land after a period of two weeks, if care has been taken in the disinfection of the house and other contaminated objects. 


\section{Diseases of F'ouls.}

Fowl typhoid. This disease is thought to be more widely spread than chicken cholera. The disease is less rapid in its progress in the individual bird, than is cholera. It is often mistaken for this disease for there are no marked differences in the symptoms. The diarrhea so characteristic of cholera is usually absent and the intestines are pale instead of deep red, and the contents of normal consistency, while in cholera the intestinal contents are liquid and blood stained. It is not especially important that a correct diagnosis be made as to which of these diseases is present in the flock, since identical methods of prevention should be employed with either.

Roup, or diphtheria in fowls. The disease of diphtheria of fowls is not caused by the same organism causing diphtheria in human beings. It is considered to be the most important disease of chickens in this country. It is claimed that it affects turkeys, ducks, pigeons, and pheasants, as well as chickens. The cause of roup has not been discovered with certainty.

The first symptom to be noted is a discharge of a watery liquid from the nostrils, and often from the eyes, and the bird becomes dumpish. The breathing is often ncisy, due to the obstruction of the air passages with the discharge; the fowl may be able to breathe only by opening its mouth. Sneezing is frequent. Diarrhea appears later, the evacuations being greenish or yellowish. The eyes may be covered with the dried discharge, or they may be forced from their sockets, due to the accumulation of cheesy matter in the sockets. There are to be found in the mouth and throat, patches of grayish-yellow exudations, called false membranes which are similar to the membranes formed in the case of diphtheria in human beings. The elosing of the throat by the membrane 
causes death by suffocation. The accumulation of the exudate in the cavities of the head often causes a swelling, hence the common name for the disease "swell-head."

The disease is to be differentiated from simple catarrh, which closely resembles the "cold in the head" of man. Simple eatarrh is caused by improper ventilation of houses, dampness, cold winds, and exposure. Roup is. often supposed to be produced by similar conditions. It has been shown experimentally that it is not possible to produce it by such means, although they undoubtedly favor its spread when once it is started in the flock.

Prevention and treatment. The disease is most often introduced into the flock by the purchase of a bird having the disease in such a mild form that no symptoms arenoticeable. Fowls that come from flocks in which the disease is present or has been recently present should not. be placed with other flocks. Any bird showing an exudate from the nostrils or eyes should be removed from: the flock at once. Care should be taken to avoid distribution of infection from diseased flocks to healthy ones, by means of the dirt on boots, farm implements, etc.

The dipping of the heads of the affected birds in a ' 2 per cent solution of potassium permanganate is said to be an aid in the treatment of the disease. 


\section{CHAPTER XVII.}

\section{MISCELLANEOUS DISEASES.}

Diseases caused by wound infection. There are many diseases of domestic animals that are produced by organisms that enter the body through wounds. One of the most important is that known as white scours or diarrhea in calves. It affects calves a few hours to a few days old, eausing death in 70 to 90 per cent of cases. The discharges from the bowels are light colored, profuse and very offensive in odor. The animals lose flesh rapidly and have the appearance of suffering from severe sickness. The duration of the disease is from three to six days. It rarely attacks calves after they are from two to three days old. Once established in a stable, the disease may persist for years unless stringent means are taken to rid the stable of the infection.

Treatment is of no value. Attention must be directed to prevention. It is believed that the organisms enter the body through the umbilical cord and that, if means are taken to prevent such infection, no trouble will result. In order to accomplish this, the animal about to calve should be placed in a clean stall with an abundance of bedding. The tail, hips, and external genital parts should be sponged with a solution of carbolic acid or corrosive sublimate (1-2500). The cord of the young animal should be cleaned carefully and a mixture of one ounce of tincture of iodine in two ounces of glycerine applied. The treatment is to be repeated daily for three 
or four days. The stable should be disinfected and all infectious matter destroyed.

The infection of the umbilical cord in colts and lambs may serve to produce a general infection of the body with harmful organisms. Infection of the spermatic cord in the castration of colts often produces serious troubles. All minor surgical operations on animals should be carried out with regard to cleanliness of the part to be operated upon, the hands of the operator and his instruments.

It is also generally believed that two very common troubles in the horse, fistulous withers and poll evil, are due to wound infection with pus-forming bacteria. The wound need not be a noticeable one, an irritation of the skin due to ill fitting harness, saddles or blows being sufficient to introduce the organisms found in the skin into the deeper tissues where growth is possible.

Foot-rot in sheep is due, at least in many cases, to the infection of the tissues of the foot with pus-producing bacteria. The disease may pass from one animal to another until a large part of the flock is infected. The local application of disinfectants is the treatment em. ployed.

Foot and mouth disease. Foot and mouth disease is one of the important diseases of Europe. It affects cattle, swine, and also man. From Europe it has been exported to other countries, especially to America. In 1870 it was present in New England and New York. In 1884 an outbreak occurred at Portland, Maine. In 1902 the disease was introduced into Massachusetts, New Hampshire, Vermont, Rhode Island; in 1908 in New York, Pennsylvania and Michigan. By prompt action, the disease was stamped out at each of these outbreaks. 
The disease is marked by the appearance of blisters on the lips, gums, tongue, and inside of the cheeks. One or more feet may be diseased. Blisters appear on the coronet and between the hoofs and often on the teats. Recovery is usual except in very young animals.

One important phase of the disease is that the organisms, whose nature is unknown, are often present in the milk. People using such milk in a raw form are thereby infected. The disease in man presents much the same symptoms as in the cow. Hogs also acquire the disease from milk.

Distemper in horses. Influenza, or as it is frequently called distemper or pink eye, is a contagious disease, the cause of which is unknown. Infection takes place from horse to horse. The virus can be carried by infected human beings, litter and harness, etc. The period of incubation is two to seven days. The disease appears quickly. It is marked by a loss of appetite, a fever of $3^{\circ}$ to $4^{\circ} \mathrm{F}$. above normal, persisting for three to six days. The animal is dull; at first it is constipated; the feces are in hard balls, covered with slimy matter, later diarrhea is present. The eyes are inflamed. The disease lasts six to ten days. From 2 to 4 per cent of the afflicted animals die.

Distemper in dogs. Distemper is the most important disease of dogs. The cause is not known; the period of incubation is four to six days. The eyes are inflamed, the exudate dries and often causes the lids to adhere to each other. Constipation at first, is followed by diarrhea in which the feces have an offensive odor, and are often slimy and frothy. There is a nasal discharge. It 
may affect the brain and the animal is then often thought to be rabid. The mortality ranges from 50 to 60 per cent. The only means of prevention of the spread of the disease is by isolation of all diseased animals, and the use of disinfectants. 


\section{CHAPTER XVIII.}

\section{DISINFECTION.}

It has been seen that the disease-producing bacteria pass from the bodies of living and dead animals in a number of ways, as in the material coughed up from the lungs, as in tuberculosis; in the manure, as in hog cholera; in the milk, as in tubereulosis; in the contents of abscesses and carbuncles, as in anthrax, black leg, and pyogenic troubles, and in the discharges from the nostrils, as in glanders. The bacteria thrown off from the bodies of the diseased animal contaminate the stables, yards, and fields, and from these contaminated places and objects often enter the bodies of healthy animals thus serving to perpetuate the disease in the herd.

If the farmer is to stop the spread of transmissible disease, he must destroy in some effective way the bacteria that have been thrown off from the bodies of diseased animals. In short he must disinfect the barns and stables, and as far as is possible the yards and fields.

In the destruction of the pathogenic bacteria consideration must first be given to the resistance of the organism it is desired to destroy. For this purpose the various disease-producing bacteria may be divided into two classes; those that-produce spores and those that do not form these resistent bodies. The former class of bacteria are very difficult to kill, the latter are easily destroyed. Fortunately, but two of the important diseases of animals are produced by spore-bearing bacteria. 
black leg and anthrax. The most important and most common of the diseases affecting the domestic animals are caused by bacteria that do not form spores.

Disinfectants. Disinfecting agents may be divided into two classes, physical and chemical. The effect of the most important physical disinfectant, sunlight, has been discussed in a previous chapter. Sunlight rapidly destroys all vegetating bacteria and their spores as well, if it falls directly upon them. If, however, they are covered with a layer of dirt or dust even though it be very thin, the sunlight has little effect on them. Diffuse light, such as is present where the direct rays of the sun do not penetrate, is very weak in its action, requiring hours and days to produce the same effect as a few moments of direct sunlight. It is very certain that sunlight under the conditions that obtain in barns and stables has but little disinfecting action, because of the fact that the bacteria are protected from its action by the dirt and dust.

Another physical agent of which little use can be made in the disinfection of stables is heat, either as dry heat or in the form of steam or hot water. Any small object of wood or iron ean be easily disinfected by boiling. Thus, in the case of contagious diseases of human beings, this process is frequently used. In the disinfection of stables etc., one is limited to the use of chemicals.

Chemical disinfectants. The chemicals used for disinfection may be divided into two classes, solid materials used in suspension or in solution, and gaseous. The latter are by far the best when the conditions will permit of tneir use for the gas penetrates to every part of the space to be treated, even into cracks and crevices. This fact makes their use impossible except in a space that can be tightly closed, for the gas must be confined for several 
hours in the space to be disinfected in order that the process shall be effective. The gaseous disinfectants find their greatest use in household disinfection, where the rooms can be tightly closed by pasting strips of paper over the door and window cracks. Formaldehyde, the best gaseous disinfectant, finds but limited use in the stable. Reliance must here be placed on the disinfectants that can be applied in solution or suspension in water. There are a considerable number of these but three or four are by far the most important.

Lime. Quick lime or stone lime is made by heating lime stone to a very high temperature. The lime stone is changed because of the loss of carbon dioxide, which passes off as a gas during the burning of the lime stone. The quick lime thus produced gradually changes on exposure, to a powder known as air-slaked lime which has the same composition as the original lime stone, and which has no disinfecting action whatever. If the quick lime is: treated with six parts of water to ten parts of lime, water-slaked lime will be obtained, which, when prepared in a cormet manner, is a dry white powder, resembling air-slaked lime in appearance but not in composition. This ean be noted by placing a particle of each on the tongue for a moment. The air-slaked lime tastes like so much chalk while the water-slaked soon causes the tongue to burn. It is caustic lime and has disinfecting properties. It can be used as a dry powder, sprinkled on floors and yards, or in a suspension in water as whitewash. The whitewash is best applied with a spray pump and for this purpose must be made rather thin so as not to clog the nozzle of the pump. Any of the hand spraying outfits are well adapted for the application of whitewash or other disinfectants to the walls and ceilings of stables. 
Lime is cheap, and can be procured everywhere. If the whitewash is prepared from good lime, its disinfecting properties are probably as great as those of any other substance that can be used to advantage in stable disinfection. It has, however, little effect on spores of bacteria. The whitewashed walls and ceilings make the stable much lighter than would otherwise be the case. The dry water-slaked lime is especially valuable for the treatment of yards and pens infected with hog cholera bacilli and for covering the carcasses of all animals that have died of any of the transmissible diseases, and which are to be buried.

Carbolic acid and cresol compounds. Carbolic acid appears on the market in the crude and purified forms. The former is a black, oily liquid that will not mix with water, unless treated with strong acids, such as sulphuric acid, or with strong alkalies. The pure earbolic acid is in the form of white crystals, which on the addition of 5 per cent of water, and on warming, changes to a clear liçuid of the consistency of syrup. For use as a general disinfectant, this liquid is added to water so as to make a 5 per cent solution. A stronger solution than this will not dissolve in water.

Both the crude and purified carbolic acid are being replaced for disinfection purposes by the different proprietary compounds such as Zenoleum, Kresol, etc. These substances have, as a rule, greater disinfecting powers than carbolic acid, a 2 per cent solution being as effective as a 5 per cent solution of carbolic acid. They mix with water in all proportions, forming a milky white emulsion that can be easily applied with a brush or spray pump. They are less caustic and poisonous than carbolic acid, but their cost is somewhat more. 
Corrosive sublimate. This compound, frequently called bichloride of mercury, is the strongest disinfectant known. Its great disadvantage as a stable disinfectant is its poisonous properties, which preclude its use on mangers. It is used in a one to one thousand solution, one ounce in eight gallons of water. It kills all forms of bacteria in a moment and the spores in a short time when no substance is present that will combine with it and thus destroy its action on the bacteria. In the presence of dirt and manure its effect is greatly reduced.

Ferrous sulphate and copper sulphate. These substances known as green and blue vitriol, respectively, were formerly considered to be good disinfectants. It is now known that they are almost worthless in this respect. They are rather to be classed as deodorants, and can often be used for this purpose to good advantage. A substance that will counteract the odors produced by bacteria does not necessarily destroy the bacteria themselves.

Formaldehyde. This disinfectant is sold as a solution of the gas, formalin, in water. It can be applied as a 5 per cent solution, but since the gas at once passes off, it has but little value as a stable disinfectant. Small objects, other than those of leather, to be disinfected can be placed in a solution of formaldehyde.

The process of stable disinfection. Whenever a stable is to be disinfected, the first process should be to give it a thorough cleaning. It should be remembered that no disinfectant can kill a disease-producing organism with which it does not actually come in contact. If the organism is protected by dust, dirt, and dried manure, its destruction is difficult. The most of the disease-pro- 
ducing germs will be in the dirt and manure of the stable. If the stable is thoroughly cleaned most of the bacteria will have been removed.

All loose woodwork, especially box mangers, should be removed. The walls, ceilings, and floors should be moistened by spraying with a solution of corrosive sublimate so as to prevent dust in the, subsequent operations. The loose material should all be removed; the walls and floors scraped until all dried manure and dirt is removed and the bare wood or concrete exposed. All the material removed should be burned, not thrown into the yard with the cattle. The stable should now receive a good coat of whitewash applied with a spray pump so that it will penetrate all cracks. Both walls and ceilings should be treated, and the floors sprinkled with the dry water-slaked lime. The mangers should be, scrubbed with a hot solution of lye, or a 5 per cent solution of carbolic acid. The actual process of disinfection should be supplemented by making provision for abundant, light and air. A halfhearted job of disinfection is worse than none at all, since it gives a fancied security, but little real security against a re-occurrence of the disease.

The disinfection of yards is difficult. It can only be attempted. The sprinkling of a liberal amount of dry water-slaked lime is the best that can be done. The disinfection of fields is impossible. Small areas may be limed or burned over. Neither of these methods is likely to be effective in the case of spore-forming bactria. All other forms will soon die without the addition of any disinfectant. 
SECTION IV.

\section{RELATION OF BACTERIA TO SOIL.}

\section{CHAPTER XIX.}

\section{RELATION OF BACTERIA TO FERTILITY.}

The farmer is interested in the soil as the home of the plant. Unless its home is one favorable in every way to the kind of plants the farmer is attempting to grow but meager yields will reward his efforts. In order that the soil shall be a favorable place for such growth, a number of conditions must be present. Its physical properties are important. It must not be hard and dense so that the delicate roots of the young plant in search of food cannot make their way through it. It must be in good tilth. Moisture, not too abundant or too small in arnount, must be available. The temperature of the soil must be conducive to rapid plant growth. These things are all important and are to a great extent at least under the control of the farmer.

- Plant food. Another important condition required is the presence of a sufficient supply of plant food in an available form for use by the plant. Certain chemical elements as potassium, calcium, magnesium, phosphorus, nitrogen, sulphur, and iron are essential in order that normal development may occur. These substances the plant obtains from the soil. The carbon, oxygen, and 
hydrogen which are as essential as the other chemical elements mentioned are always abundantly present in an available form in the water and in the air.

The elements obtainable from the soil are a greater source of worry to the farmer. While the soil, as a rule, contains large amounts of these different elements, they may be present in such forms that they cannot be utilized by the green plant. While they represent plant food, it is of no immediate value because unavailable. This material is, however, undergoing a change in form that renders it more and more available. A large number of agencies are at work, causing this change and amongst them biological factors are very important.

As indicating the relatively large amount of unavailable plant food that may be present, the following analysis of 49 American soils are presented. The total nitrogen, phosphorus and potash content of the first eight inches was as follows: 2600 pounds of nitrogen per acre, 2090 pounds of phosphorus, and 7400 pounds of potassium. The other essential elements are usually present in larger amounts and therefore are not so likely to be depleted in the soil as are the three mentioned.

The amount of any of these elements that are available at any one time is usually very small indeed. Often, it is not enough to furnish what is needed for a single crop. The potential but immediately unavailable supply must be constantly changed into available food at a rate sufficiently rapid to supply the plant so that growth may go on rapidly or otherwise the crop will be a poor one. A fertile soil may, in one sense, be defined as one in which unavailable plant food is being changed to available food at such a rate that there is an abundant supply at all 
times to allow of a rapid and luxuriant growth of the plants.

The food to be available to the plant must be in solution so that it can pass into the roots of the plant. Such soluble material is easily lost in the drainage water that leaches from the soil during the wet times of the year. Thus, if more of any one element is made available than the crop ean use, it is very likely to be lost during the winter and spring, and the soil thus robbed of its fertility. An ideal condition is to have enough of each element rendered available so as to ensure an abundant crop, but not to have an excess. This ideal condition cannot be realized but much can be done by the farmer to conserve the fertility of his soil by methods which will be mentioned later.

If any one of the essential elements is lacking, or is present only in small amounts in available form, it will act as a limiting factor to the yield. One element is as essential as another. Any may be the limiting one. If this be added to the soil in the form of a fertilizer, an immediate increase in yield is noted. For this reason the use of commercial fertilizers is so extensive. The fertility can also be restored by treating the soil in such a way as to render the unavailable plant food available. For example, it has been shown in certain of the wheat fields of the Rothamsted Experiment Station in England that the amount of available phosphorous present in the soil was so small as to limit the yield, yet this same soil contained a large amount of the element in an insoluble form. By treating the soil in a proper manner so as to allow the growth of certain kinds of bacteria, the phosphorus would be made soluble and the fertility of the soil improved. 
The same is true with reference to the other essential elements. It thus becomes important to know something concerning the conditions that are favorable for the growth of the bacteria in the soil. The yield of the visible crop is dependent on the way in which the farmer favors the growth of the invisible crop. This presents a new phase of soil management which has not long been recognized, as the soil has generally been regarded as an inert mass of particles of sand, clay, or gravel, internixed with more or less dead organic matter which gave to the upper portion its black color.

Since there is no store of available plant food in the soil and since the bacteria are necessary in order to change the raw food to a fitting form, it is evident that a soil that is free from bacteria cannot be a fertile one. If various types of soils are examined as to the number of bacteria, it will be found that those of high fertility are teeming with bacteria while a poor sandy soil will rontain very few.

Distribution of bacteria in the soil. The soil is one of the great homes of the bacteria. In a state of nature, i. e., in uncultivated soil, everything that the soil yields is returned to it, either directly in the form of the dead plant, or indirectly in the body or excreta of an animal that has lived on the plants. This means that organic matter in abundance is supplied as food to the bacteria; hence their rapid increase in numbers where requisite conditions obtain. This activity renders still more raw plant food available with the result that the soil continues to increase in fertility until there have been formed from the bare rock by the aid of various physical agencies that help in disintegrating the rock such fertile soils as are found on our western prairies. 
It is impossible to determine in any way the total number of bacteria in the soil. What can be done is to determine the number that will grow on such substances as are used in the laboratory as culture media. Examined in this way a sandy soil will be found to contain a few hundred thousands in each gram (1-30 of an ounce) while a rich loamy soil may contain several million per gram. A garden soil may show ten, twenty-five, or even fifty millions of these minute plants so essential to the fertility of the soil. The greatest number of bacteria is found in the first few inches of the soil, in what is known as the soil proper. In the sub-soil smaller numbers are found and as still lower depths are examined the bacteria decrease rapidly in numbers. At a depth of a few feet they completely disappear. The reason for this rapid decrease in numbers is due to the lack of food and air, and to the filtering effect of the soil. In the upper layers of the soil food is abundant and other growth conditions favorable.

The soil contains a large number of different kinds of bacteria of the most varied nature and appearance. It is the home of some of those that produce diseases in man and animals, as well as the most of those forms that cause the spoiling of food substances, and the various fermentations, many of which are so important. The number of bacteria in the soil is influenced by a number of factors, chief of which is the amount of food present. The addition of organic matter in the form of stable manure, or plowing under a green crop, increases the amount of food material, thus stimulating the growth of bacteria.

The effect of temperature is also of importance. As the soil becomes warm in the spring, the conditions become more favorable and the bacteria increase rapidly in 
numbers. The rise in temperature has more effect at this time of the year than later, since the supply of available food is likely to be greater than during the summer anil fall, due to the fact that the remains of the previous: crop are added to the soil.

The moisture content also exerts an influence. Bacteria demand a considerable amount of water for their growth. If the soil is very dry, cell development is slow or ceases. Again, if the soil is water logged as in marshes and low lands, the growth of certain essential kinds of bacteria is impossible, due to the fact that they cannot get a supply of oxygen. Such wet soils warm upvery slowly and this acts as a restraining factor in bacterial growth. If the low places are drained, the excess of water is removed and air is allowed to penetrate the soil and bacterial action is more rapid, both because of increased aeration and higher temperature. The effect of an abundant supply of oxygen is to increase the growth of the most important classes of soil bacteria as is noted in soils thoroughly cultivated. Permanent pasture and woodland soils are poorly aerated and in them certain kinds of bacteria grow poorly. As a result these lands never produce such large amounts of plant growth each year as does the same soil under cultivation.

The bacteria as a rule grow best in an alkaline medium, and this is especially true of many soil bacteria. The soils of marshes and lowlands in general is apt to be acid in reaction. Soils that have been cultivated for long: periods without having had returned to them organic matter, barnyard or green manures, tend to become acid. In such soils the bacteria cannot grow well. If the acidity is neutralized by the addition of lime, the number of bacteria will increase. In an acid soil, the addition of 
4000 pounds of limestone per acre increased the number of bacteria from 440,000 per gram to $6,600,000$ in a period of seven weeks.

It will be seen that whatever makes the soil a better home for our cultivated plants, increases the number of bacteria in it. The question at once comes to mind: Is the increased fertility as shown by the larger crop, the cause of the growth of the microseopic plants, or is the rapid growth of the bacteria the eause of greater fertility, and hence the larger crop of corn or oats, etc. results? As will be seen, the latter is the true statement. Without great bacterial activity in the soil, large crops cannot be grown.

Higher forms of life in the soil. Bacteria are not the only forms of life that live in the soil and exert an effect on its properties. In acid soils, molds may grow luxuriantly. The soil also contains various kinds of tiny green plants found so abundantly in water, the green algae. Still larger forms of life are of great importance, such as the common angle worm, that, by its formation of burrows, brings the lower layers of the soil to the surface, and thus in the course of a few years, turns the soil over as completely as does the farmer's plow. The burrows allow the air to penetrate into the soil. The land under permanent grass is thus aerated and cultivated by these animal forms. These and all other low animal forms live on organic matter; they help to decompose it, and are in turn decomposed by bacteria. Statistics that have been collected indicate that each acre of land supports as much life, measured in pounds, in the shape of low animal forms, as the farmer keeps in the form of domestic animals.

The soil is, thus, not a dead and inert mass, but some- 
thing teeming with forms of life of the greatest importance to the farmer. It is a manufacturing establishment where plant food is made from raw materials. To furnish the workers favorable conditions is one of the problems the successful tiller of the soil must solve.

Decomposition of organic matter. The material returned to the soil under natural conditions or by the farmer in the form of stable manure or the crops plowed under (green manuring) is organic in character, i. e., the result of plant and animal growth. It contains the elements that are necessary for succeeding crops of vegetation, but in such a form that they cannot be used until they have again been brought to the same condition as when they were first taken up by the plant.

The organic matter added to the soil embraces every conceivable type of matter, yet, everything serves as a food for some form of life, and is thus decomposed to some extent. Other kinds of life then use the by-products of the first and so on until the ultimate stage is reached and the elements can be again made use of by a new crop of wheat, corn, or other plant. The spoiling of our food stuffs, rotting of apples, and potatoes, the souring of milk, the putrefaction of meat, and the rotting of manure, are but steps in this great series of decomposition processes carried on largely by bacteria.

The digestive changes occurring in all kinds of animals are but initial steps in the decomposition of organic matter, since the material given off from their bodies is much more simple than the food absorbed and is much more easily brought, by the action of bacteria, into a form that can be used by the green plant.

The various kinds of matter added to the soil can be divided into three classes: 1 st. The carbohydrates; 2 nd. 
the protein substances, and 3rd. the fats. The first are composed of carbon, hydrogen, and oxygen and include such substances as starch, sugars, cellulose, and woody fiber; the third is made up of the same elements, and is represented by the animal and vegetable fats and oils. When these substances are completely decomposed, the elements appear as water, and carbon dioxid $\left(\mathrm{CO}_{2}\right)$, both of which can be used by the plant.

Protein material contains in addition to the above elements nitrogen, sulphur, and phosphorus. The end products of their decomposition are carbon dioxid, water, ammonia, free nitrogen, hydrogen sulfide, and some compound of phosphorous. The ammonia, hydrogen sulfide, and phosphorous compounds must be further changed by certain kinds of bacteria before the green plant can use the nitrogen, the sulphur or the phosphorus.

The simple end products, carbon dioxid and water, of the bacterial decomposition of organic matter do not interest us further. The compounds that are formed during the stages of decomposition are of more importance because of their influence on the soil.

The decomposition is earried on by both aerobic and anaerobic forms of bacteria. The great distinction between their work is that the work of the first is complete; the most simple products resulting, such as carbon dioxid, water, and ammonia. The material acted upon disappears as completely as though it had been burned. With the anaerobic bacteria the work is not wholly finished, but a part of the material remains in the soil, and forms what is known as humus.

Because of the fact that in cultivated soil, conditions are favorable for the aerobic bacteria, humus does not 
accumulate. On the other hand in land under grass, in woodland and in wet lands the anaerobic bacteria grow best. Here the decomposition of the vegetable residue is not complete and the humus accumulates in the soil. When the lowland is drained, or the prairie broken, the acrobic bacteria begin to act on the humus, and gradually destroy it. The land now produces more than in its wild state, but unless organic matter is returned to it as manure, etc., it gradually diminishes in fertility, as has been so well shown in the eastern part of the United States. The burning of the straw on the prairies of Minnesota and Dakota is one way in which the fertility of the land is destroyed. The straw, if it had been plowed under, would have helped to keep up the humus content of the soil. It would have furnished the bacteria food, and the result would have been a much less rapid decrease in fertility in those fields, the soil of which the settlers thought could never be exhausted.

In a sandy soil, the aerobic bacteria grow rapidly and any organic matter added is soon completely destroyed; while in a close soil like a clay, the decomposition processes go on much more slowly. The effect of a heavy coating of manure is often to be noted only during the season in which it is applied to a sandy soil, while on a clay soil it may manifest its effect in the second and eren in the third year.

In some kinds of farming, the farmer cares little for the fertility of the soil, but wishes one that will allow the rapid growth of bacteria which are to decompose the manure that is added. The market gardener, with an abundant supply of manure from the city, wishes such a soil, simply a place for the bacteria to work on the raw material he adds to the soil. 
The green plant gets its supply of carbon from the carbon dioxide of the air. Only a small amount is present in the air at any one time, so little in fact that if the supply were not renewed it would soon be exhausted. This renewal comes from the decomposition of organic matter by bacteria. The respiration of plants and animals also produces carbon dioxide. The burning of fuel also frees the carbon as carbon dioxide. There is thus a constant passing of the carbon from the air to the plant and back again to the air through the action of plants, animals and especially the bacteria of soil. 


\section{CHAPTER XX.}

\section{EFFECT OF BACTERIA ON MINERALS OF THE SOIL.}

The water that falls on the soil in the form of rain contains no mineral matter in solution. If the water from a well or that which runs from a drain is examined, it will be found to contain a varying amount of material that has been dissolved from the soil through which the water has passed. Most of the mass of the soil is insoluble in pure water, hence there should be found but a very small amount of mineral matter in the drainage water unless there are factors at work in the soil, changing the insoluble minerals into soluble compounds. It has been seen that the bacteria render the various kinds of organic matter soluble, and that the products formed by their action are water, ammonia, and carbon dioxide together with some less important products. Many intermediate products are formed in the decomposition of organic matter that have a great effect on the mineral part of the soil.

In the decomposition of such organic substances as sugars, starches, and related compounds, acids are formed, as lactic, acetic, and butyric. Carbon dioxide when dissolved in water acts as a weak acid. All of these acids have a solvent effect on the different minerals of the soil. In the process of nitrification a strong acid is formed, nitric acid, which also has an effect on the soil particles. 
Calcium. This important element is present in the soil in the form of calcium carbonate or lime stone, which is insoluble in pure water, but owing to the presence of carbon dioxide and organic acids in the soil, the water percolating through the soil carries with it more or less calcium carbonate. The water which comes in contact with beds of lime stone is called "hard" water because it carries in solution such large quantities of calcium carbonate. The greater the amount of organic matter added to the soil, the greater will be the quantity of car. bon dioxide and organic acids formed by bacterial action and the more rapidly will the lime be removed from the soil.

On account of this constant solution of lime, the soil tends to become acid, which condition becomes unfavorable for bacterial action and the soil is no longer fertile. The farmer finds it necessary to correct this acid condition by adding lime to the soil in the form of crushed lime stone.

The dissolved lime passes off in the drainage water to the sea, where it is used by marine animals in forming their shells. As these organisms die they gradually sink to the bottom of the sea, forming beds of lime stone. In some great movement of the crust of the earth these are raised above the surface, and are subjected to the action of weathering and influence of biological changes. Thus the movement of lime from land to sea and sea to land goes on.

Phosphorus. The phosphorus of the soil is largely in the form of calcium phosphate, which, like calcium carbonate, is insoluble in pure water but which is easily dissolved in water which is acid in reaction. Even carbonic acid will change it to a soluble form in the same way: 
that lime stone is made soluble. Phosphorus is thus constantly lost from the soil.

The fertility of soil may be limited through the fact that the soil does not contain phosphorus in any form, or because the phosphorus it does contain is not rendered arailable by solution. Phosphorus may be added to the scil in the form of bone-meal, phosphate rock (floats, or calcium phosphate), superphosphate (acid phosphate). Of these only the last is immediately available to the plant, as the other compounds are the same as the phosphorus already present in the soil. Their addition alone to a soil that is lacking in available phosphorus has no effect whatever. If added in connection with a large amount of organic matter, as barn yard manure, or a crop that is plowed under, the insoluble phosphates are made available because the organic material furmishes food for the bacteria, which as a result of their growth form acids that render soluble the calcium phosphate. The addition of rock phosphate to sandy land or to land low in humus is of little use. Sprinkling "floats" on the manure as it is made is an excellent way of adding the phosphate to the soil. The insoluble phosphate is thus brought in intimate contact with decomposing organic matter and is gradually rendered soluble.

There is need of an abundant supply of available phosphorus in the soil not only for the green plant but for some forms of bacteria that are very beneficial to the farmer. The different kinds of nitrogen-fixing bacteria, both those that grow in the nodules of the leguminous plants and those in the soil itself, develop most luxuriantly only when phosphorus is available.

The fertility of a soil may be low because the phosphorus it contains is not being rendered available. Un- 
der such conditions, the question of fertility may not be affected so much by the addition of more phosphate as by the incorporation of organic matter that will render available the phosphorus which is already present in the soil.

Potassium. The content of soils in this important element is usually very high. A soil may contain many thousand pounds of potassium per acre and yet so little of it be made available to the plant that the soil will respond to the addition of a potash fertilizer. Potassium is rendered soluble by bacterial action in the same manner as are calcium and phosphorus. The growth of the nitrogen-fixing bacteria is possible only when potassium is available.

Sulphur. The sulphur that is taken from the soil by the green plant in the form of calcium, potassium or sodium sulphate is rendered available to the plant once more through the action of bacteria. When organic matter, either of plant or animal origin, undergoes decomposition, the sulphur is changed into hydrogen sulphide, a gas that is one of the causes of the offensive odors coming from putrefying materials. This gas is poisonous to the green plant. It is, however, utilized by the sulphur bacteria which are found most abundantly in sulphur springs. They also occur in the soil where they use the hydrogen sulphide formed from decomposing matter, changing it to sulphates, the form in which it can be again used by the plant.

The characteristic odor of the soil has been shown to be due to a compound formed by the growth of a certain class of bacteria in the soil. 


\section{CHAPTER XXI.}

\section{AMMONIFICATION, NITRIFICATION AND DENIT- RIFICATION.}

The green plant takes the carbon that it needs for its growth from the air in the form of carbon dioxide. During each growing period there is an immense amount of this compound removed from the air, but which however is constantly replenished by various factors among which the bacteria are very important. Through the work of micro-organisms and the respiration of plants and animals the carbon bound up in the organic matter is again made ready for the use of the plant.

The nitrogen that the plant demands for its growth is taken from the soil in the form of nitrates. The amount of combined nitrogen in the soil is small, and unless there are factors at work that shall restore the nitrogen found in the bodies of plants and animals to a form in which it can again be used by the plant, the soil would soon be depleted of this element. The immense amount of free nitrogen in the air, amounting to at least 35,000 tons over each acre, is not available for the green plant, except under special conditions that will be discussed in a subsequent chapter.

The nitrogen of the soil is in the humus and is not available to the plant but must be worked over and changed to a form in which the green plant ean use it, just as the nitrogen added to the soil in the green crop or in manure must pass through a complex series of changes to be of use to the plant again. 
Ammonification. When organic matter containing nitrogen is decomposed by bacterial action, a part of the nitrogen is returned to the air as free nitrogen. This is of course lost so far as the soil is concerned. The larger part of the nitrogen is changed to ammonia after passing through a complex series of changes. The presence of ammonia can often be noted about heaps of decomposing matter, especially piles of horse manure. The production of ammonia from organic matter is due to the work of many classes of bacteria widely distributed in the soil. These bacteria belong to both the aerobic and anaerobic classes, thus making possible the process of ammonification under widely diverse conditions as to presence or absence of oxygen. There is usually no lack of some of the various kinds of ammonifying bacteria in the soil, and the conditions under which they work are so varied that the farmer does not have to consider means of favoring their action. The work which they do is absclutely essential to the fertility of the soil, since it is one of the steps in the transformation of the nitrogen to an available form for the plant. Soils have been studied in which it was thought that the cause of the low fertility was the lack of ammonifying bacteria.

Nitrification. Under the action of these bacteria the nitrogen of decomposing matter is rapidly changed to ammonia. Plants ean not use nitrogen in this form to advantage.' Some kinds of plants can cover part of their need for nitrogen from this source, others can not use ammonia at all. It is therefore necessary for the nitrogen to be still farther changed by the action of specific organisms, the nitrifying bacteria. There are to be found in nearly every soil two classes of the nitrifying organisms, one which changes the nitrogen of ammonia to ni- 
trous acid, the other the nitrous acid to nitric acid which when combined with lime forms calcium nitrate. If the second class of bacteria is not present in the soil, it can not be fertile, since plants can not make use of nitrogen in the form of nitrites.

The absence or limited amount in the soil of any of the elements necessary for plant growth may be the cause of the low fertility of a soil. The condition most likely to be associated with a reduced yield is lack of nitrogen. The nitrates are very soluble in water and are easily leached from the soil. Those formed during one season are removed during the winter and spring, and as there is no accumulation of available nitrogen in the soil the supply is rarely much in excess of the needs of the plant. It is thus necessary that enough nitrogen be rendered available during the growing season to supply the needs of a luxuriant crop. If the process of nitrification is retarded, the crop will be a meager one. It is of the greatest importance that the farmer be acquainted with the conditions that favor the process of nitrification in the soil, for unless the crop of nitrifying bacteria in his soil is large, the yield of corn, oats, etc., can not be a profitable one.

Conditions for nitrification. The nitrifying bacteria are aerobic. They grow best in an open textured and well aerated soil. In one that is close and dense, the process of nitrification is retarded; in a water logged soil it does not go at all. By draining a field the water is removed, air is drawn into the soil and nitrification goes on rapidly. Cultivation also allows the air to penetrate the soil more thoroughly and favors nitrification. It will be noted that the largest yields are in the case of the socalled eultivated crops rather than with the grasses and 
grains. This is due in no small measure to the larger amount of nitrogen rendered available because of the favorable conditions for the nitrate-forming bacteria in soil which is frequently stirred.

It is essential that the soil shall contain some substance, as lime, to combine with the nitric acid formed, otherwise the soil soon becomes acid and nitrification is no longer possible. In a marshy soil the process may go on slowly or not at all. If an application of lime is made and the acidity neutralized, nitrification begins. In such a soil the process is also favored by drainage and cultivation since the aerobic forms of life gradually destroy the acid products that have been formed by the anaerobic bacteria.

The change of ammonia to nitrates can not go on in the presence of large amounts of organic matter, as for example in a manure heap. The nitrifying bacteria are unable to grow in a very dry soil. The process of nitrification reaches its maxium in the soil during the summer, especially during June and July, when the need of the growing crop for nitrates is greatest. It goes on, however, during the fall and to some extent as long as the ground is not frozen. The reason for the greater rapidity of the formation of nitrates during the early summer is found in the favorable temperature conditions, together with the large amount of ammonia that is formed from the decomposition of the previous year's crop.

The sodium nitrate that is used for fertilizer and in the chemical industries is obtained in Chile where there are large deposits. These are supposed to have been formed by the decomposition of sea weed under such conditions that the resulting nitrate was not leached away. Im- 
mense amounts of nitrates are used in the manufacture of explosives as gun powder, nitroglycerine, etc. Before the discovery of the Chilean deposits, the nitrate needed for such purposes was largely made on the saltpeter plantations. A mixture of earth and organic matter of any kind was made and placed in a pile which was protected from leaching. The air was allowed access to the inside of the pile by placing brush wood in it. The nitric acid formed was neutralized by mixing lime stone with the soil or by the addition of soapy water. When the process was completed, the entire pile was leached and the nitrate obtained by evaporating the water. The deposits in Chile will soon be exhausted, but it is certain that methods will be found by which the nitrogen of the air can be brought into combination as nitrates, and it will not be necessary to rely on the action of bacteria for the nitric acid needed in the industries, and as fertilizers. The farmer must always depend upon the action of this class of bacteria in order to obtain the nitrates needed by the various crops grown by him.

Denitrification. In the broadest sense denitrification may include any process due to micro-organisms by which the nitrogen available to the plant, i. e., that contained in nitrates, is changed so that it is less available or rendered unavailable. There are a number of processes by which this is accomplished. The process may be the reverse of nitrification, the nitrates being reduced to nitrites and to ammonia. The bacteria responsible for this action can act only in the absence of air and, while they are always present in the soil, they do not usually manifest themselves. During a wet spell in the summer, the soil may be so saturated with water and hence contain so little air that these bacteria can destroy the nitrates pres- 
ent. If the wet weather continues for any length of time, the crops, especially those that need large amounts of nitrates and can not use nitrogen in the form of ammonia at all, begin to suffer from nitrogen hunger which is shown by the yellow color of the leaves in place of the dark green of the well nourished plant. As soon as the water leaches from the soil and air is drawn into the same, the nitrifying bacteria change the nitrites and ammonia back to nitrates. In the lower parts of a field the conditions favorable for denitrification may continue so long that the crop is permanently injured. This property of reducing nitrates is a very common one among the soil bacteria.

In the process just described the nitrogen is not permanently lost. A more important process is one in which, by the action of bacteria, the nitrogen of nitrates is set free and passes into the air. The bacteria able to do this are always present in the soil. They demand for their action the absence of oxygen, and an abundance of organic matter, as well as the presence of nitrates. They are of small significance in the soil for the conditions necessary for their action are not likely to obtain. They are especially abundant in fresh manure, but much less so in rotted manure. If a large amount of manure is added to the soil together with sodium nitrate, as may be done in gardening or in green house work, the nitrate may be destroyed by the action of this class of bacteria.

It will be seen that the conditions favoring dentrification are the opposite of those favorable to nitrification. The farmer by frequent cultivation, by drainage, and by maintaining the soil in good tilth, favors the beneficial process and retards the harmful one. It is fortunate that those conditions that are most favorable for the for- 
mation of nitrates are the ones that are naturally demanded by the green plant in normal growth.

Some of the soil bacteria derive their supply of nitrogen from the same source as do the green plants, i. e., the nitrates. If these forms are abundant in the soil, they will compete with the plants for the nitrate present. Since, as has been indicated, the nitrogen is most often the limiting factor in plant growth, it is important that as much of it be reserved for the crop as possible. The presence of weeds in the field may limit the crop because they use a portion of the nitrogen that would otherwise be available for the crop. The bacteria that use the nitrogen of nitrates may limit the crop in the same manner. The conditions that favor their action and their importance in the soil are problems yet unsolved.

During the decomposition of organic matter of all kinds some of the nitrogen is set free. It is not known that the farmer can prevent this in the soil, but in the handling of the most important by-product of the farm, the manure, much can be done to avoid this loss.

Conservation of nitrogen. It is desirable to conserve the supply of nitrogen in the soil as much as possible since to restore the nitrogen supply is a slow process when the natural factors are relied on, while to furnish the amount needed by a crop in the form of commercial fertilizers would be too expensive.

During the growing season nitrates are being constantly formed and are as rapidly used by the crop. In the more fertile soils a greater amount of nitrate may be formed than is needed by the plant. Some of this is taken up by the plant but it not used. It accumulates in the tissues as potassium nitrate. It has been thought by some that the corn stalk disease previously described 
was due to poisoning by the large amounts of this compound in the corn. While this is probably not true, the excess of nitrate taken up by the plant not only makes the corn fodder less valuable but depletes the soil of nitrogen. The nitrate not taken up by the plant is leached from the soil during the winter and spring and is lost.

The ideal condition would be to have the nitrates formed at the time they are needed by the plant and to have no excess. But this is not possible, an excess must be formed in order to obtain a maximum crop since the roots of the plants do not reach each soil particle. It is estimated that for each pound of nitrogen removed from the soil in the crop, four pounds are lost in drainage water. The farmer can do something to conserve the nitrogen of his soil. If a crop has been removed in late summer or early fall, there will be nothing to use the nitrate that will be formed, hence it will be lost during the winter. If a cover crop had been planted it would have absorbed the nitrate, building the nitrogen up into its tissue and preventing its loss from the soil. If the cover crop is plowed under in the spring, it will be decomposed, and not only the nitrogen it contains, but the phosphorus and potash as well, rendered available for the next crop. In orchards not under sod the cover crop is especially beneficial. If the cover crop is one of the leguminous plants, the soil may even be enriched in nitrogen as will be seen later.

It is now recognized that the process of fallowing the land is an excellent means of robbing the soil of its nitrogen because, while the soil is bare, the frequent stirring establishes favorable conditions for nitrification, but as there is no crop present to use the nitrates which are formed they are lost in the drainage water. 
The material that is turned under in the cover crop furnishes food for innumerable bacteria, and by-products of their growth act on the mineral part of the soil, rendering the lime, potassium, and phosphorus available to the green plant. It also furnishes food for a class of bacteria to be described in a subsequent chapter that aid in maintaining the nitrogen content of the soil. A part of the organic matter of the crop plowed under accumulates in the soil as humus which has a most favorable effect on the physical condition of the soil. In the conservation of the nitrogen of the soil it is apparent that the best practice is not to allow the land to lie idle, but to keep it covered with a crop. 


\section{CHAPTER XXII.}

\section{FIXATION OF NITROGEN.}

At the time when life first appeared on the earth the soil, of course, contained no organic matter for such material is the product of living things, plants and animals. The soil was presumably composed of clay, sand, and gravel, the result of the processes of disintegration of the original rocks of which the earth was composed. During the thousands and thousands of years that have passed, organic matter has been accumulating in the soil because all of the material that the soil produced, vegetable or animal, was returned to it. This material has been decomposed by the bacteria and other forms of life with the production of the various substances that have been previously mentioned. A part of the organic matter has not been completely decomposed, but remains in the soil in the material called humus. On account of its effect on the physical properties of the soil, and because it is a source of nitrogen, humus is one of the most important constituents of the soil. It is not certain that the soil at the time life began to exist on the earth contained any nitrogen. The question at once arises as to how the present store of nitrogen found in the soil has been gathered from the air.

It is evident that soils under natural conditions tend to accumulate nitrogen until some of them contain such large amounts as are found in the soils of our western prairies. Under artificial conditions, as under cultiva- 
tion, the soil tends to become poorer and poorer in nitrogen, because the supply of this element is being used by succeeding crops of plant life, and unless some means are taken to restore the supply, the soil soon becomes a barren one. If every thing that the soil produced was returned to it, its fertility could be maintained indefinitely. The soil in certain parts of Japan and China has been cultivated for thousands of years and is today as fertile as ever because every bit of the waste matter of human and animal life has been returned to it, and has not been sent down to the sea in the form of sewage or exported to other lands in the form of raw and manufactured products, as is being done in our own country. It seems impractical for us to be as careful as are the peoples mentioned in returning to the soil all waste matter. Yet it is absolutely necessary for us to maintain the nitrogen supply of the soil in every possible way, for this is the element that is most likely to be lost, and the one which is the most costly to replace in the form of commercial fertilizers.

The air, composed as it is of four-fifths of nitrogen and one fifth of oxygen, furnishes the source from which it becomes possible to draw unlimited supplies of nitrogen. The nitrogen of the air is not directly available for most green plants. It is, however, much more economical for the farmer to learn how to utilize this supply than to rely for his store of nitrogen on the commercial fertilizers that may be purchased.

Fixation of nitrogen. Within the last few years methods for the fixation of the nitrogen of the air by electrical means have been perfected. Where cheap power can be procured, as near water-falls, nitrogenous fertilizers can be made cheap enough to compete with the 
natural product from Chile. It is thus certain that life will never cease to exist on the earth because the supply of combined nitrogen has been used up for the illimitable store of the free nitrogen of the air will always serve as a supply in the future as it has in the past. Present farm practice, however, in the hands of many is blindly robbing the soil of these accumulations by natural agencies; in other words we are living on the capital which has been stored up. When so handled,-it is only a question of time before our capital will be exhausted, and then reliance must be placed on the nitrogen that is returned to the soil in the form of manures and on that fixed by natural means, in order to furnish the necessary amount for the crops.

A consideration therefore of the natural agencies that are fixing nitrogen in the soil and elsewhere is important and especially those that are susceptible of control by man. Every flash of lightning causes some of the nitrogen of the air to combine with oxygen, forming, with the water in the air, nitric acid which is brought to the soil in the rain water. In this way a small amount of nitrogen is added to every acre each year but a comparatively inappreciable quantity when compared with the needs of the crop.

The most important agencies, however, that are concerned in the fixation of nitrogen of the air are the bacteria that are found in every soil. There are three types known at the present time, one of which fixes nitrogen by the help of a certain kind of green plants, the legumes, the remaining kinds being able to do so independently. If conditions are not favorable for the growth of these bacteria in the soil practically no increase in nitrogen will occur. It is thus essential to learn what conditions 
favor their growth and to seek to establish such in the soil.

Leguminous plants. It has been known since the days of the early Romans that leguminous plants had a favorable effect on the soil and for this reason they were included in nearly all systems of crop rotation. This favorable effect of the legumes was explained in many ways. Some claimed that because of their deep roots, they were able to reach plant food that was ordinarily

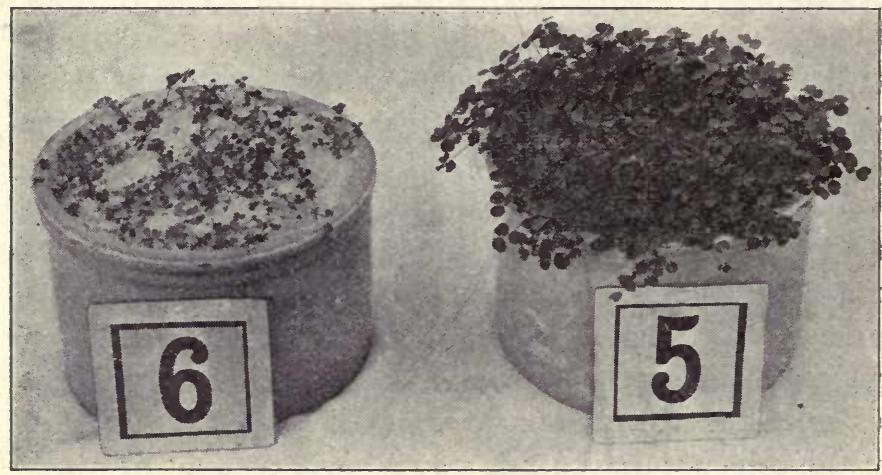

Fig. 19.-Leguminous Plants.

Clover growing in soil free from nitrogen. In jar No. 6 the soil is also free from the nodule-forming bacteria; in jar No. 5 the soil contains an abundance of them.

inaccessible or because of their abundant supply of leaves, they drew more food from the air. It was not until late in the last century that the real reason was discovered.

It had been noted that many of the leguminous plants often had peculiar nodules or swellings on their roots which were regarded as harmful to the plant, also that leguminous plants would grow on sandy soils that were too poor to produce erops of ordinary grains. It was 
at last discovered that the ability of leguminous plants to grow under these conditions was connected with the presence of nodules on their roots and that in the absence of such structures, the legumes required as fertile a soil in order to produce a good crop as did any other plant. It was also found that where the nodules did not develop the legume, instead of having a beneficial effect on the soil, left it less fertile, the same as any other plant. It was also found that when the nodules developed on the roots, the beneficial effect was due to the fact that the soil contained more nitrogen after the crop had been removed than before, even though that portion of the crop which was removed contained a considerable amount of nitrogen.

Cause of the nodules. The root hairs of the plant which are exceedingly delicate and unprotected by any thick membrane become infected with the legume bacteria which are in the soil. These cause an increased cell growth at the point of entrance, thus forming the nodule or tubercle which becomes filled with bacterial cells. In some way not well understood, these organisms are able to fix the nitrogen of the soil air and build it up into such a form that the green plant can use it.

Through these discoveries the peculiar effect of the leguminous plants on the fertility of the soil and the ability of the plant to grow in the absence of combined nitrogen was explained. It is evident that the farmer should be certain that any legume he grows should possess an abundance of nodules on the roots so that he will receive the maximum benefit from the crop.

Different kinds of legumes require different kinds of bacteria, as for instance the organisms that normally infect clover have no influence on alfalfa or vice versa. 
In some cases this specific character does not obtain. For example the organisms inhabiting the ordinary sweet clover are able to infect alfalfa but not the common red or white clovers. It is thus necessary to see that the soil contains the right kind of bacteria, and if they are not present naturally in the soil, it must be inoculated with them.

Kinds of legumes. There are many thousands of legumes both wild and cultivated, varying in size from tiny plants to large trees, all of which bear nodules on the roots. In the native flora of every type of soil are to be found representatives of this group of plants. The ordinary beggar-weed, the sensitive plant, and the wild lupines are some of the native legumes. All of the clovers, red, crimson, and white, the sweet clovers, both white and yellow, alfalfa, all of the peas, such as garden, sweet, field, and cowpeas, the various kinds of beans, soy beans, lupines, vetches and serradella, and the pea-nut are among the most important of the cultivated legumes.

The legumes are found growing on all types of soils, in marshy soils, in sand and clay, in those that contain much lime and in those free from it. All types, however, bear nodules, so the bacteria capable of developing under these conditions are wide spread and abundant.

Form and appearance of nodules. The nodules vary in size and appearance depending on the species of plant. Those on the clovers are very small, about the size of a large pin head, and oval in form, with a smooth surface. The alfalfa nodules are much like those of clover but have a tendency to grow in finger-like clusters. The nodules of beans are round, rough on the surface, and much larger than those on clovers, some times reaching the size of a large cherry. The nodules on peas are very 
similar in appearance and size to those found on beans. The size of the nodules depends on the number on the plant. When few, the nodules are likely to be large, when more numerous the size is smaller. The total mass of



Fig. 20.-Tubercles on Soy Beans.

B. the roots are free from tubercles; C. the roots are studded with large tubercles. Large masses of them are to be seen on the main root.

the nodules may make up one fourth of the weight of the root system.

On cutting the nodules open it will be found that the color of those that are small is pale red or pink, unlike the color of any other part of the plant. If a little of the content of the nodule is examined under the micro- 
scope, it will be seen to be filled with innumerable bacteria that move about in the water in which the contents of the nodule has been placed. The nodules are usually found near the top of the root system especially on deeprooted plants like alfalfa, often a large mass of them are found around the top of the tap root. The arrangement is characteristic with some plants like the lupine on which the tubercles grow as bunches on the main root.

Conditions for formation. It has been found that certain conditions are favorable for the production of the nodules. The soil must be well aerated and not acid in reaction. In very rich soils the plant makes use of the same source of nitrogen as do the grains and grasses, the nitrates of the soil, and there is a tendency for the nodules not to develop in such numbers as on a poorer soil where the plant can not obtain sufficient nitrogen from the soil, but in order to make a good growth must get some nitrogen from the air.

Soil inoculation. As was previously stated unless the plant has tubercles on the roots no nitrogen can be fixed and the plant will leave the soil poorer in nitrogen. If the legume is to be a benefit to the soil, the tubercles must be present. While certain of the bacteria are present in every soil, the kind that will form nodules on a new kind of legume may or may not be in the soil. If they are not there, the soil must be inoculated. This can be done most successfully by transferring a little soil from a field on which the particular legume has grown and on the roots of which there were an abundance of nodules. This soil may be broadcasted over the field to be inoculated or the sifted soil may be applied with a drill. Especial precautions should be taken to see that the higher parts of the field are inoculated for these can not 
become infected by surface drainage as can the lower areas.

The disadvantages connected with the use of soil as an inoculating agent, such as the expense, and the introduction of plant diseases, has led to the introduction of pure cultures of the different kinds of nodule-forming bacteria for the inoculation of the soil or the seed. These cultures have been used for many years but have never been as successful as it was hoped they would be. At times the inoculated plants would show an abundance of nodules, again none could be found. This uncertainty of the result makes the use of the pure cultures inadvisable where soil can be procured.

Pure cultures of the legume bacteria are sent out by the U. S. Department of Agriculture; also by a number of the Experiment Stations. These cultures are prepared and sold by a number of commercial laboratories. They are prepared for use in various ways. In some cases the inoculating material is simply added to water and sprinkled on the seed; in others a culture is made by preparing a solution of the necessary food substances which are sent with the pure culture. The usual method of using the cultures is to mix the same with water and to sprinkle the seed with it. The moistened seed is dried in the shade to protect the bacteria from the injurious effect of sunlight and planted as soon as possible.

The inoculation of the soil should be made whenever a new legume is to be grown, when a previous crop has. shown no nodules, or where the nodules were few and seemed to have no effect on the plant. The inoculation need not be made when the same plant has been previously grown on the field and has shown tubercles. With many legumes the seed is likely to be infected with the 
nodule-forming bacteria and even though no inoculation is made some nodules will appear. If the same legume is then grown on the field in a subsequent year, an abundant supply of nodules will be produced as the bacteria will persist in the soil for a number of years.

A large amount of nitrogen is removed from the soil in any leguminous crop but where the nodules are abundant and much nitrogen has been fixed from the air, the soil is left richer than before because the nodules and roots of the legumes are exceedingly rich in nitrogen. As these tissues decay, the nitrogen is changed to a form in which it ean be used by other kinds of plants. In this way the legume has a favorable effect on subsequent crops. The leguminous plants under all circumstances tend to deplete the soil of phosphorous and potassium in the same manner as all other plants.

Effect of nodules on composition of the plant. The presence of the increased nitrogen supply derived from the nodules affects materially the chemical composition of the plant. Plants which have nodules on their roots are found to contain a considerable larger per cent of protein than plants devoid of the nodules. The feeding value of the former is consequently much greater.

Nitrogen fixation by bacteria without the aid of plants. With those forms of bacteria that form the nodules on leguminous plants, no fixation of nitrogen is supposed to take place, except in the nodules of the plant. The bacteria are known to exist in the soil for a number of years even though no leguminous plants are grown on the field. It is thus evident that the bacteria must be able to grow in the soil outside of the plant.

There are found widely distributed in the soil, other 
kinds of bacteria that are able to fix the free nitrogen of the air and build it up into their own protoplasm. They are able to grow in media that contain no nitrogen and must then satisfy their needs from the nitrogen supply of the air. It is supposed that a large part of the nitrogen of the soil has been brought into combination by the action of these bacteria. It has been shown that a soil on which no plants of any kind are growing will increase in its content of nitrogen, and it is believed that it is largely due to these germs. Unlike the nodule-forming bacteria, the fixation of nitrogen by this second class, known as the azotobacter group, can go on independent of the kind of plants that may happen to be growing in the field.

It is important to know the conditions that favor the growth of these nitrogen-fixing bacteria. They are atrobic; hence, grow best in a soil that is thoroughly aerated, stirred and drained. They demand a supply of available potash and phosphorus as well as organic matter from which they derive the energy necessary for the fixation of the nitrogen. In the laboratory the largest amount of nitrogen is fixed in a food medium that contains a sugar such as cane sugar or mannit. In the soil, it is believed that they use the different carbohydrates. contained in the plant residues that are added in the roots of crops, in the green crop plowed under, or in the manure.

In the case of uncultivated land, the greater part of the annual crop falls onto the ground, and undergoes decomposition. The nitrogen-fixing bacteria are thus furnished with suitable food to accomplish the fixation of nitrogen, and the content of the soil in this important 
element slowly increases. On cultivated fields this crop of organic matter is largely removed, so that conditions are not so favorable for the development of this type of life. As a consequence less nitrogen is brought into combination, and a more rapid depletion of the total nitrogen supply of the soil takes place. 


\section{CHAPTER XXIII.}

\section{BACTERIA IN MANURES.}

The waste products of the animal body are elimi. nated largely in the urine and feces. The latter consist. in the main, of the undigested and indigestible parts of the food; the urine contains the waste of all activities of the different tissues of the body. The changes that the food undergoes in the body of the animal, must be looked upon as a part of the complex process by which organic matter is again rendered available to the green plant. The material that is eliminated from the animal is much more easily decomposed by bacterical action than is the food consumed. That which comes from the intestinal tract is already well advanced in the series of changes that occur in the transformation of the organic matter into stable form. It is interesting to know that the work of the bacteria begins in the body of the animal, and that their action on certain parts of the food is of value to the animal, enabling it to make use of parts of the food that without their aid would be impossible.

As previously noted, the alimentary tract of animals is to be considered as one of the natural homes of the bacteria. Food is abundant, while temperature and moisture conditions are favorable for rapid growth. Over one-fourth of the solid matter in human feces consists of bacterial cells. In the feces of the domestic animal, the proportion of bacteria is much less because of the nature of the food. Millions of bacteria exist in every gram of the manure. 
Digestion of cellulose. Coarse fodder, such as hay, straw, or corn fodder contains a large proportion of crude fiber or cellulose. It is known that different kinds of animals can digest this class of substances to a varying extent. In the different digestive juices of the body have been found enzymes that can attack carbohydrates, fats and proteins. None have been discovered that have any action on cellulose. There are in the feces of animals, bacteria that can digest the cellulose, changing it to compounds that can be used by the animal. It is asserted that ruminating animals can digest 75 per cent of the eellulose in their food, and the horse 50 per cent. Dogs: and the strictly carnivorous animals cannot utilize this material at all. In the case of the ruminating animals the food remains in the body for a long time, as for instance, in the cow for six or seven days, and with sheep possibly a still longer time. There is thus opportunity for extended bacterial action in such a favorable environment. In man the food passes through the body in a much shorter time, and there is not the opportunity for the bacteria to attack the cellulose.

It is very probable that the bacteria of the intestinal tract are necessary to the well-being of all kinds of animals. At the time of birth, the intestines are free from bacteria but within a short time, less than a day, the bacteria have invaded the entire tract. Definite kinds of bacteria are found to occur. When these are replaced by other forms, the animal is quite likely to suffer.

Composition of barnyard manure. Manure is made up of the solid and liquid excreta of the different kinds: of animals kept on the farm and of the litter used in the stables. It thus contains all of the compounds found in the plant, and will undergo, in the main', the same set of 
changes that the plant tissue does in the soil. As has been previously stated, it is of the greatest advantage to the farmer to return to the soil as large a part of the material removed in the erop as possible. This is true not only for the mineral ingredients of the soil, as potassium and phosphorus, but also for the organic matter. The problem of the farmer is to handle all manures made on the farm in such a way that the least loss may occur.

Decomposition of manure. Manure when placed in piles rapidly decomposes under the action of micro-organisms, continuing as it were, the changes inaugurated in the intestinal tract. The bacteria voided with the excreta serve to inoculate the bedding or litter used. The bacteria decompose the organic matter with the result that in a well-rotted manure, but little trace of the material used as bedding can be found.

Nitrogenous compounds. Stable manure contains various nitrogen-containing compounds that are found in the plant. These undergo a process of ammonification, due to the action of the same kinds of bacteria that are responsible for similar changes in the soil. A part of the nitrogen that is used in the cell processes of the animal is eliminated in the urine in the form of urea, uric acid, and hippuric acid. These substances are converted into ammonia salts. In the summer the odor of ammonia is often noticeable in horse manure, due to the decomposition of the nitrogenous compounds in the urine. The ammonification of the nitrogen in the solid manure and in the litter is less rapid. As ammonia is readily soluble and is also volatile, it follows that where fermentation is rapid much of this valuable fertilizing ingredient is lost in the leachings from the pile or passes off into the air. 
Much of this loss can be prevented by the use of proper methods which will be described later.

In the manure heap the ammonia is not changed into nitrates as it is in the soil for the conditions are not favorable for the nitrifying bacteria. Organic matter is too abundant and oxygen is also lacking except in the outer layers of the pile. If the manure is allowed to stand, especially if it has been mixed with earth, until it is completely decomposed, a small amount of nitrate will be found. Since no nitrates are formed, denitrification cannot take place.

Cellulose decomposition. The decomposition of the cellulose begun in the animal is continued in the manure pile by the same kind of bacteria as in the body of the animal. The starches and sugars, etc., are also readily fermented by micro-organisms, and carbon dioxide, water, hydrogen, and organic acids are formed.

Losses from manure. It is impossible to return to the soil all of the organic matter removed in the crop, even though the entire crop is fed to farm animals and the manure carefully handled. In the respiration of animals a large amount of carbon is eliminated from the body; this was taken in with the food. Oxygen and hydrogen in the form of water are given off as respiratory products and in the perspiration. The nitrogen and mineral ingredients are eliminated in the same amounts as are contained in the food consumed, except for the quantity retained in the tissues of the animal. This is of course much more, in the case of a growing than a mature animal.

In the decomposition processes in the manure pile, the organic matter is destroyed, which is in itself a loss to the soil, since if applied to the land, it would have fur- 
nished food for bacteria, especially the nitrogen-fixing ones, and have added to the humus content of the soil. It is now realized that the value of manure is not determined alone by the amount of potassium, phosphorus, and nitrogen it contains, but the organic matter itself exerts a most important effect. Market gardeners find it advantageous to pay more for manure than the fertilizing ingredients alone would cost in the form of commercial fertilizers. For most soils the greater the amount of organic matter that can be returned the better for the soil. The practice of hauling manure directly to the field from the stable is probably the most successful means of conserving its value.

If very large amounts of manure are to be applied, as in market gardening, unrotted manure cannot be used on account of its injurious effect on the crop. The amounts usually applied in farm practice have no injurious effect.

The potassium and phosphorus of the manure are changed to soluble form in the decomposition processes. These can be lost from the manure only through the leaching of the pile. The largest loss is liable to occur in the case of nitrogen when ammonia is freely formed. In order to prevent the loss in the latter form, materials such as gypsum, kainit, sulphuric acid, and peat, that were supposed to fix the ammonia, were formerly employed. It is now recognized that the loss prevented by their use is very small, and they are no longer used to any extent.

Hot and cold manures. Horse and sheep manures are called hot manures because if placed in a pile they heat or fire fang. Cow and hog manure are cold manures. During their decomposition enough heat is evolved to keep them from freezing in quite severe 
weather, but they never fire fang. This difference is primarily due to the physical condition of the manure and to its water content. The horse manure is dry and open, allowing the air to penetrate into the pile, while cow manure, even when large amounts of bedding are used, is of such a physical texture that air cannot enter. 'The large amount of air in the horse manure permits the growth of aerobic bacteria and molds. The heat evolved by their respiration is great and the decomposition they produce very complete. The organic matter is practically burned, the carbon, hydrogen, and nitrogen passing into the air. Where decomposition occurs under anaerobic conditions the process is much slower and less complete. If a pile of horse manure is well packed, so as to exclude the air, the usual aerobic fermentation will not occur, but will be supplanted by anaerobic action. In such a case the loss of nitrogen and organic matter will be much less.

In handling any manure, the activity of aerobic organisms should be excluded as far as possible by piling the manure in large compact piles of considerable depth. If the manure is allowed to accumulate in the stalls or feeding sheds in which the animals run loose, the loss will be reduced to the minimum, since the constant tramping of the animals excludes the air, and the manure is protected from leaching.

If the manure is hauled directly to the field from the stall the decomposition goes on to some extent on the surface, but the soluble products formed pass into the soil. There may be some loss of nitrogen as ammonia, but it is certain that the losses are much smaller than when the manure is allowed to rot in piles. If it is not possible to apply it directly, the piles should be thoroughly packed 
and, if under cover, should be kept moist. The average difference in temperature between a loose pile of cow manure from which the water was allowed to drain, and ene placed in a tight concrete pit and well packed, was $98^{\circ} \mathrm{F}$. for one month after the manures were placed in the pits. Heat in the manure pile indicates a combustion of organic matter as much as in a furnace. The loss from the loose pile amounted to 53 per cent of the organic matter and 34 per cent of the nitrogen; in the compacted pile the losses were 28 and 15 per cent respectively. 


\section{CHAPTER XXIV.}

\section{WATER SUPPLY AND SEWAGE DISPOSAL.}

An abundant supply of pure and healthful water is one of the necessities of modern life, whether in the city or on the farm. In the city, the home is provided with this necessity through the action of the municipality; the individual citizen does not have to concern himself with the question as to the source and quality of the water suppiied, while on the farm the problem of obtaining a plentiful supply of water fitted for household purposes is an individual one, and one that is frequently neglected, although it means so much to the comfort and health of the farm home.

Modern cities are spending immense sums of money in securing safe and adequate water supplies and in pro. tecting them from pollution. The farmer should use the same foresight and the cost for supplying the farm home with good water will be no greater than must be paid by the home in the city.

Relation of water to disease. A number of transmissible diseases may be carried from one person to another through the medium of the drinking water. The most important of these are typhoid fever and cholera. The former, a world-wide disease, the latter one that is not found at present in America and Western Europe. The reason these diseases are often spread by means of water is to be found in the fact that the bacteria are given off from the body in the urine and feces and as great care- 
lessness often prevails in the matter of disposal of household sewage, the water supply becomes contaminated. The sewage of a city may be discharged into a river, from which another city a few miles further down draws its water for household use. A city may discharge its sewage into a lake and from the same source draw its water supply, as is the ease with nearly all the cities on the Great Lakes. Under such conditions more or less of the sewage is certain to enter the water mains. As stated in the discussion on the relation of milk to transmissible diseases, there are people who have recovered from typhoid fever and who continue to harbor in and give off from their bodies the disease-producing organisms. These people are supposed to be the means by which the disease maintains its presence in the community, no matter how much care may be used in the disinfection of the discharges of persons known to be suffering from typhoid fever. Cities now realize that it is economy for them to protect themselves by securing their water supply from sources known to be free from pollution with sewage, or through purification by the proper filtration of water from suspected sources.

The farm home should likewise be insured against typhoid fever through the protection of its water supply from sewage pollution. It is frequently thought that. typhoid fever is an urban disease, but as a matter of fact it is more prevalent in the country. The city home is exposed to infection by means of the water from many other homes in which typhoid may be present, while the farm home is not related in so direct a manner with other places in which the disease may be present. There, are, however, abundant ways in which the disease may be brought on to the farm. 
Relation of water to soil. As was previously stated the upper layers of the soil are rich in germ life. The drainage water from such places will be teeming with bacteria. The shallow dug well, loosely bricked up, is filled during the wet seasons with water coming from the upper layers of the soil. If material containing diseaseproducing bacteria is placed on the ground near the well, as in a privy vault, the bacteria may be carried by the pereolating water into the well. The distance between the vault and the well that is required to prevent pollu-

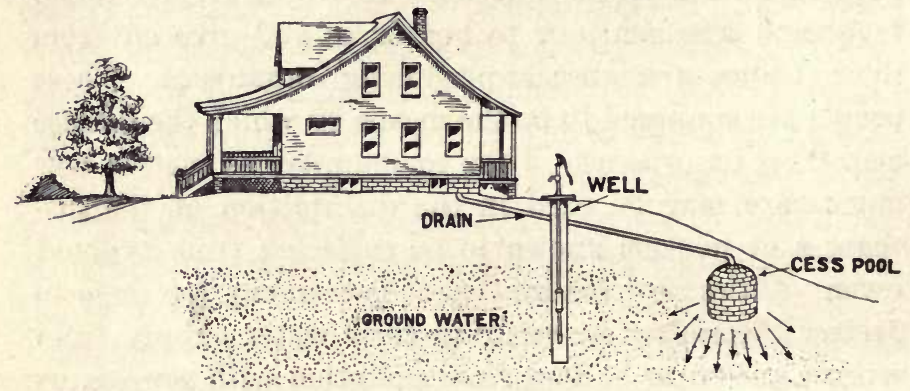

Fig. 21.-Pollution of A Weil.

The well water may be polluted from a cess pool or vault by the percolation of the ground water into the well. (After Harrington.)

tion of the well can not be stated in definite terms as it will depend on the nature of the soil, whether it is elose and dense as in a clay soil, whether it is porous, as a sandy soil, or whether the percolating water may form channels in it, as in lime stone. The distance that may be traversed by bacteria in the underground water also depends on the slope of the underlying rocks. A well on higher ground than a privy is not necessarily protected from pollution. 
As the water percolates through the soil, the bacteria are removed until at a varying depth beneath the surface no organisms are found. The water that enters a well from the lower layers of the soil may be free from bac. teria. Such a supply is the most desirable if it can be pumped from the well in the same condition as when it entered. In order to obtain the water in this condition, the well must be protected from all surface drainage. It is very difficult to obtain this condition except in the case of a drilled well which is cased with a threaded iror pipe, and which is protected at the top so that no water can enter the casing. A dug well, even if provided with a tight wall to a considerable depth, is likely to receive more or less surface water and hence is liable to pollution.

The well should be so arranged at the surface that no surface water, or water that is pumped onto the curb can enter the well, for material containing disease-producing hacteria may be brought on to the curb and in this way pollute the water. The dug well, so common in the older sections of the country, is a menace and should be replaced by the safer drilled well. The old-fashioned well with bucket and sweep, which is so often regarded with sentiment, is the most dangerous type of well, even though the water is clear and sparkling.

The water of a well that receives surface drainage is not harmful at all times, but it may become so at any time. The conditions needed to produce disease are all present except one, viz, the deposition of material that contains disease-producing bacteria within the zone from which the water percolates into the well. This essential condition may not be present for years, but at last it is 
introduced and an outbreak of typhoid fever occurs in the family.

On the diary farm, as previously mentioned, an opportunity is offered for the farther spread of the disease by means of the milk infected from the water or in some other way. The wise course to follow is to supply tho home with water that is so protected that it cannot be the cause of disease, even if material containing typhoid bacteria is deposited near the well. This demands a well into which no water can enter except that which has percolated through a sufficient bed of soil to insure its freedom from all harmful bacteria. This demands again the positive exclusion of water from the upper layers of the soil by the use of a non-porous wall, preferably an iron pipe, and the protection of the well at the surface.

Springs are the outlet of under-ground streams. Spring water is free from bacteria as it flows from the ground and is, of course, an excellent water for household use, but there is often danger of surface pollution entering the basin of the spring, unless it is carefully protected.

The first consideration in obtaining water for the home should be to secure a safe supply that is thoroughly protected from all possible pollution with disease-producing bacteria. An adequate supply is also a consideration of great importance in order that the farm home may be provided with the modern conveniences. These so-called "modern conveniences" such as water carriage for disposal of sewage, drinking water under pressure and also hot and cold water supplies for lavatory, laundry, and bath have been regarded as obtainable only in the city, and yet all of these sanitary arrangements are readily secured if an adequate water supply is available. 
Sewage disposal. The disposal of house sewage by water carriage is not only a matter of great convenience but a hygienic necessity. Through the use of the ordinary open vault there is not only opportunity for the pollution of the well water but the disease-producing bacteria may be carried from the privy vault to the kitchen, the milk room, and elsewhere by means of the common house fly. If the sewage can be disposed of in a convenient way and yet avoid the danger of pollution of water and food much will be done for the comfort and health of the home.

Cities that are located on a body of water often discharge their sewage into the river or lake. Others less favorably located find it necessary to dispose of the wastes in other ways, utilizing different methods of purification that shall render the sewage comparatively harmless. Most of these methods of purification depend on the work of bacteria. The sewage contains organic matter of various kinds, which will be decomposed in the same manner as has been shown to occur in the soil. The final products will be harmless, and in the process of decomposition the disease-producing bacteria will be destroyed.

The methods of sewage purification seek to establish conditions favorable: (1) for the growth of anaerobic bacteria that shall render soluble all solid matter contained in the sewage just as the solids are made soluble in the soil; (2) for the development of the aerobic bacteria that shall complete the work of decomposition, and the nitrifying bacteria that change the ammonia to nitric acid. Modifications of the types of plants used by cities in the disposal of large quantities of sewage ean be used on the farm for the safe and convenient disposal of the 
house wastes. The cost of such a plant need not be more than the eity home must pay toward the construction of the sewers of the city.

The conditions that exist on the farms differ so greatly that it is impossible to give a detailed description of a disposal plant that will answer the needs of all farms. In the following description, the essential conditions that must be established in order to have a successful plant will be given.

The house should be provided with a pressure tank, either in the elevated form, or one in which the pressure is maintained by compressed air, so that flushing arrangements can be used in the water closets.

Septic tanks. The sewage passes from the house drain into a tank in which it is allowed to remain for several days. The tank can best be made of concrete. It should be placed beneath the ground so as to avoid freezing. It should be large enough to hold the accumulations of several days, since it is necessary that time be given for the bacteria to decompose the solid matter. A period of four days is sufficient, although a longer time will have advantages. The amount of household sewage will not exceed a barrel per day per person on the average farm. Thus a tank holding thirty to forty barrels will suffice for a family of six persons.

The sewage as it passes into the septic tank contains much organic matter in solution and is in condition to serve as bacterial food. The solid matter of the sewage sinks to the bottom of the tank and is rendered soluble by the continued bacterial action. On the surface of the sewage a scum collects which shuts out all air and gives favorable conditions for the growth of anaerobic bacteria. The sewage as it flows from the tank after four or five 
days exposure is a turbid liquid with a disagreeable odor. The bacterial action is so complete that the solid organic matter is wholly destroyed and scarcely any sediment collects in the tank; hence it need be emptied and cleaned only at intervals of several years. The tank must be so arranged that a quantity of sewage can be discharged from it at intervals rather than constantly as is the case with the sewage flowing into the tank.

The sewage should remain in the tank for a sufficient length of time so that it will no longer putrefy. If this is accomplished, the farther steps in purification and disposal can often be very simple. If the septic tank is so situated that a drain ean be laid which shall discharge onto the surface of a field that has some fall at a distance from the house, the sewage can be discharged onto the surface of the soil. Since the sewage contains no solid matter it sinks rapidly into the soil, where the purification is completed. This arrangement can best be used on a sandy or loose soil. The drain should empty into open furrows. Since the tank is arranged so that the sewage ean be discharged at intervals the soil has an opportunity to become aerated between the periods of discharge. This avoids keeping the soil saturated with moisture which of course would be detrimental to nitrification. A preferable process is to discharge the sewage from the tank into drains of ordinary tile laid with open joints. The sewage as it flows from the tank at intervals. fills the tile and gradually percolates into the soil through the open joints. On account of the intermittent discharge it has time to drain away and thus favorable conditions for nitrification are maintained. If the sewage flows into the drains constantly, it would all seep out through the first few joints and keep the soil water- 
logged. With the discharge at intervals, the entire line of tile is filled and no part of the soil is kept in a saturated condition.

The tiles should be laid 18-24 inches below the surface, the trench about the tile should be filled with cinders or gravel so that the water may pass out of the tiles freely. It is not necessary to place the tile below the frost line, although they will be somewhat disintegrated by freezing and the system will have to be dug up more frequently than if freezing did not occur. If the tile are laid too deeply, the amount of oxygen is small and nitrification is retarded. In a loose, sandy soil, the tile can be laid deeper than in a dense soil and a much shorter line of tile will suffice. By increasing the length of the tile drains, the system will work in a satisfactory manner in a close clay soil. The tile can be laid beneath a cultivated field or beneath the lawn since they need be removed and cleaned only at intervals of several years.

The essential parts of the system are: (1) a supply of water for the flushing of closets, etc.; (2) the house so situated that a small amount of fall can be had away from it in order that the septic tank can be emptied into the drains; (3) a septic tank large enough to hold the quantity of sewage produced in three or four days so that ample time can be given for decomposition of the solid matter; (4) a method of discharging a quantity of sewage at intervals.

In the accompanying figure the general arrangement of a sewage disposal plant is given. The main drain enters the septic tank below the surface of the liquid so as to avoid disturbing the scum on the surface or the sediment. The first compartment, the septic tank proper, should hold at least three days sewage and is separated from the 
second compartment by a partition that does not reach the top of the tank. When the first compartment is filled, the sewage runs over the top of the partition and gradually fills the second compartment. In order to prevent the scum from passing into the second compartment a baffle board is bolted to the partition in such a manner that its top is above the level of the scum while its bottom dips into the liquid. Some space is left between the baffle board and the partition.

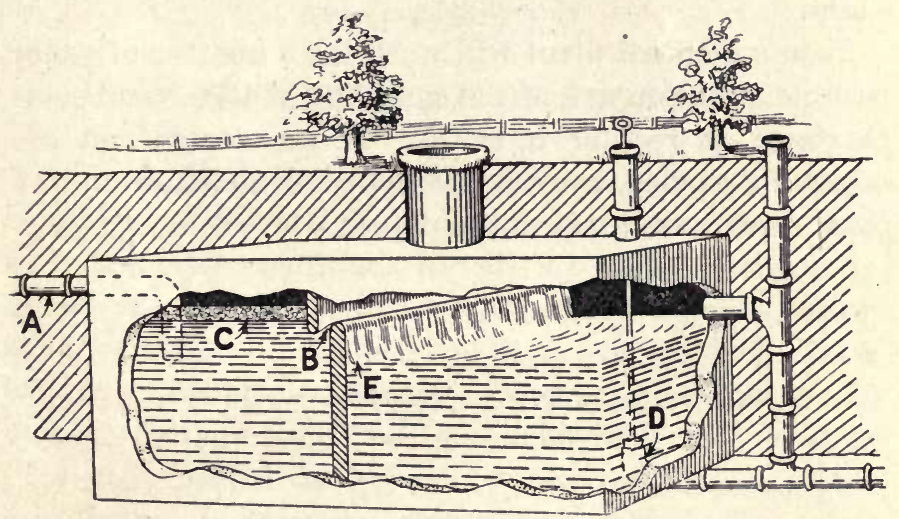

Fia. 22.-A Septic Taxk.

A. drain from the house; B. baffle board to keep the scum (C) from passing into the second compartment; D. plug closing the entrance to the drain.

At any desired time the second compartment is emptied by pulling the plug which closes the opening of the drain. The entire contents of the chamber is discharged into the drain at once. The plug should fit tightly so as to prevent constant leaking of sewage into the drains. The second compartment should be of about the same capacity as the first. An overflow pipe is provided so that if the second compartment becomes full, the tank 
will not be flooded. The opening of the overflow should extend to the surface and be protected by a screen, thus. allowing air to pass in and out of the drains.

The two compartments can be made of different depths if desired. The first can be increased in capacity by increasing its depth; this also serves to aid in maintaining a constant temperature in the sewage. The second division can be of less depth, thus aiding in obtaining the necessary fall where the slope of the ground is slight.

Such a disposal plant will work for a number of years. with no attention except the emptying of the second compartment at regular intervals. If the drains run beneath the garden, a constant supply of moisture and of plant food is supplied to the plants. 


\section{SECTION $\nabla$.}

\section{FOOD PRESERVATION AND DISEASES OF PLANTS.}

\section{CHAPTER XXV. \\ PRESERVATION OF FOODS.}

All organic matter whether of plant or animal origin is subject to the attacks of living organisms which find in it favorable conditions for growth. The changes induced are, in the main, decomposition changes which usually render the material unfit for use as food either by human beings or animals. Food supplies that are to be kept for any length of time must be treated so as to prevent or retard the growth of micro-organisms. This can be done in a variety of ways.

Drying. One of the most common ways of preserving organic matter is to dry it, so that the water content is reduced to a point where growth of micro-organisms in or on the material is impossible. The bacteria can grow only in the presence of considerable amounts of moisture. Molds demand much less moisture for their growth, hence many things may be protected from bacterial action and still be spoiled by the growth of molds.

Fodders of all kinds are dried in the field before placing in the barn. If hay or dried forage is not thoroughly dried, it will heat in the mow. The heat is produced by 
the action of organisms, such as the molds, the same as are concerned in the heating of manures. Ear corn, placed in the crib before it is well dried may likewise mold, although the moisture content is too low to allow growth of bacteria. Various ground-feeds, as meal, readily mold if kept in a damp place. Wheat becomes musty when damp. All of these troubles are caused by the presence of sufficient moisture to allow of mold growth.

The preservation of many foods is also made possible by drying, as apples and other fruits, berries, green corn, etc. Meat is also protected from putrefaction in this way. As previously stated, the muscles of a healthy animal are free from bacteria; but in cutting up the carcass the meat becomes contaminated with bacteria and consequently undergoes decomposition. If, however, the meat is placed in a dry atmosphere, the outer surface soon becomes so dry as to prevent the growth of bacteria, and as the moist inner part remains free from organisms it does not decompose. If the drying is continued until the entire piece is firm, it will keep for an indefinite period. In South America dried meat is extensively prepared and is shipped to all parts of the world. When ground and mixed with fat it is a very concentrated form of food and is used where fresh meat can not be procured.

Dried milk, or milk powder, and dried eggs are articles of commerce and are extensively used in place of the fresh materials, especially by bakers.

The drying of foods usually injures their flavor materially, consequently preservation by desiccation is being replaced, wherever possible, by other methods that conserve the natural flavor to a greater degree. 
Salting. If certain substances like salt are added to organic matter, they tend to preserve it. Most kinds of bacteria are unable to grow in a saturated solution of common salt. This fact is made use of in the preservation of pork and corned beef, where the meat is placed in a strong brine. If the brine is too weak, certain of the bacteria will grow and the meat will spoil. Such a condition is more apt to obtain during warm, than during cold weather. The effect of low temperature, which has a restraining influence on bacterial action, together with the inhibitory action of the salt, exert a more pronounced preservative effect than either of the preservative agents alone. Salt may be applied in a dry form as in the preservation of hides and meats.

Smoking. In the preservation of meats such as hams and bacon by smoking, another factor is operative. In the slow combustion of wood, antiseptic compounds belonging to the cresote group are formed. These are deposited on the surface of the meat and are absorbed, and together with the salt protect the meat from the action of the bacteria on its surface

Preservative action of sugar. Sugar, although furnishing an ideal food medium for bacteria and molds. may exert a preservative action such as is shown in syrups. All solutions containing sugar, as molasses, eane and maple syrups, or fruits conserved in sugar, will not keep unless they are sufficiently concentrated. Where they undergo a fermentative change they are said to have "worked." The preservative action of sugar in concentrated solutions depends upon the extraction of water from the bacterial cells causing them to become flaccid or wilted. Under such conditions growth can no longer go on and fermentative action ean not follow. 
Sweetened condensed milk is an illustration of this method of preservation. Part of the water of the milk is evaporated by heating in a vacuum, thereby increasing the density of the milk. The addition of sugar is then made which still further increases the density to a point where bacterial growth is impossible. Such milk may contain living organisms. Dilution of the milk with several volumes of sterile water reduces the concentration to a point where bacterial growth becomes possible and the milk then undergoes fermentation.

Fruits are protected from decomposition by placing them in concentrated sugar solutions in the making of preserves. In the preparation, the fruit is cooked so slightly in the sugar that it is not rendered sterile, but the bacteria that are not destroyed are unable to grow in the concentrated medium. Marmalades, jams, and jellies owe their keeping qualities to the same factors.

Preservative action of acids. The bacteria are unable, as a rule, to grow in a strongly acid medium. This fact is made use of in the preservation of many foods and even fodders. One of the most common uses of acids in the preservation of foods is in the preparation of pickles with the use of vinegar, which is itself a product of bacterial action. The acid reaction of the vinegar is so strong that the ordinary bacteria can not grow in it, thus if certain vegetables, as cucumbers, are placed in the vinegar they will be protected against the attacks of bacteria. Some of the molds find favorable conditions for growth in vinegar, and may destroy so much of the acid of the vinegar as to allow the bacteria present to grow with the result that the pickles are spoiled. Frequently spices are added to the vinegar to be used for pickles, since they improve the flavor. They also have a preser- 
vative effect which is made use of in the preparation of such foods as mince-meat, sausage, etc. In the first, the preservative effect is aided by the sugar present and in the case of sausage by the salt.

Fodders such as corn, clover, and other leguminous plants may be preserved by placing them under such conditions that the air can not reach them, as in a silo. In such cases the preservation is accomplished by virtue of the acid which is formed in the tissues as a result of the continued action of the plant cells in the absence of air.

The material to be ensiled must have the plant cells in an active condition. Silage can not be made from ripe or frozen corn. In the ensiling of clover it is necessary to place it in the silo before much wilting of the plants has occurred.

The living plant cells continue to respire after they are placed in the silo. The supply of free oxygen is soon exhausted and the interspaces filled with nitrogen and the carbon dioxide formed by the respiring plant cells. The cells in their effort to keep alive draw on the oxygen that is found in the sugars and starches of their contents. They are then acting exactly as the anaerobic bacteria when they obtain their supply of oxygen from the sugar in the culture medium. In the effort of the plant cells to obtain oxygen from the materials of the cells, they decompose the sugar with the formation of lactic and acetic acids and carbon dioxide. These acids are formed in such amounts as to prevent all bacterial growth. The silage of course contains many bacteria that were present on the fodder ensiled, which continue to exist in the silage but are unable to grow. The mold spores are also present in the silage but they are likewise unable to grow. 
on account of the lack of free oxygen. The carbon diox-ide that is formed in the silage is heavier than the air and does not pass out of the silage, hence, there is no opportunity for the oxygen to enter from the surface. It the silo is not perfectly tight at the bottom and on the sides, the air will penetrate for some distance, and allow the molds to develop and cause the silage to spoil. If the silage is removed from the silo and placed in a loose pile, the molds at once begin to grow because of the abundant supply of oxygen, thus furnished.

The plant cells in their respiration produce heat just as the animal does in its breathing. In the case of the living plant, the heat passes off as rapidly as formed. In the mass of material in the silo, the heat produced can not be radiated as rapidly on account of the volume, hence, the temperature of the silage rises to $120^{\circ} \mathrm{F}$. or above. This high temperature is retained for a long time and prevents the freezing of the silage, a very fortunate circumstance without which it would be very difficult to use this method of preserving fodder in the north.

If the plant cells are dead because the plant is ripe, or because of being frozen, the oxygen of the air in the silage is not used, and molds are able to grow. Acids are not formed by the decomposition of the sugars and consequently various kinds of bacteria are also able to grow. The result is a rotten mass instead of a fermented, but succulent and nutritious feed. It is desirable to allow the corn to become well matured, as the silage formed is not as acid as is that prepared from the more immature corn. This is due in part to the difference in the composition of the plant at different stages. If the corn or clover is somewhat wilted, the cells cannot respire even though they are not dead. If water is added to the silage 
as it is placed in the silo, the cells are revived and normal silage is formed, when without the addition of water the silage would spoil.

In the preparation of sauerkraut the fresh tissue is treated in very much the same way as is that placed in a silo, except that salt is added and the cabbage is packed until the interspaces are filled with liquid instead of gases as in silage. In this weak brine, acid-producing bacteria grow, apparently forming from the sugar and starches of the cabbage, lactic and acetic acids, that prevent the growth of the putrefactive bacteria. Sauerkraut is usually stored in open vessels. On the surface of the acid liquid, molds grow which gradually neutralize the acid. At last a point is reached where the putrefactive bacteria can begin to grow. The sauerkraut then changes into an offensive mass of decomposing tissue.

Preservation by canning. In many of the processes of food preservation, the product is less appetizing than the fresh material. In order to avoid this as far as possible, the process of preservation by canning has been introduced. In the canning of most materials the bacteria are absolutely destroyed by heating where the exposure is made either at the boiling point of water for a considerable period or for a shorter period of exposure at higher temperatures. In the canning of corn, peas, meats, fish, etc., the latter process is employed. The canned foods are sterile and will keep for an indefinite period. In the canning of very acid vegetables, as tomatoes, it is not necessary to render them perfectly free from living bacteria, as the acid prevents germ growth. If the heating is sufficient to kill the mold spores, yeasts, and bacteria that do not form spores, the tomatoes will keep. Some bacterial spores will be left but they can not: 
germinate on account of the acid reaction of the tomatoes. Corn, peas and nonacid vegetables must be made absolutely free from all organisms. This is often quite a difficult process in the household, hence these are handled with less success than are the acid vegetables like tomatoes.

Preservation by cold. In the modern methods of food preservation, low temperatures are constantly employed. All kinds of foods are placed in cold storage. If the temperature is above the freezing point as must be used with certain kinds of foods, the bacteria grow slowly. If the material is such that the temperature can be reduced below the freezing point, the growth of bacteria will be prevented. Butter and meats are stored at temperatures far below the freezing point. Eggs and fruits must be kept above freezing.

Preservation of eggs. Fresh eggs soon deteriorate in quality due to the growth of organisms that cause the egg to spoil. Infection of the egg may occur in the oviduct of the hen before the shell is developed. Also, owing to the porous nature of the shell, bacteria may work their way through it into the white of the egg which affords them an excellent food medium. A number of methods have been devised whereby the keeping qualities may be enhanced. These methods are of much practical value as they enable the surplus eggs of summer to be held and disposed of at more profitable prices in winter when fresh eggs are scarce.

The first step in all processes of preservation should be to keep the eggs clean by maintaining clean straw or other material in the nests. The most successful way of keeping the eggs is by placing them in a solution of water glass (sodium silicate). This compound can be procured 
at many drug stores. It costs from one dollar to one dollar and a quarter per gallon. The preserving solution is prepared by adding to nine parts of water that has been boiled and allowed to cool, one part of the water glass mixing the solution thoroughly. The eggs should be placed in the solution within twenty-four hours after they are laid. It is claimed that April, May and June eggs keep better than do those laid later in the summer. It is advisable to use July and August eggs first when eggs from all of the months have been preserved. The eggs should be examined before placing them in the solution to see that they are clean and are not cracked. The storage room should not be above $60^{\circ} \mathrm{F}$. and should be as uniform in temperature as possible.

Preparation of vinegar. Fruit juices, as apple juice, undergo a spontaneous fermentation. There are present on the surface of the fruit, yeasts which find favorable conditions for growth in the juice. These change the sugar to alcohol as in the preparation of cider and wine. If these liquids are allowed to stand exposed to the air, they usually undergo, spontaneously, what is known as the acetic fermentation in which, by the action of the acetic acid bacteria, the alcohol is changed to acetic acid. The bacteria causing this change are aerobic and grow only on the surface of the liquid. It is therefore advisable to have the cask only partially filled with the liquid.

The acetic bacteria grow most rapidly at $70^{\circ} \mathrm{F}$. It requires a number of months (12-18) to complete the process of acetification. The process may be hastened somewhat by adding to the cider or wine a quantity of motherof-vinegar which is simply a mass of acetic acid bacteria. After the process is completed the casks of vinegar should be completely filled and stoppered tightly in order to pre- 
vent the growth of aerobic bacteria that destroy the acetic acid and thus weaken the vinegar.

A more rapid process is known as the Orleans process, in which dilute solutions of alcohol are allowed to trickle over beech wood shavings. This brings the liquid in intimate contact with the air and after the shavings once become seeded with proper bacterial growth, the conversion of the alcohol solution to acetic acid occurs very rapidly. 


\section{CHAPTER XXVI.}

\section{BACTERIAL DISEASES OF PLANTS.}

Bacteria, as a rule, grow best in food substances that are alkaline in reaction, while other fungus plants, molds, rusts, and mildews, find most favorable conditions in an acid medium. The juices of the animal body are alkaline, those of plants are usually acid. These facts have been usually regarded as the explanation of the greater susceptibility of plants to diseases caused by fungi other than the bacteria. Very few important diseases of animals are produced by molds, and, conversely, few bac. terial diseases of plants are of great economic importance. Another reason for the greater prevalence of bacterial diseases in animals is that the invasion of the animal body by bacteria is made possible through the natural openings of the body. The invasion of the plant tissue is more difficult since there are no natural openings comparable to. those of the animal body.

The diseases of plants caused by rusts, mildews, smuts. etc., are of the most varied nature and affect all kinds of plants. Methods of prevention through the use of solu. tions applied to the seed as in the treatment of oats and barley with formaldehyde or hot water in order to destroy the smut spores on the grain, or the spraying of fruit trees to destroy the fungi thereon, are widely and successfully used.

A number of bacterial diseases of plants have been studied. The knowledge concerning many of them is: 
incomplete and methods of prevention can, therefore, not be so successfully used as in the case of diseases caused by other fungi.

Pear blight. A disease that is most common in the pear is known as blight, or fire blight, since the diseased parts appear as though they had been injured by fire. The disease affects apple, quince, apricot, and plum trees. It is said to affect the mountain ash and several species of hawthorne. The bacteria enter the tissue most

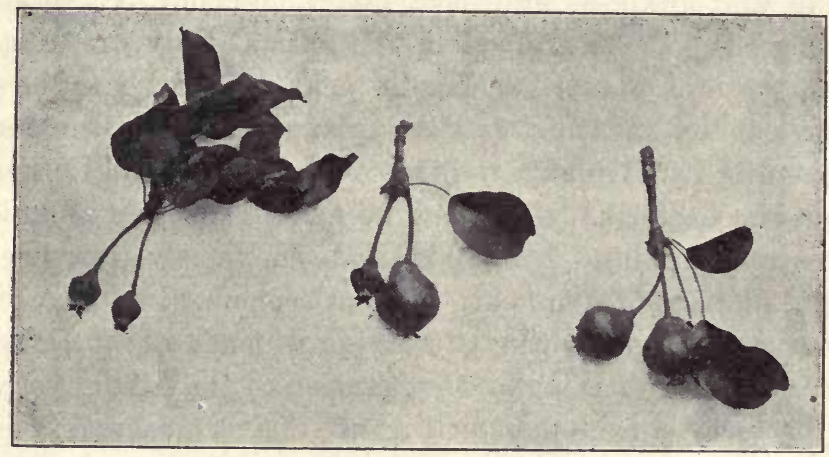

Fig. 23.-Pear Blight.

The bacteria causing the shriveling of the fruit enter through the blossom.

often through the blossom, being carried from flower to flower by bees and other insects. They may also enter through wounds on any part of the tree. The bacteria grow in the inner bark, gradually working their way down the twig, causing the leaves to turn brown and to become dry, and the bark to blacken and shrivel. The growth may extend to the trunk and the tree be destroyed.

The growth of the bacteria in the tree is most rapid in the spring and summer while the new tissues are tender 
and full of sap. By midsummer the progress of the disease is checked by natural causes. The bacteria may pass the winter in the affected tree and with the advent of warm weather begin to grow once more. It is claimed that trees in a thrifty condition and that are making a large amount of growth are more susceptible to attacks than trees under less favorable conditions.

Prevention. Since the bacteria are protected by the bark nothing can be done to destroy them by the use of spraying solutions. The only method of preventing the spread in the tree is by the removal of all affected branches which should be cut off several inches below the last visible signs of disease as the bacteria extend beyond this point. The diseased wood should be burnee, otherwise the bacteria may be carried to still healthy trees by insects. Care should also be exercised not to spread the disease through the pruning or grafting knife.

Cabbage rot. The cruciferous plants as cabbage, cauliflower, turnips, etc., are subject to rots caused by bacteria. The most common method of infection of the plant is through the small water pores on the edge of the leaf. They may also enter through wounds such as are made on the roots at the time of transplanting. It has been shown that the seed may be infected; in this way the soil of the seed bed is inoculated with the bacteria and opportunity is offered for infection of the young plants. The bacteria will persist in the soil of a field or seed bed for a number of years, hence it is advisable not to use the same field or bed when the disease has appeared. Seed may be rendered free from the cabbage rot bacteria by soaking it in a one to one thousand solution of corrosive sublimate for fifteen minutes.

The disease appears first in the form of brown spots on 
the edges of the leaves. The spread of the disease in the plant is along the veins and ribs to the main stem. On cutting across the stem of an infected leaf one can see the blackened ends of the fibrous strands (fibro vascular bundles). The channels that carry the food and water supply of the leaf are destroyed; the leaf is thus deprived of nourishment and dies.

Efforts to combat the disease in the field by the removal of diseased leaves have proved unsuccessful. Preventive measures must be confined to a treatment of the seed and to the growing of cabbage in a system of rotation rather than on the same field continuously.

Melon wilt. Squash, cucumber, and melon vines are subject to a bacterial disease known as wilt since the affected tissues are wilted, due to the plugging of the water tubes with the bacteria. The disease is most prevalent in the early summer and is easily told from all other troubles of the melon family by the sudden wilting of the leaves without any other visible symptoms.

The bacteria live in the soil and gain entrance to the plant through wounds. It is undoubtedly spread from plant to plant by means of the various insects that feed upon the vines. The only means of prevention is to grow melons and squash in rotation with other crops. 


\section{INDEX.}

Abortion, contagious, 147 .

Acids, preservation of foods by, 228.

Acidity produced in milk, 54 .

Actinomycosis, 142.

Aeration of milk, 48.

Aerobic bacteria, 8 .

Air, bacteria in, 14; contamination of milk from, 33 .

Alcoholic fermentation of milk, 60.

Ammonification, 187.

Anaerobic bacteria, 8 .

Anthrax, 98; spread of, 103; vaccination against, 101.

Antiseptics, 12; in milk, 48.

Antitoxin for tetanus, 132.

Azotobacter, 205.

Bacteria, aid in animal digestion, 208; colonies of, 18; determination of number of, 17; distribution of, 13; forms of, 2 ; in soil, 174 ; nature of, 1; pure culture of, 19 ; reproduction of, 3 ; size of, 3 ; structure of, 2 .

Barn air, 33.

Bitter milk, 61.

Black leg, 104.

Butter, 65; deterioration of, 70 ; flavor of, 65 ; moldy, 72; sour-cream, 65; $s$ w e e tcream, 65 ; undesirable flavor in, 71.

Cabbage rot, 237.

Calcium, 182.

Canning, preservation of foods by, 231.
Carbon, cycle of, 181.

Carbolic acid, 168.

Cellulose digestion of, 208.

Certified milk, 83.

Cheese, 73; Cammembert, 80: Gorgonzola, 79 ; Limburger, 80 ; ripening of, 75 ; Roquefort, 79; Stilton, 79; Swiss, 78 ; types of, 73.

Chicago, rules for production of milk, 85 .

Chicken cholera, 157.

Cold, effect on bacteria, 10; preservation of foods by, 232.

Colored milk, 62.

Copper sulphate, 169.

Corn stalk disease, 109.

Corrosive sublimate, 169.

Cows, cleaning of, 28 ; clipping . of, 28 ; tuberculosis of, 39.

Cow pox, 146.

Cow stalls, 27.

Cream, ripening of, $66,69$.

Cresol, 168.

Culture, media, 15.

Denitrification, 190.

Diphtheria, bacteria of in milk, 40 ; of fowls, 159.

Dirt in milk, 26.

Disinfectants, 12.

Disinfection, 165.

Dístemper of dogs, 163 ; of horses, 163.

Drying, preservation of foods by, 225.

Eggs, preservation of, 232. 
Factory by-products, 31 .

Farcy, 129.

Farm separators, 31 .

Feed, effect of on bacteria in milk, 34 .

Ferrous sulphate, 169.

Fermentation of milk, 53 .

Fire blight, 236.

Foods, preservation of, 225 ; preservation of by drying, 225; preservation of by salting, 227.

Foot and mouth disease, 162.

Foot rot of sheep, 162.

Fore milk, 25.

Formaldehyde, 169.

Fowl, cholera of, 157; diseases of, 157; roup of, 159 ; tuberculosis of, 126; typhoid, 159.

Fungi, 1.

Immunity, natural, 95; artificial, 95, 102.

Intestines, bacteria in, 14 .

Intestinal diseases, caused by milk, 42.

Garget, 144.

Germicides, 12.

Glanders, 127; diagnosis of, 130.

Gorgonzola cheese, 79.

Heat, effect on bacteria, 11.

Hemorrhagic septicemia, 107.

Hog cholera, 151; prevention of, 154.

Hogs, diseases of, 151; tuberculosis of, 125.

Horses, distemper of, 163.

Hydrophobia, 136.

Lactic acid bacteria, 54 .

Leguminous plants, 198.

Lesions of disease, 96 .

Life in soil, 177.

Limburger cheese, 80.

Lime, 167.

Lumpy jaw, 142.
Mallein test, 130.

Mammitis, 144.

Manures, bacteria in, 207; decomposition of, 209; fire fanging of, 211; losses from, 210; in milk, 26.

Market milk, 82.

Mastitis, 144.

Melon wilt, 238.

Microscope, 20.

Milk, abnormal fermentation of, 57; aeration of, 48 ; alcoholic fermentation of, 60 ; bacteria in, 90 ; bitter, 61 ; care of, 89; certified, 83 ; clarifying of, 46; colored, 62 ; commissions, 83 ; condensed, 52; contamination of, 23 ; cooling of, 46 ; disease-producing bacteria in, 38; filtering of, 45; gassy fermentation of, 56 ; house, 37; market, 82; palls, 28; pasteurization of, 49 ; polsoned, 43; preservation of, 44; slimy, 58; souring of, 53 ; straining of, 44 ; tubercle bacteria in, 39 ; utensils, contamination from, 29 ; utensils, washing of, 32 .

Milker, contamination of milk from, 34 .

Milking, 88 .

Minerals, action of bacteria on, 182.

Nitrification, 187; conditions favoring, 188.

Nitrogen, conservation of, 192 ; fixation of, 196, 204.

Nodular disease, 126.

Nodules on legumes, 199.

Odors, absorption by butter, 72 ;

by milk, 36 .

Organic matter, decomposition of, 178 .

Parasitic bacteria, 7 .

Pasteurization, 49, 87; of cream, 68. 
Pathogenic bacteria, spread of, 95.

Pear blight, 236.

Period of incubation, 96 .

Pickles, 228.

Phosphorous, 182.

Plants, bacterial diseases of, 235; leguminous, 198.

Plant food, 171.

Poll evil, 162.

Potassium, 185.

Preservatives. 12.

Rabies, 134; diagnosis of, 139; prevention of, 138; symptoms, 135.

Roquefort cheese, 79 .

Roup, 159.

Salting foods, 227.

Saprophytic bacteria, 6 .

Septic tank, 220.

Septicemia, 107.

Sewage, disposal, 219 ; purification, 219.

Silage, 229.

Slimy milk, 58.

Soll, bacteria in, 13, 174 ; inoculation of, 202.

Spores, 5, 58.

Stable, disinfection of, 169.

.Starters, home-made, 66 ; pureculture, 68.

Sterilization, 16.
Stilton cheese, 79.

Sugar, preservation of foods by, 227.

Sulphur, 185.

Sweet curdling of milk, 57.

Swine plague, 156.

Swiss cheese, 78.

Symptomatic anthrax, 104.

Temperature, of cows, 120 ; effect on bacterial growth, 9 .

Tetanus, 131.

Transmissible diseases, 88, 92. Tuberculosis, 86, 110; diagnosis of, 118; distribution of, 110; of fowls, 126; of hogs, 125 ; symptoms of, 117.

Tuberculin test, 118.

Typhoid fever, bacteria of in milk, 40; of fowls, 159.

Udder, contamination of milk from, 24.

Utensils, milk, 89 .

Vinegar, 233.

Water, 90 ; bacteria in, 13 ; disease-producing bacteria in, 215.

Water glass, 232.

White scours, 161.

Wisconsin curd test, 63.

Yeasts, 60 .

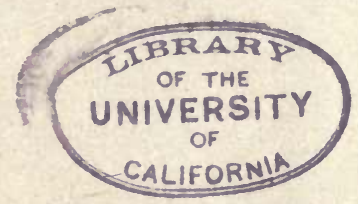




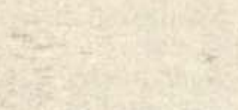


- 


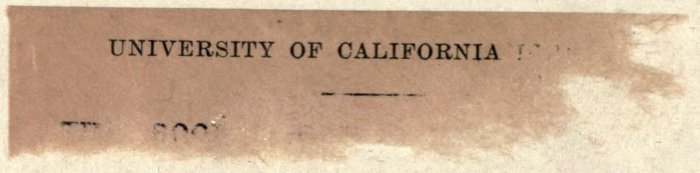




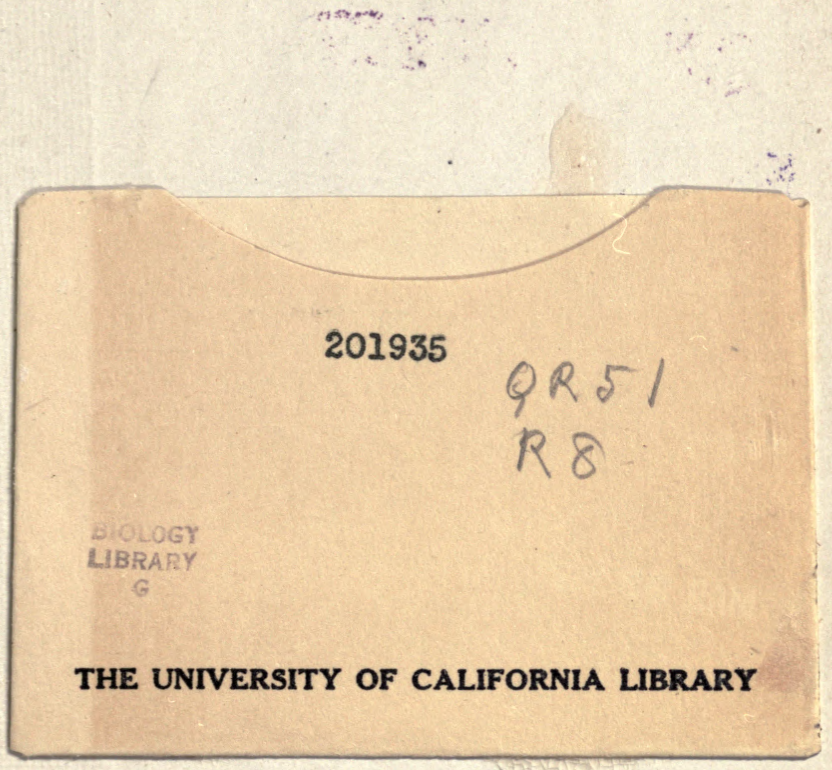


(n)

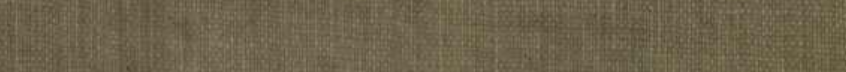
3. S.

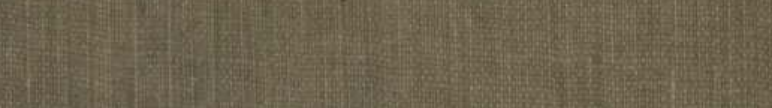

W (2)

f5. \begin{tabular}{|c|c|c|c|}
\hline &
\end{tabular} (3)

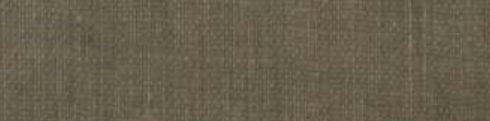
(5) 